\title{
Co-Housing+: \\ Towards a Greater Urban Community in Toronto
}

\author{
by \\ Maryam Bashardoust Tajali \\ A thesis submitted to the Faculty of Graduate and Postdoctoral Affairs \\ in partial fulfillment of the requirements for the degree of \\ Master of Architecture \\ Carleton University \\ Ottawa, Ontario \\ (C) 2015, Maryam Bashardoust Tajali
}




\begin{abstract}
This thesis grew from understanding the present common values of today's contemporary society, where people are less unified and prefer their secluded private realm showing diminished interest in integrating with the public sphere. The significance of social values and the benefits of being and living with others are lost to many societies impacted by the consumer culture. The research focuses on the enduring patterns of social relations and the design aspects of the well-established cohousing model in order attain the desired sense of belonging in the proposed design. The thesis proposes co-housing+, a mixed-use community-oriented residential complex in Toronto, which is designed to promote a balanced private and public life for the inhabitants, creating an urban community.
\end{abstract}




\section{Acknowledgments}

I would like to express my sincere gratitude to my advisor Dr. Federica Goffi, whose proficiency, knowledge, and understanding has been invaluable to my graduate experience. I appreciate her insights, guidance, and encouragement throughout my research. I am very grateful for her support that helped me achieve this level of accomplishment.

I would also like to express my special appreciation to all advisory committee members for their intellectual comments and valuable observations. Thank you for letting my defense become a remarkable moment, this is truly an honor for me that my hard work was recognized and appreciated by highly valued professionals.

I thank Carleton University and Azrieli School of Architecture \& Urbanism for the great opportunity to be educated and insightful in pursuing my true passion. I appreciate all my teachers for allowing me to become educated professionally and to grow intellectually throughout my graduate studies. I would also like to sincerely thank Professor Yvan Cazabon

who has been a great mentor for me. I would like to extend my thanks to Professor Paul Holmquist for his insightful lessons and inspiration deepening my interest about other aspects of Architectural world.

I am eternally grateful to my father, whose guidance lid up my way, taught me honorable values, and filled me up with encouragement in my life. I am very much grateful and thankful to my mother who endlessly supported me in my life, encouraged me every day, and had always been there for me with understanding and selflessness. I am truly appreciative to my sister, Soheila, my best friend, for all her support, guidance, and compassion that helped me achieve all my successes all my life. I am also deeply thankful to my brothers, Siamak and Masoud, for their care, guidance, support, and encouragement all through my way here. I feel so blessed to have such a loving family and grateful for their support and encouragement every step along the way to where I am today. Words cannot express my appreciation to my supportive family who helped me accomplish all my academic and personal success. 
To my beloved parents, Aghdas and Soheil the oasis of wisdom and love to whom all my successes belong to...

In loving memory of my father, Soheil 


\section{Table of Contents}

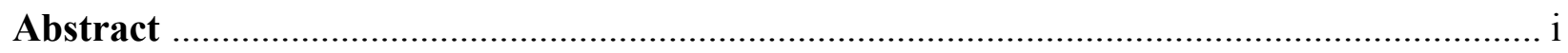

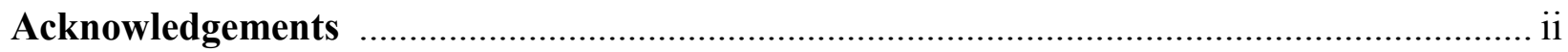

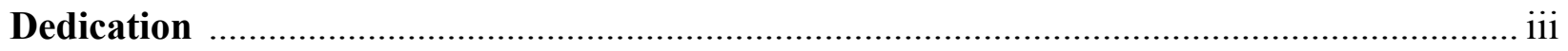

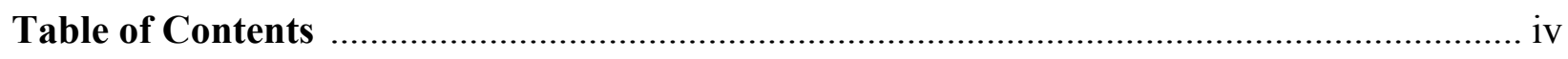

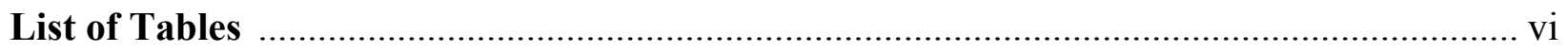

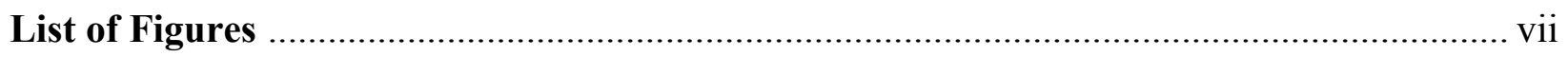

Section I: Theoretical Research

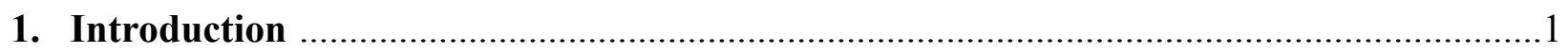

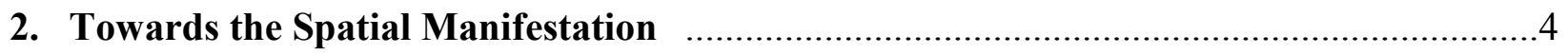

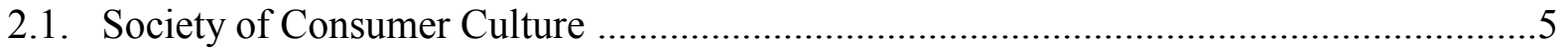

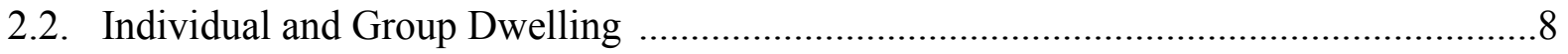

2.3. The Need for a Sense of Belonging .................................................................... 10

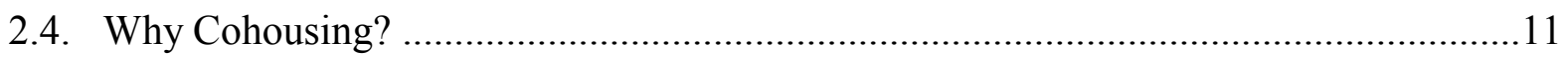

\section{Section II: Literature Review}

3. Architecture for Community: A Collective Expression ............................................12

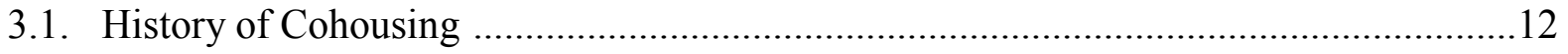

3.2. Design and Principles of Private Residential Communities .....................................14

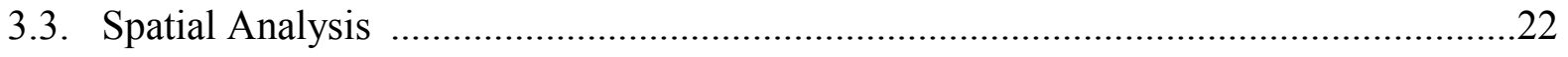

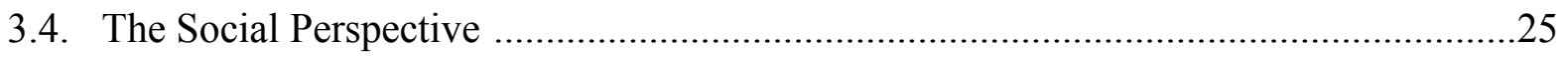

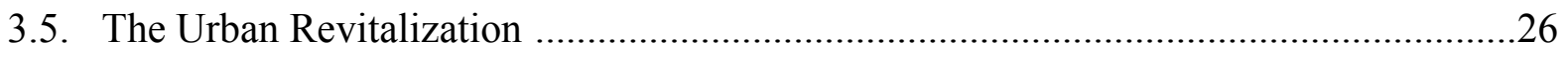

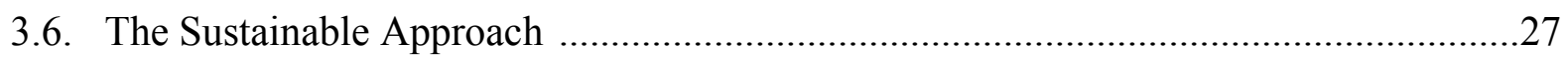




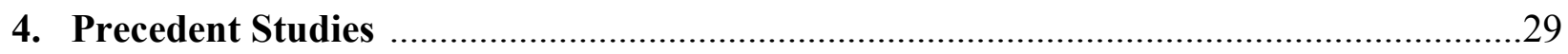

4.1. Comparison of Housing Typologies in Canada ....................................................29

4.2. Residential Developments in Toronto .............................................................................35

4.3. Examples of Successful Community-oriented Housing Projects ...............................37

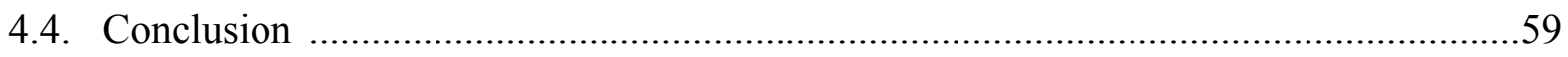

\section{Section III: Design Exploration}

5. Design Methodology of a Community-oriented Residential Complex ........................61

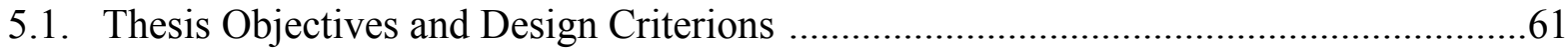

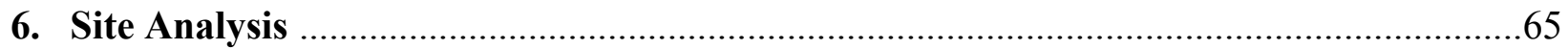

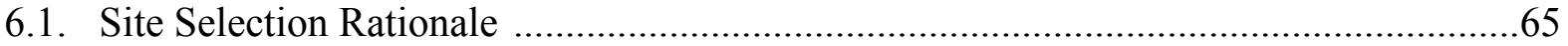

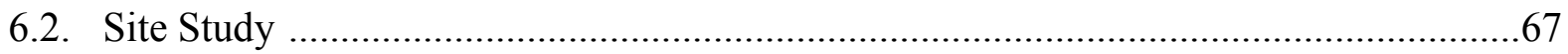

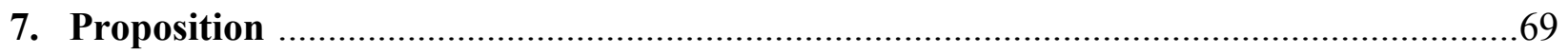

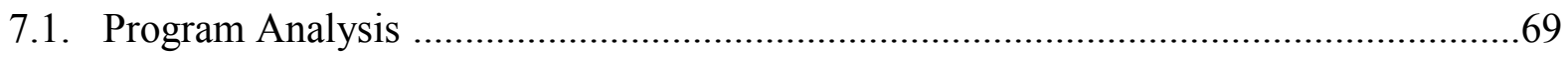

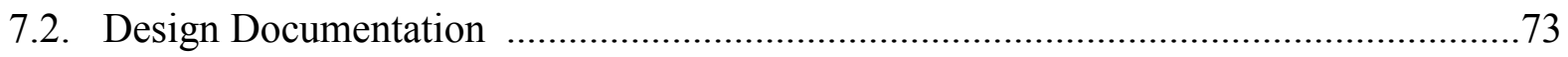

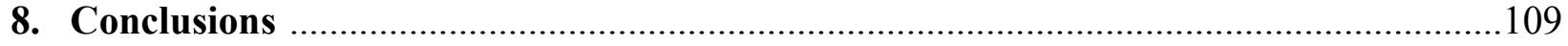

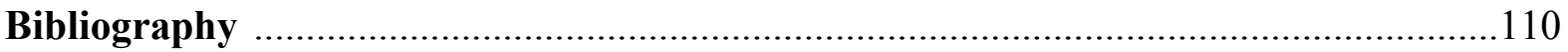




\section{List of Tables}

Table 1: A comparison of cohousing vs. condominium

vs. co-operative residential type

Table 2: Cohousing communities in Canada

Table 3: The spatial analysis of the proposed designed community compared to the studied cohousing developments

Table 4: Overall characteristics of the proposed community-oriented residential complex derived from the cohousing model (refer to Table 1) 64

Table 5: Program details chart .70

Table 6: Dwelling units type, variation (with the total number of unit type of that specific variation), and floor area analysis 


\section{List of Figures}

Figure 1: Diagram defining the philosophy of the theory (from general to specific) and the methodology of the design (from details to whole)

Figure 2: ARC Condos, Toronto, Canada

Figure 3: Aqua Tower, Chicago, United States ………........................................................

Figure 4: Conceptual framework to define the notion of dwelling .............................................

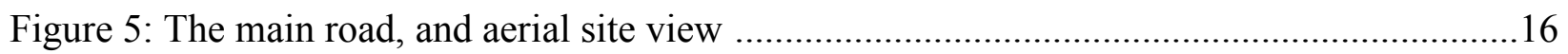

Figure 6: A house in Sharingwood community and children play area .......................................16

Figure 7: Cohousing site plans: (a) the courtyard, (b) the village type, (c) the forum type, (d) the pedestrian street, (e) the hybrid of courtyard and pedestrian street, (f) the single building with an internal atrium functioning as the pedestrian street

Figure 8: Site plans .39

Figure 9: Cohousing pedestrian street (left)

Figure 10: The common area (right)

Figure 11: The village square (left), and the historic market (right)

Figure 12: Ground floor plan

Figure 13: Site section (Drawing by Pyatok \& Assoc.)

Figure 14: Doyle Street cohousing in 1992 when completed

Figure 15: Community view from the courtyard

Figure 16: Interiors of a unit reflecting the character of the old building with the brick wall and the personal taste of the residents .45

Figure 17: Neighbors gathering in Spring 2011 .45 
Figure 18: The ground floor plan

Figure 19: Section of the building showing the lower and upper units, lofts and mezzanine make use of the double height ceiling

Figure 20: Site plan

Figure 21: Glass covered pedestrian street .50

Figure 22: Outdoor gardening (left), community gathering (right) .50

Figure 23: Quayside Village cohousing front view .53

Figure 24: Residential units view (top) .54

Figure 25: Shared courtyard (left) .54

Figure 26: Community life .55

Figure 27: Townhome interior view .55

Figure 28: Common spaces and gardens layout .55

Figure 29: Terra Firma cohousing site front view from Drummond Street showing two townhouses with the infill common house addition .58

Figure 30: Cohousing design aspects consideration with regards to section 3.2. in order to design an architectural edifice that promotes community

Figure 31: Site view illustrating the urban block with the park and the tennis club, the major route, and the major and minor close streets .66

Figure 32: Site analysis showing the facilities and services in the close proximity of the site

Figure 33: Initial sketches developing the complex from the public ground floor to the private residential units, the shared spaces are placed withinthe residents' main circulation paths

Figure 34: Arial view of co-housing+ within its context

Figure 35: Building form top view showing the access points 
Figure 36: Building form axonometric view showing the notion of the park greenery extended in to the courtyard + the courtyard extended out to the park .79

Figure 37: Northwest elevation view .80

Figure 38: Schematic design demonstrating the layout of the public spaces at the ground level .81

Figure 39: Ground level floor plan .82

Figure 40: Sectional axonometric view illustrating public and semi-private spaces around the courtyard .84

Figure 41: Interior courtyard showing a public event for residents and surrounding neighborhood .85

Figure 42: Interior courtyard lounge area with greenery and water features ............................86

Figure 43: View of the exterior courtyard and the café .87

Figure 44: Schematic design demonstrating the arrangement of green spaces within the building complex .88

Figure 45: Schematic design demonstrating the layout of the semi-private spaces

Figure 46: Underground parking and storage space floor plan..... .90

Figure 47: Second level floor plan .91

Figure 48: Third level floor plan .92

Figure 49: Fourth level floor plan .93

Figure 50: Courtyard view illustrating the physical connectivity in-between spaces and the visual lines of the residents

Figure 51: Common dining area with a view to the second level connecting pathway .96

Figure 52: Schematic design demonstrating the layout of the private spaces . .98

Figure 53: Typical floor plan of one of the variations of a 1-bedroom, a 2-bedroom, and a duplex 3-bedroom apartments 100 
Figure 54: Sectional drawing showing the sense of porosity in and between spaces

Figure 55: Sectional drawing illustrating pragmatic intent within the urban context

Figure 56: Circulation diagram showing pathways in public, semi-private, and private spaces 104

Figure 57: Overall axonometric view of co-housing+

Figure 58: The building entrance from the park where community is extended to the surrounding neighborhood 


\section{Section I: Theoretical Research}

\section{Introduction}

The special aura of a building is perceived when a building sustains both physical and psychological aspects of inhabitants needs. To dwell requires one to understand the relationship between the inhabitant and the environment. Dwelling, as Heidegger stated, requires establishing a place by creating physical boundaries and experiencing it in time. ${ }^{1}$ Inhabitation occurs through the engagement of residents with a space and most notably in the interactions amongst residents. Dwelling comes to existence through inhabitation in the private sphere and becomes meaningful through interactions with one another in the public realm. ${ }^{2}$ Thus, a key question would be how is inhabitation experienced through a specific design for creating a sense of belonging? And in the broader context, where can we, as individuals within a society, find a real sense of belonging to a community?

In the late $20^{\text {th }}$ century, the modern movement in architecture witnessed the emergence of a cultural shift towards luxury and consumer culture in the Western world. Modernism evolution over the years lead to the development of iconic and avant-garde buildings including high-rise condominium buildings and apartment towers which became the

\footnotetext{
${ }^{1}$ Harries, The Ethical Function of Architecture, 223-224

${ }^{2}$ Ibid., 152-166
} 
new way to live within large urban centers. ${ }^{3}$ In these building types, the private realm notably has been isolated from the public sphere, affecting the sense of community. Consumerism society has transformed the ideal place to live from a shared public community to personal private homes. In our present time, private homes can be described as places where individual consumption is central to the lifestyle. So, our lifestyle has changed along with our choice of urban dwelling types resulting in a paradoxical contraposition with our basic human need for interactions with other people. ${ }^{4}$ Thereby, as the population increases and the architectural development intensifies, the urban environment in the cities is consumed further, and in a way that the sense of community declines.

Considering that dwelling comes to existence through interactions with others, Harries states that "the problem of architecture is inevitably also the problem of community". ${ }^{5}$ In today's complex life, architecture should do its share to return individuals to a whole, to a community, through community-oriented approaches. A work of architecture should be "essentially a functional building with an added aesthetic component", functionality that considers both private and public life of inhabitants. ${ }^{6}$ This thesis focuses on merging the need for residential architecture through a balance of spaces for the personal life of the residents in the private sphere with a sense of community created by fostering social interactions in the public sphere, enhancing the urban community. It explores the concept of dwelling with regards to essential human values: social interactions and sense of belonging. This thesis proposes a community

\footnotetext{
${ }^{3}$ Examples include Guggenheim Museum in New York by Frank Lloyd Wright (1959), Marina City mixed-use residential/commercial high-rise building complex in Chicago by Bertrand Goldberg (1964), 860-880 Lake Shore Drive apartment towers in Chicago by Ludwig Mies van der Rohe (1951), and Edificio Copan high-rise residential building in Sao Paulo, Brazil, by Oscar Niemeyer (1966)

${ }^{4}$ Arendt, The Human Condition, IX

${ }^{5}$ Harries, The Ethical Function of Architecture, 13

${ }^{6}$ Harries, The Ethical Function of Architecture, 26
} 
oriented approach through the design of private, semi-private, and public spaces within a cohousing residence. Figure 1 illustrates schematically the theoretical investigation going from surface to substance, and the design proposition and process developed from interior to exterior for the construction of an urban residential community.
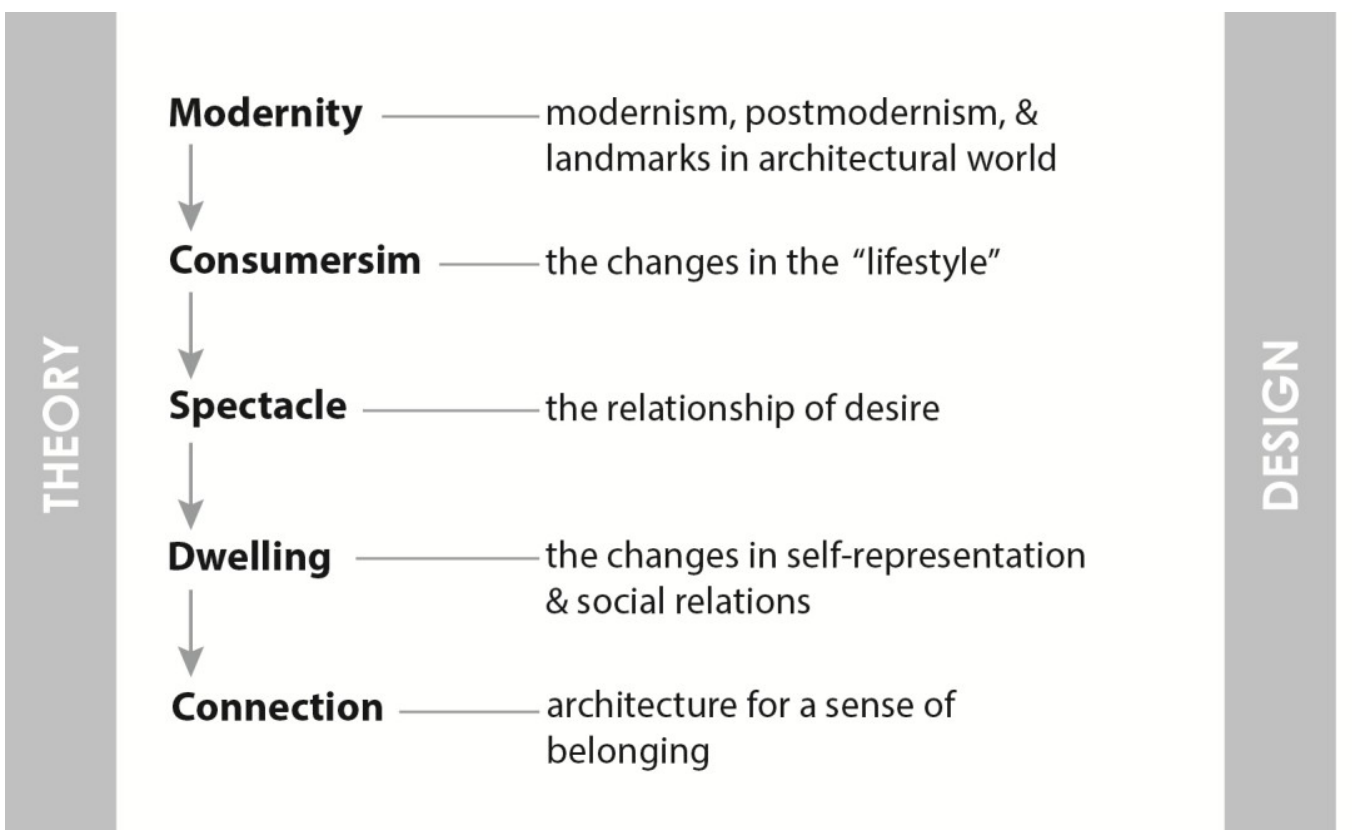
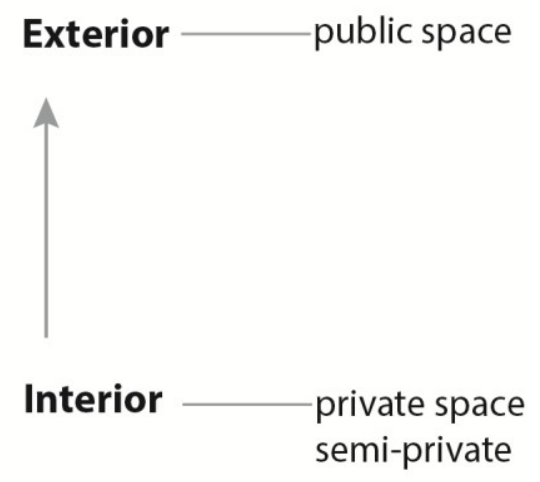

Figure 1: Diagram defining the philosophy of the theory (from general to specific) and the methodology of the design (from details to whole) 


\section{Towards the Spatial Manifestation}

With no doubt, the way of dwelling in our contemporary time should be analyzed considering various causes that lead to its present condition. It can be stated that the decline in the sense of community is the outcome of a hierarchy of causes and symptoms that begins with modernity. Consumer culture and individualism are the main basis from which spectacle appeared and human dwelling changed. Consumerism became the leading force forming the way people live in the private realm and create their identity in the public realm. In contemporary Western society, spectacle serves to increase the sense of individualism. The technological advancement, the global mass media, the celebrity culture, and the aestheticization of lifestyle are all social forces affecting our lives. In the world of architecture, residential landmark buildings are a symptom of modern social and cultural changes. As a result, a loss of the sense of community both in the private realm and the public sphere shows how our notion of dwelling has changed. At the present time, individuals have the preference of the way they want to live such as in private apartments in high-rise condominium buildings or in private homes in inner city neighborhoods, however the more trendy solution is the former rather than the latter. This chapter presents the theoretical research done for the need for a sense of community. 


\subsection{Society of Consumer Culture}

The dilemma of modernity in relation to the condition of the urban dweller can be analyzed when considering the separation it has caused of the individual from the community in present culture and society through architecture. Consumerism became the principle mode of self-expression; turning into a common language expressing a desire for commodity not just pure necessity. ${ }^{7}$ In today's modern society, spectacle is in fact "the social relation among people that is mediated by images". 8 As Debord puts it in his foundational work, the public is no longer unified rather divided by spectacle. Social life is entirely dominated by commodities and lifestyle has become a mode of consumption. ${ }^{9}$ The changes in the life style, reduced "being" into a state of "having", and having into "appearing". ${ }^{10}$

The overwhelming presence of images in contemporary culture is critical, and in architecture as central means by which urban settings are now formed. In a consumer society, spectacle becomes a main common visual and spatial experience the public shares, thus resulting in a total commodification of architecture reduced to a formal approach to design. ${ }^{11}$ The creation of unique landmark architectural works is considered advantageous in terms of fame and capital for architects and hosting cities. However, the social experience of inhabitants is often not taken into consideration. This is an important design element in the world of residential architecture.

\footnotetext{
7 Debord, Society of the Spectacle, 19

8 Ibid., 1

9 Ibid., 20

10 Ibid., 3-4

11 Hartoonian, Architecture and Spectacle: A Critique, 5-29
} 
In recent decades, the rise of condominium buildings in Toronto has turned the city into the largest residential market in North America. ${ }^{12}$ The advertisements of residential high-rise condominiums generally concentrate on their public image linking them with high-end design and luxurious lifestyle. ARC Condos (2009) a fifteen storey building in Toronto, is an interesting example of a high-rise residential landmark. It has an arc-like shape designed for a sophisticated condominium living located in a vibrant neighborhood close to a luxury shopping mall. However, the building's public spaces are not designed to foster residents' interactions. Like other high-rise condominiums, public amenities are distant from the main circulation paths and are used by individual households privately, rather than by all residents publicly. Another example is the Aqua Tower in Chicago (2009), an 82-story mixed-use residential skyscraper known for its undulating façade and for being the first skyscraper designed by a female architect. ${ }^{13}$ It is certainly designed to be accepted by the public at large as a landmark building but interactions among residents are limited in the existing public spaces. For instance the public balconies are claimed to be the social spaces, but they are not quite working in those terms, simply because of the height of the building and the small size of the balconies.

Therefore, in general, the sculptural quality of the named buildings does not add to the social experience of the inhabitants. But the personal status one can gain by living in luxurious residential properties or inhabiting commercial spaces is strong enough to fit individuals into a higher class in the consumerist society. To live in such places is indeed to fulfill the desire for a certain appeal, to have the satisfaction of living in a place that reveals status through the

\footnotetext{
12 Wong, Tony. "Condo Sales Booming"

13 The award-winning tower is designed by a team led by Jeanne Gang.
} 
building's own image. All this at the expense of the loss of human values of interaction and belonging, and consequently the loss of the sense of community.

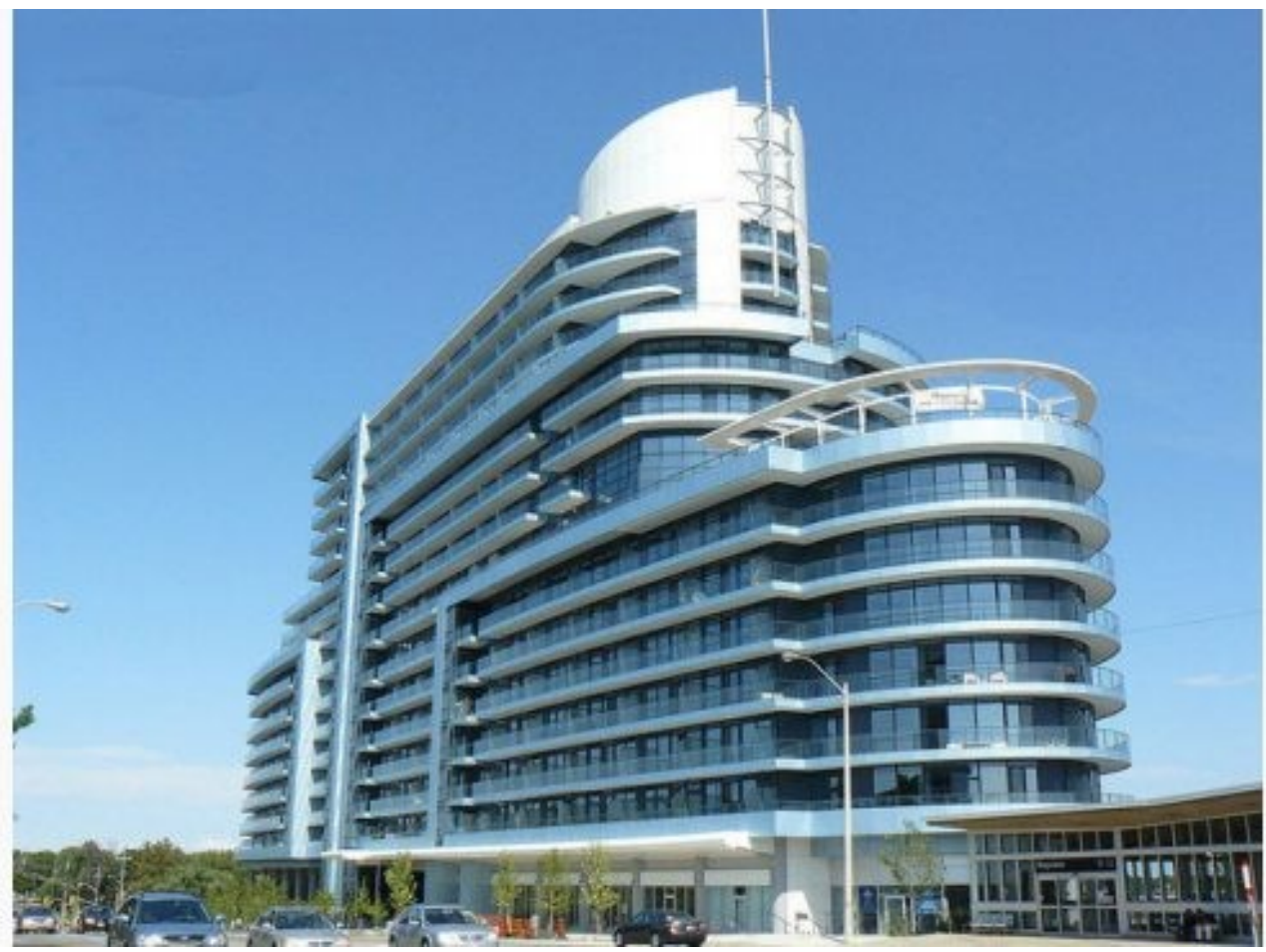

Figure 2: ARC Condos, Toronto, Canada. Image courtesy of Hume, Christopher. "Condo Critic: Hope Sails into the Suburbs"
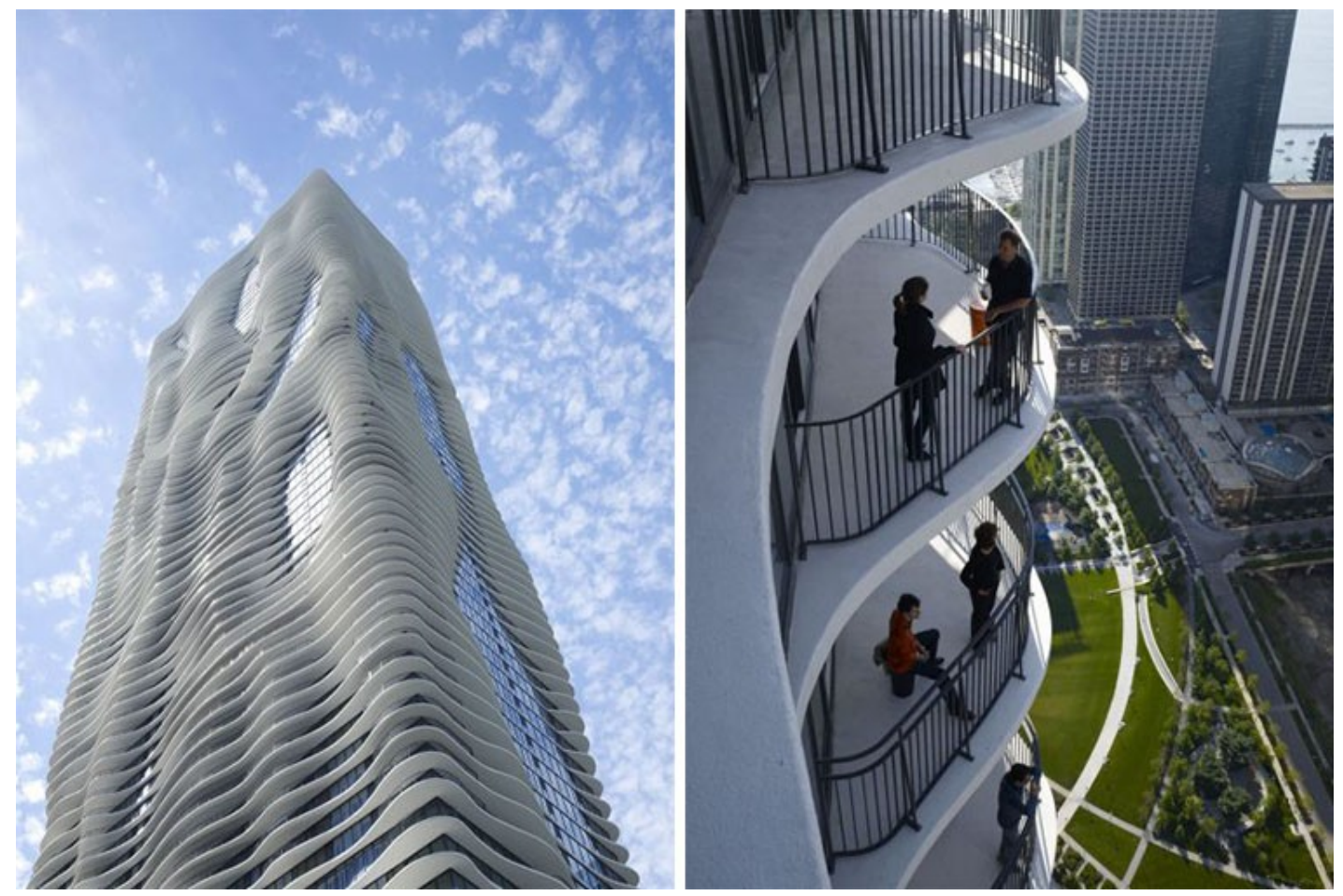

Figure 3: Aqua Tower, Chicago, United States. Image courtesy of Studio Gang Architects http://studiogang.net/work/2004/aqua 


\subsection{Individual and Group Dwelling}

The aestheticization of everyday life, as desire characterizes our mode of consumption, poses problems for the notion of dwelling, being a threat to our own human essence. But how can we further explain dwelling? In general, dwelling includes all the simple yet necessary everyday activates like cooking, playing, reading, loving, and etc. Dwelling or inhabiting is then inseparable from the inhabitant and the environment and in Harries's words "building allows for dwelling by granting a sense of place". ${ }^{14}$ Also as Heidegger reminds us there is a distinction between genuine dwelling from mere residing in a building. ${ }^{15}$ Hence, it can be stated that dwelling is defined by its place of occurrence and by its functions.

The place of occurrence is simply the physical space wherein meanings take place, therefore it is directly connected to the private and public realms. For instance creating one's identity such as self-representation in private life and forming regulations of social relations in public life. ${ }^{16}$ Therefore, dwelling has different meanings with regards to individuals and communities. It means to have a private world: to be oneself. It also involves meeting others, interacting, exchanging ideas, or feelings: to participate. Furthermore, it includes accepting a set of common values in the public sphere: to share. ${ }^{17}$

\footnotetext{
14 Harries, The Ethical Function of Architecture, 154

15 Heidegger, "Building, Dwelling, Thinking", Poetry, Language, Thought, 146

16 Kaiser, Fuhrer, "Dwelling: Speaking of an Unnoticed Universal Language", 227 Meesters, The Meaning of Activities in the Dwelling and Residential Environment: a Structural Approach in People-Environment Relations, 24-25

17 King, Private Dwelling: Contemplating the Use of Housing, 22-23
} 


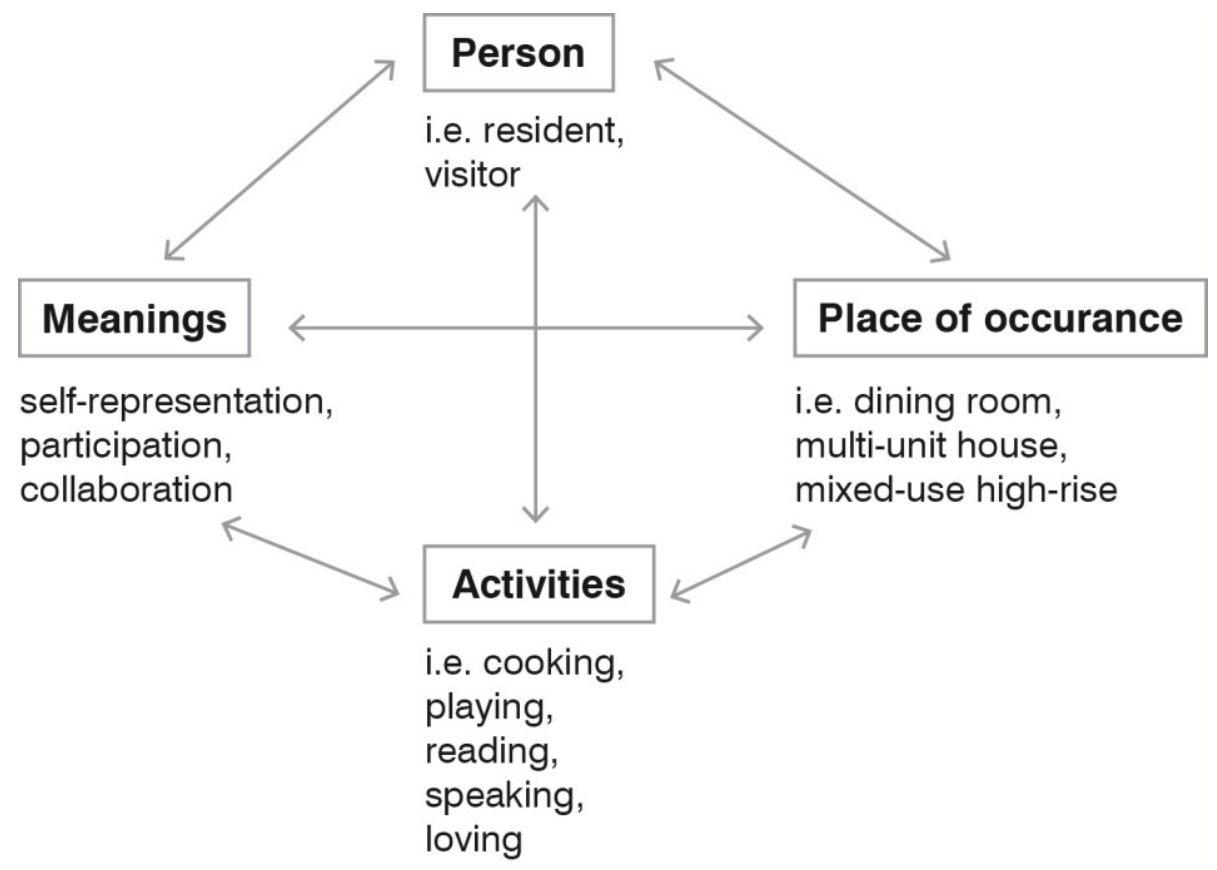

Figure 4: Conceptual framework to define the notion of dwelling. From Meesters, The Meaning of Activities in the Dwelling and Residential Environment: a Structural Approach in People-Environment Relations, 25

Dwelling then can be recognized to be an important connection between the public and private realms, since "it identifies the individual with the community". ${ }^{18}$ All the meanings of dwelling are interrelated and when a real sense of dwelling is achieved the very sense of belonging and participation may be achieved.

${ }^{18}$ King, Private Dwelling: Contemplating the Use of Housing, 22 


\subsection{The Need for a Sense of Belonging}

The advancement of technology slowly transforms humans into increasingly displaced individuals, we no longer understand ourselves as the members of a community. Architecture should recognize that our life in the world is essentially a life with others and thus all buildings have a social significance. ${ }^{19}$ With the vast social and cultural changes in recent decades, the impact of these changes on individuals' lifestyle cannot be neglected. In the consumer capitalism society, individuals prefer to be identified by the meaningful values that are offered by individualism such as independence and self-reliance. Framed within this perspective, people take a part in society but towards their own personal interests. What matters are personal achievements, apart from community and society. The separation from social contacts in the frameworks of consumerism and individualism, forces the development of private spaces rather than shared places. The lack of semi-private or public spaces from which community forms has highly decreased the social interactions that define our well-being. Even though the density of urban environments has increased along with the social and cultural changes, nowadays many people live far away from family members and others they can rely on. There is certainly a need for places providing a sense of community and belonging. This can be offered fostering designs that facilitate social interactions in the private realm of residents opening spaces up to the public sphere in urban environments.

${ }^{19}$ Harries, The Ethical Function of Architecture, 270-292 


\subsection{Why Cohousing?}

By some means, the architectural solution to separation from of community that exists in today's contemporary societies can be living in "collaborative housing" communities, as Fromm refers to them. ${ }^{20}$ They promote the well-being of residents through collaborations and relations. Cohousing is designed to increase the social interaction among inhabitants for instance residents can share meals, meet regularly, discuss community issues, and manage their collaborative places. This residential model has demonstrated a successful approach to address the lack of social contacts and the separation from community occurring due to an extensive consumer culture and suburbanization. It provides a balanced private life and community life just where we need to dwell, at "home".

${ }^{20}$ Fromm, "Seeding Community: Collaborative Housing as a Strategy for Social and Neighborhood Repair", 364 


\section{Section II: Literature Review}

\section{Architecture for Community: A Collective Expression}

\subsection{History of Cohousing}

As it was discussed earlier, society has changed from the collective public to private individualism. Cohousing was the result of the collective movement occurred in 1960s where people lived together sharing a common life and common interests. ${ }^{21}$ Members of collective communities often hold common social and political ideas and put special effort in creating their own society. Although cohousing has been influenced by the communal approach in housing, it has major differences with this movement. One main distinction is cohousing residents desire to live within the existing society while having privacy. Moreover, these communities are not entirely communal. Inhabitants share many values but are not united by a particular ideology. The idea of collaborative housing started in Europe in the 1970s when a group of professional families realized that their families were so consumed with a busy life that they could not share much time with others and were searching for better childcare. The types of housing they could afford was either in isolated suburbia or in dense urban areas. The result was "Saettedammen", the first collaborative development built in 1972 in Denmark. The Danish cohousing community

\footnotetext{
${ }^{21}$ Fromm, Collaborative Communities: Cohousing, Central Living, and Other New Forms of Housing with Shared Facilities, 15
} 
has private houses with common facilities in a separate common house, a residential community developed based on common social activities: cultural events and common celebrations. Cohousing can be distinguished from collaborative, collective, and communal standpoints in terms of the housing objectives. Its collaborative aspect is interpreted as creating collaboration between inhabitants; the collective side refers to the collective organization of services, while the communal aspect refers to the design of a residential type that creates community. ${ }^{22}$

From the 1960s, although the modern cohousing structure initiated because of economic motives, it then mostly spread through most of the countries in North Europe. By 1988, the concept started to propagate in the United States and then from 1996 also in Canada. ${ }^{23}$ Cohousing has evolved over the years worldwide and has become an attractive residential type to intergenerational families. It offers opportunities to experience community where there is home. Although the interpretations of cohousing are known to be related to local conditions, the international connections among the cohousing projects have had a considerable impact on the exchange of ideas making it an international movement. It has been interpreted as an effective solution to the social and environmental problems that today's contemporary society faces, since it reinforces collaborative relationships into the urban context. ${ }^{24}$ The elements of collaborative housing are derived from "Saettedammen" as the primary model for this relatively new housing typology: common facilities such as play areas and meeting rooms, private dwellings, resident management, resident participation in the planning process, and design for social relation and

${ }^{22}$ Krokfors, "Co-Housing in Making", 309

${ }^{23}$ Scotthanson, Scotthanson, The Cohousing Handbook: Building a Palace for Community, 2-3

${ }^{24}$ Lietaert, "Cohousing's Relevance to Degrowth Theories", 576-580

Krokfors, "Co-Housing in Making", 309-313 
collaboration. $^{25}$ The design layout provides personal privacy that comes with private ownership, and shared community that exists within the semi-private and public spaces. ${ }^{26}$ It provides the sense of belonging of a private place through ownership and control along with the sense of belonging to a community where the semi-private spaces are used as informal collaborative places.

It also should be noted that even though there are many positive aspects about community-oriented lifestyle in cohousing, the critics of this type of housing have indicated some problematic issues that might have negative impacts on the urban environment. One problem with this type of communities can be stated as similarity of social class of the residents that exclude certain low-income groups. Moreover, lack of integration with surrounding neighborhoods is another aspect that might be present because of the physical separation in closed cohousing communities or the social relationship self-sufficiency that exist within their community. ${ }^{27}$ In the proposed design, theses problems are taken into consideration.

\subsection{Design and Principles of Private Residential Communities}

\section{The Physical Design}

In this housing type, every community-oriented residential development is designed in relation to its context. It is a pragmatic and flexible housing model developed according to the characteristics of the site and the requirements, preferences, and financial capacity of residents.

\footnotetext{
25 Fromm, Collaborative Communities: Cohousing, Central Living, and Other New Forms of Housing with Shared Facilities, 7-18

${ }^{26}$ Scotthanson, Scotthanson, The Cohousing Handbook: Building a Palace for Community, 2-3

27 Chiodelli, Baglione, "Living Together Privately: for a Cautious Reading of Cohousing", 27
} 
The site location is one of the most important factors for groups forming a community. It can be in urban, suburban, or rural contexts. It should be considered that the choice of location definitely affects the proximity of facilities and services, for instance shopping centers, schools, recreational centers, and parks. The suburban and rural developments provide a secure and healthy environment close to nature in less dense environments such as Sharingwood in Snohomish County and Nyland in Lafayette, USA. In contrast, the "inner-city" projects, as Meltzer refers to them in an article, whether based on reuse of existing buildings or new developments in vacant sites, are located in dense urban environments in which affordability is considered less important for residents than residing within "mainstream society" ${ }^{28}$ Examples of these urban communities in North America and Canada can be Doyle Street in Emeryville, Berkeley Cohousing in Berkeley, USA, and Terra Firma in Ottawa, Canada.

${ }^{28}$ Meltzer, Graham. "How Does Cohousing Create Sustainability?” 


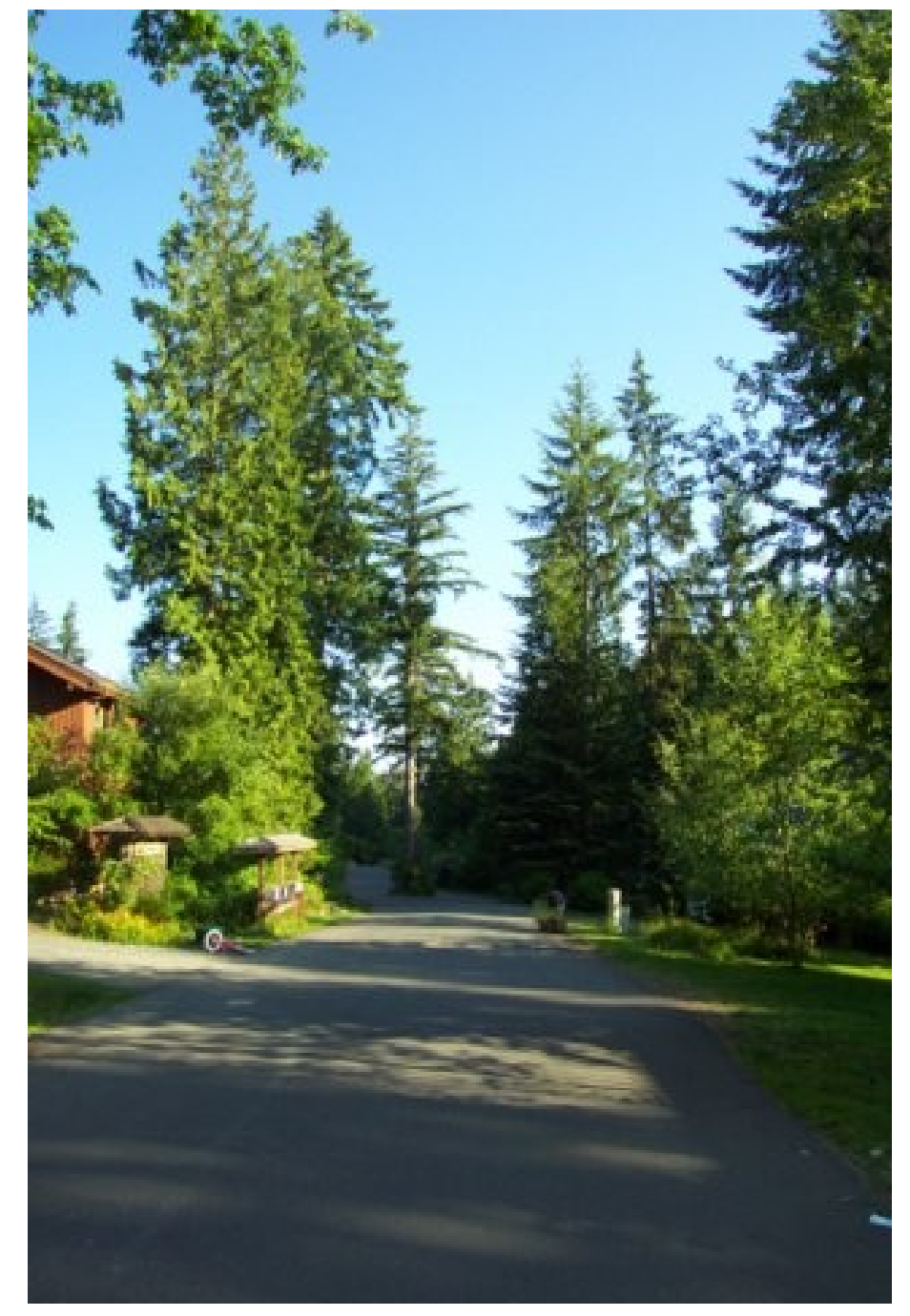

Figure 5: The main road, and aerial site view. Image courtesy of Sharingwood Cohousing Association http://sharingwood.org/photos.htm
Sharingwood Cohousing

Snohomish County, Washington, USA

Status: Completed

Established: 1999

Site: Rural

Site area: $161,874 \mathrm{~m}^{2}$

Common area: $204.38 \mathrm{~m}^{2}$

Development: Resident-led

Development: New lot-development

Tenure: Private ownership

Design: 28 houses, 1 common house

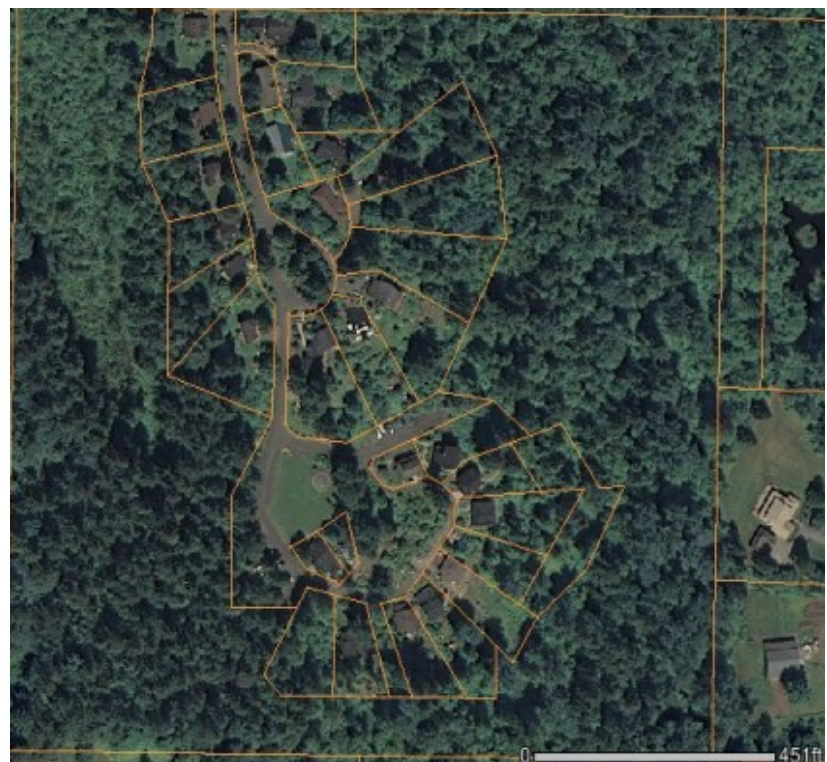

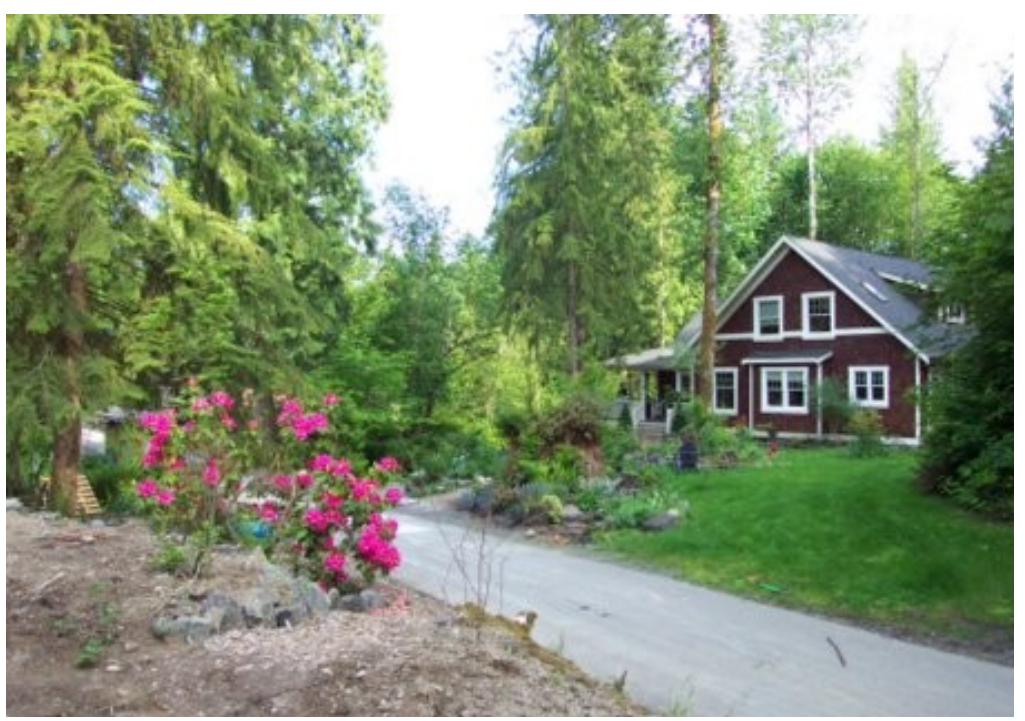

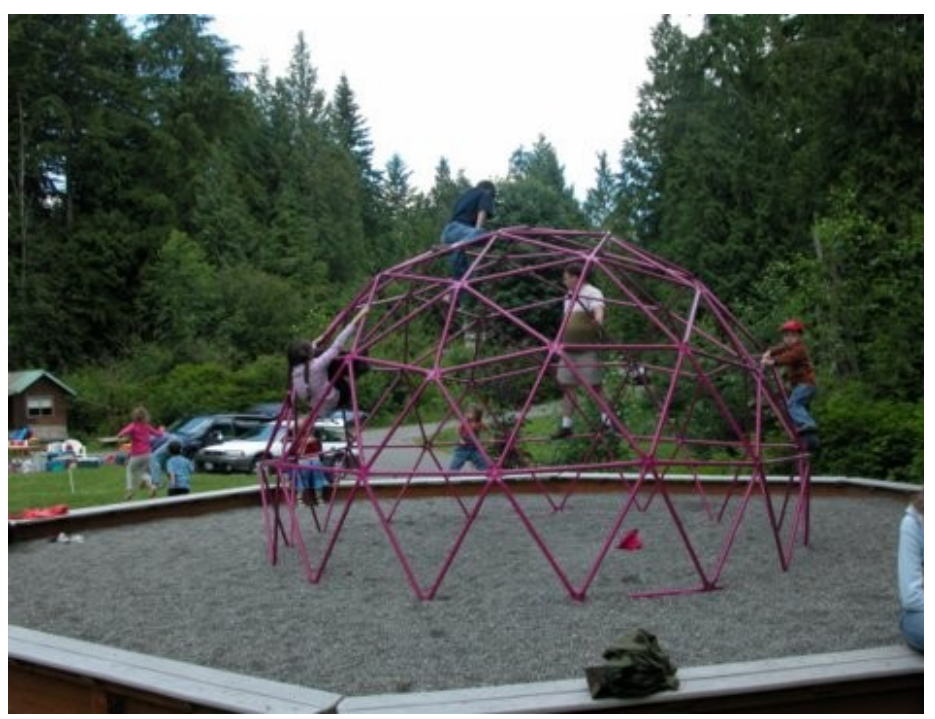

Figure 6: A house in Sharingwood community and children play area. Image courtesy of

Sharingwood Cohousing Association http://sharingwood.org/photos.htm 
Historically, cohousing communities have been designed, planned, and managed by homogenous community members. In North America, this model has evolved over the years with diverse approaches to the development and the recruitment process of residents including resident-led, partnership, and developer-led. ${ }^{29}$ Traditionally, this housing model can be categorized as a resident driven model where residents manage every aspect of the community project. ${ }^{30}$ This approach has been in low demand because of various potential problems such as time limitation, financial risk of owners, difficulties in financing the project, and complications with sites and developers. To overcome these issues, developers are more involved in other approaches to residential design, since they have the expertise of managing the finance and the development. In partnership approach, residents and developers cooperate with each other throughout the production process. The developer-led projects are produced entirely based on developers' decisions including site selection, financing the development, site planning, design, construction management, legal processes, marketing the project, and membership formation. ${ }^{31}$ The study of the two major works on cohousing, Fromm and McCamant and Durrett, present that cohousing is generally not tied to any particular size, design, or ownership structure, also emphasizing that residents' participation in design and development is alternative but recommended. ${ }^{32}$

The physical form of the residential units is usually compact and clustered townhouses, detached houses, or low-rise apartments depending on the site scale. The spatial orientation is

\footnotetext{
${ }^{29}$ Williams, "Designing Neighborhood for Social Interaction: The Case of Cohousing", 202

${ }^{30}$ Fromm, Collaborative Communities: Cohousing, Central Living, and Other New Forms of Housing with Shared Facilities, 10-12

31 Williams, "Predicting an American Future for Cohousing", 270-271

${ }^{32}$ Fromm, Collaborative Communities: Cohousing, Central Living, and Other New Forms of Housing with Shared Facilitie, 2

McCamant, Durrett, Creating Cohousing: Building Sustainable Communities, 16
} 
directed by important aspects of spatial connectivity, shared courtyard and walkways, pedestrian circulation, and community supervision. ${ }^{33}$ Hence, various spaces can be categorized based on the layout of the semi-private spaces in relation to private and public spaces such as dwellings' orientation around the central courtyard or internal pathway connection between dwellings and common spaces. ${ }^{34}$ Figure 7 demonstrates site layouts used to facilitate social interactions among inhabitants. $^{35}$

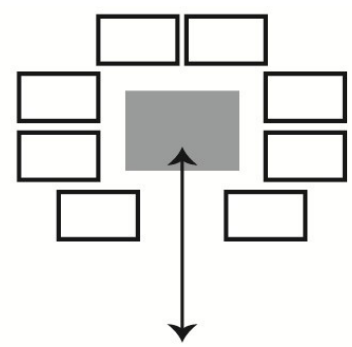

a

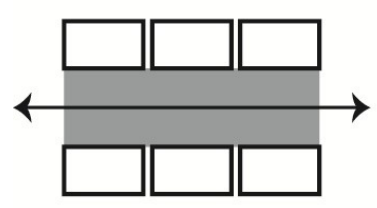

d

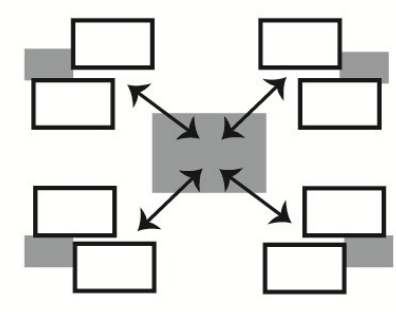

$\mathrm{b}$

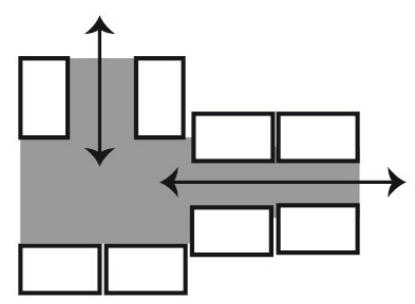

e

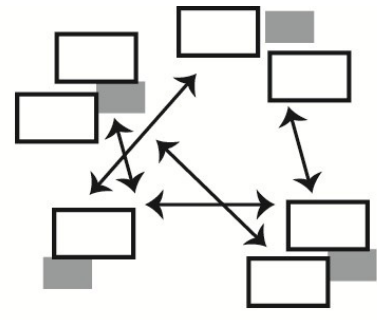

C

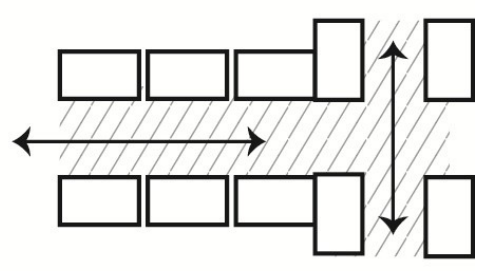

f

Figure 7: Cohousing site plans: (a) the courtyard, (b) the village type, (c) the forum type, (d) the pedestrian street, (e) the hybrid of courtyard and pedestrian street, (f) the single building with an internal atrium functioning as the pedestrian street. From Meltzer, Sustainable Community: Learning from the Cohousing Model, 5, and Helamaa, "The Extended Home: On Design Solutions for Community Oriented Housing", 74-79

33 Williams, "Designing Neighborhood for Social Interaction: The Case of Cohousing”, 203

34 Helamaa, "The Extended Home: On Design Solutions for Community Oriented Housing", 74-79

35 Ibid. Meltzer, Sustainable Community: Learning from the Cohousing Model, 4-5 


\section{The Principles}

Cohousing benefits from the coexistence of private residential spaces and public common spaces managed with a high degree of residents' participation. The quantity and quality of collective facilities are defined based on the values and needs of residents. ${ }^{36}$ The purpose of this model is to sustain privacy while sharing spaces. In general, all cohousing developments are defined encompassing the following characteristics: ${ }^{37}$

- Participatory process: the future residents of the community participate in the design and planning process in order to satisfy their requirements. However, some cases are initiated by the developers based on the spirit and principles of cohousing communities and/or for specific types of potential clients.

- Integrated design: the physical design and layout of the building should form a neighborhood that promotes a strong sense of community. The private dwellings typically are oriented facing the central shared open space. The common courtyard and/or the pedestrian walkways have high importance, so parking spots are moved to the underground or periphery.

- Private spaces: residents own private residential units, every unit includes completed facilities (kitchen, dining room, living room, bedroom, and bathroom).

- Collective spaces: based on the intentional design, the common spaces such as the courtyard, garden, and common house are designed to supplement the private spaces. The

${ }^{36}$ Chiodelli, Baglione, "Living Together Privately: for a Cautious Reading of Cohousing", 22

${ }^{37}$ Ibid., 22-23

Scotthanson, Scotthanson, The Cohousing Handbook: Building a Palace for Community, 3-4

Fromm, Collaborative Communities: Cohousing, Central Living, and Other New Forms of Housing with Shared Facilities, 1-15 
common house typically includes a kitchen, dining area, laundry, and child care area. Based on the site extent, it may also consist of library, exercise area, offices, etc. developed on the site or remained undeveloped for future expansion.

- Nonhierarchical structure: in cohousing communities the decisions are made by all the members. Leadership responsibilities equally exist among cohousing residents.

- Residents' administration: the very essential characteristic of cohousing is the residents' participation and contribution in community's life. They collaborate in the daily activities such as attending regular meetings, making policies, preparing the common meals, cleaning of shared areas, etc., managing their community.

- No shared financial system: there is no shared income in a cohousing community. There might exist a commercial section on the site including variety of businesses that are organized privately.

\section{The Social Structure}

In terms of social context standpoint, a practical study states that contemporary cohousing can be classified into three main categories. ${ }^{38}$ The first is "building together" which refers to certain groups that produce housing in order to gain economical benefits rather than social relations. In the next category, "sharing everyday life", the members of groups collaborate together throughout the development process such as organizing the development and financing the project, and afterward in everyday activities for instance sharing meals. The last group is

\footnotetext{
${ }^{38}$ Korpela, "Casa Malta: A Case Study of a Contemporary Co-Housing Project in Helsinki", 336-337
} 
"serving a common ideal" in which certain groups build a community to serve particular ideology.

In a cohousing community, social interactions are enhanced through the social contact fostered through appropriate design so that residents have optimal opportunities for communication. The importance of design in influencing social interactions is explicated in details in literature. ${ }^{39}$ In general, the following design principles should be considered because of their significant impact on the "patterns of socializing": 40

- Close proximity to neighbors: residents living closely tend to communicate and socialize more with each other.

- Shared pathways: walkways connect various residential spaces and activity sites and provide opportunities for meeting, communication, and socialization.

- Shared open spaces: shared buffer zones such as gardens increase community interaction.

- Shared spaces: functional, accessible, and high quality collective spaces such as activity spaces and common facilities increase social interactions.

- Surveillance opportunities: by certain spatial layout, residents have the ability to observe the activities and people in the existing public spaces and surrounding environment, enabling them to decide their interactions and moreover strengthening the sense of security.

\footnotetext{
39 Fromm 1991; McCamant and Durrett. 1994; Fischer 1977; Cohen 1985; Birchall 1988; Meltzer 2005

40 Williams, "Designing Neighborhood for Social Interaction: The Case of Cohousing", 197-199

"Cohousing \& Sustainability" http://www.cohousing.ca/sustain.htm\#A
} 
- Low density residential community: residents tend to use shared spaces when smaller groups are using them for certain activities.

\subsection{Spatial Analysis}

As it was presented in the previous section, there are various spatial arrangements to design a cohousing community based on the desired level of privacy and community and the size of the community of residents. ${ }^{41}$ The spaces within which inhabitation occurs can be defined as private, semi-private, and public. Although certain design principles and layouts are required in order to create social encounters among inhabitants and promote the sense of belonging, the sense of being a part of a community is also dependent on the residents' own degree of participation. The studies show that the sense of community depends on the extent of common spaces as well as the social structure of the decision making process, the informal social relations, and the available resources for the residents of a specific community. ${ }^{42}$

\section{Private Spaces}

Private dwellings are designed in order to create sense of belonging to a community and a personal space. The spatial arrangement of dwelling units is designed in relation to the shared and public spaces in order to access collective spaces efficiently and easily and have visual connection to the community. The programmatic arrangement should provide a safe and

${ }^{41}$ Helamaa, "The Extended Home: On Design Solutions for Community Oriented Housing", 80

${ }^{42}$ Williams, "Designing Neighborhood for Social Interaction: The Case of Cohousing", 200 
secure living environment with opportunities for residents' surveillance. This is the space where inhabitants can express their personal lifestyle and be themselves.

\section{Semi-private Spaces}

The semi-private spaces are the most significant elements in the development and the success of a cohousing community as they provide the connection and transition between private and public areas. ${ }^{43}$ Creating semi-private spaces, the buffer zones, provides opportunities for social interactions through the design of pathways, garden spaces, and verandas and gathering spaces. ${ }^{44}$ The role of these spaces is then to be the "medium of integration". ${ }^{45}$ They provide a degree of privacy as they increase the potential for surveillance of the public space. In addition, as "the excellent interactional space", they enhance the interactions and meetings of residents and increase the potential for social relations even further. ${ }^{46}$

\section{Public Spaces}

With no doubt, public spaces are designed to support a variety of collective activities and to enhance the sense of belonging to a community. In general, public spaces are the physical place through which a communal culture emerges and collective activities take place as these spaces provide excellent opportunities for social interactions. Indoor or outdoor public courtyards, plazas, key activity sites, collective facilities, and the common house are required to

\footnotetext{
43 Horelli, "The Role of Shared Space for the Building and Maintenance of Community from the Gender Perspective - A Longitudinal Case Study In A Neighborhood Of Helsinki”, 60

44 Williams, "Designing Neighborhood for Social Interaction: The Case of Cohousing", 198

${ }^{45}$ Horelli, "The Role of Shared Space for the Building and Maintenance of Community from the Gender Perspective - A Longitudinal Case Study In A Neighborhood Of Helsinki”, 60

46 Williams, "Designing Neighborhood for Social Interaction: The Case of Cohousing”, 198
} 
be well-designed, visible, accessible, and suitable to accommodate all the community members for various events and activities. ${ }^{47}$ These spaces should be placed on shared pathways within residential dwellings in order to have visibility, which increases the sense of safety and accessibility maximizing potential for social relations. Some of the literature on the design of community through architecture recommends locating the public programs centrally and accessibly in order to maximize social interactions. ${ }^{48}$

\section{Arrangement and Connection}

The spatial arrangement of common public spaces can be designed for a clear visual access through the many common spaces used for different activities at the same time. The semiprivate spaces can be located as the buffer between the public space and the private dwelling units, or as a connection between public areas. How private and public spaces are connected has a great impact on the opportunities to use common spaces, and also on the quality of residents' social interactions. Indoor connections, both horizontal and vertical, provide spaces that can be used in any weather condition to enhance the sense of community. Outdoor connections create the visual boundary between private and public. ${ }^{49}$ Altogether, private, semi-private, and public spaces are arranged and connected based on their scale, their proximity, and the size of the sharing group.

\footnotetext{
${ }^{47}$ Williams, "Designing Neighborhood for Social Interaction: The Case of Cohousing", 199

${ }^{48}$ Fromm 1991; McCamant and Durrett 1994

49 Helamaa, "The Extended Home: On Design Solutions for Community Oriented Housing", 73-74
} 


\subsection{The Social Perspective}

Most researches on cohousing analyze and study the relationships between the design and social factors as well as their impact on residents' behavior as the core principle of this housing type. ${ }^{50}$ Cohousing can be defined as a process of social interaction among the inhabitants through their collaborative lifestyle. ${ }^{51}$ It utilizes socially intended design and formal social structures such as resident management to reinforce the informal social interaction in the community. ${ }^{52}$ The social framework improves residents' well-being.

This claim is supported by literature on social interaction which argues that the more supportive relationships exist among residents, the higher their well-being gets in terms of both physical and psychological health. In a study on social relationships and well-being, the author has identified social integration and social support as the main characteristics of the social environment that promote health. ${ }^{53}$ In this study, "social support" is referred to the facilities and resources available to benefit individual's ability to overcome negative life aspects such as financial and emotional support. The "social integration" is identified as the contribution and participation of inhabitants in the social activities. Thus, concluding that the existence of these factors in the social networks directly and positively impact the health outcomes of individuals. The analysis of another study presents that social networks and well-being of residents do not depend on the housing environment, whether living in urban or suburban neighborhoods. ${ }^{54}$ The findings actually show that the length of residence in a neighborhood increases residents' social

\footnotetext{
50 Fromm 1991; Krokfors 2012; McCamant and Durrett 1994; Meltzer 2000; Williams 2008

51 Krokfors, "Co-Housing in Making", 310

52 Williams, "Designing Neighborhood for Social Interaction: The Case of Cohousing”, 196

53 Cohen, "Social Relationships and Health", 676-678

54 Adams, "Is Happiness a Home in the Suburbs - the Influence of Urban versus Suburban Neighborhoods on Psychological Health", 353-354
} 
integration and quality of life, and consequently improves their well-being. This is particularly noticeable in cohousing communities in view of the fact that residents tend to live in a community for a very long period of time with an opportunity to develop lasting relationships. Hence, meaning that social integration is related to neighborhood satisfaction which is in fact connected with residents' well-being.

\subsection{The Urban Revitalization}

The study of many completed cohousing developments in various researches shows that this housing type can have positive impact on the wider context. ${ }^{55}$ In a broader sense, cohousing communities socially influence and invigorate their surrounding urban neighborhood. Not only it creates a close residential community within its own context, but also it positively impacts the neighboring environment. The integration with the neighborhood is evident in communities that are open to the surrounding neighbors for various collaborative activities such as locale meetings, variety of events, political support, and etc. Thus, it can be concluded that cohousing communities transform the derelict urban sites into vital residential communities as well as influence the surrounding neighborhood. ${ }^{56}$

The author of an article, MacCament, demonstrates examples of successful urban communities in North America, Doyle Street Cohousing in Emeryville, Berkeley Cohousing in Berkeley, USA, that have created stability and stronger social ties in their neighborhoods. ${ }^{57}$ Furthermore, the author of another research illustrates how the development of cohousing

\footnotetext{
55 Fromm 2012; McCamant and Durrett. 1994; Krokfors 2012; McCamant 1999

56 McCamant, Kathryn. "Cohousing Communities: A Model for Reinvigorating Urban Neighborhoods"

57 Ibid.
} 
communities with open public spaces to local neighborhood has increased the quality and the security of the surrounding environment, creating a larger community. ${ }^{58}$ The instances presented are Swan's Market in Oakland, USA, and Goethestrasse in Bremerhaven, Germany.

\subsection{The Sustainable Approach}

Considering various aspects of cohousing, it certainly has positive impact on the neighborhood level as well as society at the broader level; revealing “...the means by which people might live in civilized and enduring propinquity within a mainstream context". 59 It addresses the lack of social contacts and sustainable living as some of the most important problems facing today's contemporary society. In general, many researches affirm that the intentional design along with the existence of strong social factors and shared resources create a socially, environmentally, and economically sustainable housing type. ${ }^{60}$ The sustainable side of cohousing is essentially besides its environmentally responsive design features, since it has been developed and evolved over the years as a response to the matter of loss of community in present societies, therefore resulting in "... ecological interconnectivity of the social and environmental dimensions of sustainability". ${ }^{61}$

The social gain comes from the high levels of collaboration and social support networks through the following means: diversity of residents that form connections together, opportunities for public participation, safety and security in knowing the neighbors, equal opportunity for

\footnotetext{
58 Fromm, "Seeding Community: Collaborative Housing as a Strategy for Social and Neighborhood Repair", 365 391

59 Meltzer, "Cohousing: Verifying the Importance of Community in the Application of Environmentalism”, 124

60 Williams 2008; Meltzer 2005; Meltzer 2000; Krokfors 2012; Meltzer, Graham. "How Does Cohousing Create Sustainability?"

${ }^{61}$ Meltzer, Sustainable Community: Learning from the Cohousing Model, 15
} 
inhabitants to do different activities, reduced need for external infrastructure, etc. The positive environmental consequences are the result of "social cohesion and trust that facilitate sharing and collaboration which makes possible a range of practical savings..." ${ }^{62}$ for instance organic gardening, efficient land use, efficient water and waste management, effective transportation alternatives such as car pooling, preserving energy resources, exchanging and sharing resources, etc. Furthermore, as the final point, the economical value of this model is achieved through the residents' management of the development resulting in an environmentally sensitive community, cost efficient development, accessibility to shared resources which reduces residents expenditure, and growing market demand for cohousing life that adds significant sale value on account of its quality of life benefits. ${ }^{63}$

As it is mentioned earlier, self-efficacy, cooperation, and supportive social relationships positively impact individuals' well-being. Thus, as Meltzer states, this well-being is no more associated with the materialist notion of contemporary societies; rather it is in direct relation to the considerate and altruistic nature of cohousing communities. ${ }^{64}$ The intentional design and social factors, per se, help creating the immensely desired sense of belonging.

\footnotetext{
${ }^{62}$ Meltzer, Sustainable Community: Learning from the Cohousing Model, 15

63 "Cohousing \& Sustainability" http://www.cohousing.ca/sustain.htm\#A

64 Meltzer, Graham. "How Does Cohousing Create Sustainability?"
} 


\section{Precedent Studies}

\subsection{Comparison of Housing Typologies in Canada}

\section{The Ownership Structure}

The residential typologies in Canada and North America can be generically categorized to three existing legal forms of cooperative, condominium, and cohousing in terms of the ownership structure and design. ${ }^{65}$ The co-operative model refers to non-for-profit housing provided for mixed income residents where typically members do not own equity and most members have low income. Co-operatives have both "market units", where the member pays full market price for the property and "subsidized units" where each household pays a reduced monthly rent based on their income and the government subsidizes part of the payment with the full co-operative's charge. ${ }^{66}$ Conversely, in equity co-operative, for-profit, each household owns their unit through purchasing certain share of the unit's total value which is under the market price. ${ }^{67}$ The share value does not fluctuate with the market changes. ${ }^{68}$ In general, the cooperative Board of Directors that is composed of members of the community decides whether a buyer can purchase a unit. This type of ownership is not common in Canada, since its financing is very difficult due to the fact that the shareholder does not hold the title to the unit.

\footnotetext{
65 Scotthanson, Scotthanson, The Cohousing Handbook: Building a Palace for Community, 7-8

66 "Co-op Housing: An Affordable Alternative, A Good Place to Call Home" http://www.coophousing.com/about/about_housing.asp

67 "Guide to Co-operative Housing" https://www.cmhc-schl.gc.ca/en/co/buho/gucoho/

68 “What Is a Housing Co-op?” http://www.chfcanada.coop/eng/pages2007/about_1.asp
} 
The condominium type allows individual ownership of a private home, in a low-rise, high-rise apartment buildings or row houses, along with the right of use and access of common facilities. In U.S. and Canada, the condominium legal structure is called "strata title"69 in the form that each household owns a private home and shared ownership of common amenities. ${ }^{70}$ The ownership process is considered uncomplicated to be financed, since potential buyers can use banks' mortgages based on their financial status. The resale value of purchased units fluctuates with the market. This type is very common in Canada.

The cohousing model can be owned and operated as a condominium or as a cooperative. However, condominium ownership would be more beneficial because it can be financed without any difficulty. Thus, it can be considered a hybrid type, since it gets financed without any difficulty through banking unlike cooperative and is managed collaboratively by the residents themselves unlike a typical condominium homeowner's association. ${ }^{71}$ The statistics show that most cohousing communities in U.S. and Canada prefer the condominium legal structure, strata title, by which every owner owns a private unit and shared ownership of common facilities. ${ }^{72}$ A unit in a cohousing community, under the Condominium Act, is sold for the market value unless there are certain covenants in place that restrict the resale value. It is also the responsibility of the seller to prepare the community about the new owner and the potential owner about the community structure.

\footnotetext{
69 "Strata Title" is a form of ownership set up for multi-level apartments with shared areas. It allows for individual ownership of an apartment, called a 'lot', as a part of the property with shared ownership of the remainder space. This is an Australian system that has been adopted by Canada.

${ }^{70}$ Scotthanson, Scotthanson, The Cohousing Handbook: Building a Palace for Community, 8-12

${ }^{71}$ Ibid., 4

${ }^{72}$ Ibid., $8-12$
} 


\section{The Design Layout}

In a co-operative housing, the design of the building is generally intended to satisfy affordable housing requirements and the design of the units is typical of a residential apartment. Co-operatives also do not necessarily include common spaces or shared facilities. ${ }^{73}$ But when there are, the design incorporates indoor or outdoor social spaces such as event rooms, meeting rooms, and garden spaces. For instance the design of 60 Richmond Street East housing cooperative in Toronto, has shared indoor and outdoor amenity spaces and gardens within the vertical 11-storey building. This type offers housing for low to moderate income individuals. Also, many of the co-operative housing in Canada are developed for a specific group of residents for example Arcadia Court in Toronto for people working in the arts and 60 Richmond Street East for low income downtown hotel employees.

The design consideration of a condominium building is more concentrated on the private residential units than the public facilities on-site. In general, in order to attract prospective owners, many public spaces are designed, such as cyber room, theater room, guest room, party room, exercise room, pool, etc. Common spaces are typically located within particular zones like the ground level that do not interconnect with the main residents' flow through the building. The vertical circulation in high-rise condominium buildings is mainly by elevators, so there is no chance of shared connecting pathways. For the horizontal circulation on each level, the corridors are designed in order to efficiently access the residential units, not to create opportunities to meet and to interact. Thus, shared spaces have less importance in size and location compared to the residential units considering that the average number of units in

\footnotetext{
73 Krokfors, "Co-Housing in Making”, 309
} 
condominium projects has been around $218^{*}$ in recent years. ${ }^{74}$ This is a luxury development for mainly high income and wealthy individuals such as ARC condos in Toronto.

Cohousing somehow functions similar to condominium development considering that it uses the same ownership structure and the design utilizes common amenities. However, cohousing is specifically designed to promote social interactions for the sense of belonging to a community. The spatial layout of the private space is in relation to shared and public spaces. Cohousing communities have considerably more common facilities than most co-operatives and condominiums. ${ }^{75}$ The common amenities are placed within the private dwellings and are easily accessed by the residents. The main circulation paths to the residential units are usually through or in close proximity to the shared spaces promoting high interactions. The model is home to diverse multi-generational groups of residents with a range of incomes. Diversity is the core value. A few communities are also designed particularly for certain groups of people such as Harbourside senior cohousing in Victoria, BC.

\section{The Social Relation}

With no doubt, it should be considered that design in any residential type certainly has an effect on the quantity and quality of social relations between residents. In co-operative housing, members approve new members and have opportunities to create a safe community. ${ }^{76}$ Living in a co-operative building requires social involvement of members as they work together

\footnotetext{
74 “GT Condo" http://www.realnet.ca/gta-condo-building-size-total-units/

* This number is based on an analysis of the average number of units per condominium project in GTA from 2005 to 2012 .

75 Scotthanson, Scotthanson, The Cohousing Handbook: Building a Palace for Community, 3

76 "What Is a Housing Co-op?" http://www.chfcanada.coop/eng/pages2007/about_1.asp
} 
to make decisions, maintain the building, participate in various activities, interact with others, and sustain the integrity of the community. This offers, however, some degree of community but not to the same extent as cohousing does.

In the condominium model, the social interaction aspect is not contemplated through design. Although there exists a certain number of public amenities for the residents, they are mainly used by individual residential units and not by the residents together. For example a theater room or a party room can be booked by one unit at a time. Thus, the public spaces are not so 'public' as the residents tend to use them privately. This residential model offers a luxury lifestyle, indeed, for high-income buyers who normally are not interested in the social aspect of their living environment rather are looking for comfort and services within the place of residency, all to satisfy the consumer culture.

In the cohousing model, the social relations are achieved through certain design aspects such as shared spaces, green spaces, the common house, lounges, connecting pathways, etc. The design maximizes the much intended social interactions. Moreover, unlike a typical condominium, residents have certain values of acceptance, trust, privacy, collaboration and participation. They share meals regularly, organize group events, meet frequently, and participate in the management and maintenance of the community. Therefore, a shared vision of living in a community by the means of designed spaces for interactions are what distinguishes the cohousing model from any other types. ${ }^{77}$ Table 1 presents a detailed comparison between these models. $^{78}$

\footnotetext{
77 “What Is Cohousing?” http://www.cohousing.ca/whatis.htm

78 “Condominium Buyers' Guide” http://www.cmhc-schl.gc.ca/en/co/buho/cobugu/cobugu_002.cfm
} 


\begin{tabular}{|c|c|c|c|}
\hline & Co-operative & Condominium & Cohousing \\
\hline $\begin{array}{l}\text { Ownership } \\
\text { structure }\end{array}$ & $\begin{array}{l}\text { no ownership in non-profit, } \\
\text { long-term fixed-value shares } \\
\text { in equity model }\end{array}$ & $\begin{array}{l}\text { every owner has private } \\
\text { ownership of each unit and } \\
\text { common ownership of the } \\
\text { shared facilities }\end{array}$ & $\begin{array}{l}\text { private ownership of the unit } \\
\text { and shared ownership of } \\
\text { common amenities by strata } \\
\text { title }\end{array}$ \\
\hline Purpose & affordable housing & $\begin{array}{l}\text { residential housing, mostly } \\
\text { with luxurious design }\end{array}$ & $\begin{array}{l}\text { creating neighborhood that } \\
\text { satisfies residents' needs for } \\
\text { a balanced life style in private } \\
\text { homes and community } \\
\text { environment }\end{array}$ \\
\hline Owners & $\begin{array}{l}\text { usually diverse members of } \\
\text { low and moderate income } \\
\text { individuals, or specific group } \\
\text { of people }\end{array}$ & $\begin{array}{l}\text { diverse owners, average to } \\
\text { high income individuals }\end{array}$ & $\begin{array}{l}\text { diverse multi-generational } \\
\text { residents with a range of } \\
\text { household incomes, or } \\
\text { specific group of people }\end{array}$ \\
\hline $\begin{array}{l}\text { New } \\
\text { members }\end{array}$ & $\begin{array}{l}\text { new owners are approved by } \\
\text { the co-operative Board of } \\
\text { Directors elected by members }\end{array}$ & $\begin{array}{l}\text { initially, units are sold by the } \\
\text { developer, after that owners } \\
\text { and buyers act independently }\end{array}$ & $\begin{array}{l}\text { the initial recruitment is done } \\
\text { by the community or by the } \\
\text { developer under the } \\
\text { acceptance of the community } \\
\text { members, in the case that a } \\
\text { unit is sold by an owner, the } \\
\text { seller should inform the } \\
\text { community and educate the } \\
\text { buyer }\end{array}$ \\
\hline $\begin{array}{l}\text { Policies and } \\
\text { regulations }\end{array}$ & $\begin{array}{l}\text { the policies are determined by } \\
\text { the co-operative members }\end{array}$ & $\begin{array}{l}\text { decisions are mainly made by } \\
\text { Board of Directors elected by } \\
\text { owners or in specific cases by } \\
\text { members' votes, policies } \\
\text { should be made under the } \\
\text { "Condominium Act" }\end{array}$ & $\begin{array}{l}\text { non-hierarchical decision } \\
\text { making by all the community } \\
\text { members, a consensus } \\
\text { decision process }\end{array}$ \\
\hline Development & $\begin{array}{l}\text { government funds the } \\
\text { development and there is no } \\
\text { profit gain }\end{array}$ & $\begin{array}{l}\text { corporations or individual } \\
\text { developers finance the project } \\
\text { and make profit from it }\end{array}$ & $\begin{array}{l}\text { the future residents finance } \\
\text { and participate in design and } \\
\text { development process, but } \\
\text { recently it is mostly done by } \\
\text { developers due the risks and } \\
\text { difficulties involved in the } \\
\text { conventional approach }\end{array}$ \\
\hline
\end{tabular}

"Guide to Co-op Housing" https://www.cmhc-schl.gc.ca/en/co/buho/gucoho/ 


\begin{tabular}{|l|l|l|l|}
\hline $\begin{array}{l}\text { Financing a } \\
\text { unit }\end{array}$ & $\begin{array}{l}\text { in equity model, difficult to } \\
\text { get a mortgage on a unit } \\
\text { because the shareholder does } \\
\text { not hold the title to it }\end{array}$ & $\begin{array}{l}\text { easy to get a mortgage on a } \\
\text { unit }\end{array}$ & $\begin{array}{l}\text { easy to get a mortgage on a } \\
\text { unit }\end{array}$ \\
\hline Resale value & $\begin{array}{l}\text { by covenants in equity model, } \\
\text { the value is fixed and does nor } \\
\text { fluctuate with the market over } \\
\text { the time }\end{array}$ & $\begin{array}{l}\text { the value is at the market } \\
\text { price }\end{array}$ & $\begin{array}{l}\text { the value is at the market } \\
\text { price }\end{array}$ \\
\hline $\begin{array}{l}\text { Design } \\
\text { components } \\
\text { shared facilities are not } \\
\text { common }\end{array}$ & $\begin{array}{l}\text { private residential units and } \\
\text { common facilities on-site }\end{array}$ & $\begin{array}{l}\text { private residential units and } \\
\text { extensive shared facilities on- } \\
\text { site by social design for } \\
\text { optimal residents' interaction }\end{array}$ \\
\hline Social aspect & $\begin{array}{l}\text { members cooperatively live in } \\
\text { a community }\end{array}$ & $\begin{array}{l}\text { very limited due to the nature } \\
\text { of the model, no sense of } \\
\text { community }\end{array}$ & $\begin{array}{l}\text { highly community-oriented } \\
\text { design for optimal social } \\
\text { interactions among residents }\end{array}$ \\
\hline
\end{tabular}

Table 1: A comparison of cohousing vs. condominium vs. co-operative residential type

\subsection{Residential Developments in Toronto}

In Toronto, there are 164 non-for-profit co-operative housing and many equity cooperatives buildings. ${ }^{79}$ Also, the rise of condominium buildings in Toronto has made the city to become the largest market in North America in recent decades. ${ }^{80}$ In fact, the development of condominiums has surpassed the development of other types of ownership or rental residential buildings.

\footnotetext{
${ }^{79}$ Novac, Lapointe, Analysis of Evictions in the City of Toronto: Co-operative Housing Sector, 1

${ }^{80}$ Wong, Tony. "Condo Sales Booming"
} 
With regards to cohousing as the "new response to social, economical, and environmental challenges of the $21^{\text {st }}$ century ${ }^{\prime \prime}{ }^{81}$ there are nearly 300 completed projects in Denmark and more than 125 communities in United States. ${ }^{82}$ Canada, in contrast, only hosts 11 completed communities (Table 2) ${ }^{83}$ Cohousing is relatively new to Canada and its development was initiated around 1996 in British Columbia. The Canadian Cohousing Network (CCN), established in 1992, is the Canadian cohousing association that promotes the development of cohousing communities as a sustainable model for residential development. $\mathrm{CCN}$ has classified the cohousing communities in Canada according to their location and status of "forming, developing, and completed". Based on this report, the majority of cohousing communities are located in British Columbia. Ontario has the second rank in the list including mostly forming projects and only one completed community: Terra Firma Co-housing in Ottawa. The share of Toronto megacity in this list is only one development in the planning process named Toronto ecoHousing Community. ${ }^{84}$

\footnotetext{
81 "What Is Cohousing?" http://www.cohousing.ca/whatis.htm

82 Scotthanson, Scotthanson, The Cohousing Handbook: Building a Palace for Community, 2

Thompson, Claire. "Cohousing: the Secret to Sustainable Urban Living?"

83 "Community Summary" http://www.cohousing.ca/summary.htm

84 Ibid.
} 


\begin{tabular}{r|c|c|c|c|c|}
\hline & forming & developing & completed & total \\
\hline British Colombia & 5 & 6 & 7 & 18 \\
\hline Ontario & 4 & & 1 & 5 \\
\hline Alberta & & 1 & 1 & 2 \\
\hline Quskatchewan & & 1 & 1 & 2 \\
\hline total & & & & 1 & 1 \\
\hline
\end{tabular}

Table 2: Cohousing communities in Canada. From Canadian Cohousing Network http://www.cohousing.ca/summary.htm

\subsection{Examples of Successful Community-oriented Housing Projects}

In order to better understand the features and structure of community-oriented housing, it is very important to study the various cohousing developments particularly in Canada and North America. This section presents the research and analysis done on successful cohousing projects varying in site, scale, aspects, and characteristics. 


\section{1- Swan's Market, Oakland, California, United States}

\section{The Design}

One of the most successful models in cohousing community in North America is Swan's market a mixed-use historic-preservation project located in downtown Oakland, CA. ${ }^{85}$ The cohousing residential project was a part of a larger redevelopment that included the adaptive reuse of a historic building on the site known as Swan's Marketplace. ${ }^{86}$ This diversely occupied cohousing community along with the preserved abandoned building resulted in a thriving renewal of downtown district of the city of Oakland. It is also one of the densest urban cohousing communities that has become deeply and completely integrated within its neighborhood. Taking up one city block, it is located within a ten-minute walk from public transit and a twelve-minute ride to downtown San Francisco, well connected with existing local facilities. ${ }^{87}$ In fact, it combines the benefits of living the city life of downtown locale and cohousing social ties.

The design attributes of cohousing in the complex includes the cohousing units, affordable housing, and commercial and business sectors. The residential private zone includes twenty units with fifteen variations of an average dwelling size of 95 sqm, mostly two-storey townhouses that are organized along side of a shared pedestrian street. The common house is centrally located. The public zone is placed around the "village square" where entertainment, gatherings, and informal interactions happen. The affordable housing building includes

\footnotetext{
85 McCamant, Durrett, Creating Cohousing: Building Sustainable Communities, 180

${ }^{86}$ Meltzer, Sustainable Community: Learning from the Cohousing Model, 77

87 McCamant, Durrett, Creating Cohousing: Building Sustainable Communities, 183
} 
apartments in the upper two levels and shops at the ground level. The revived market is located along with shops and restaurants. It can be categorized as follow: ${ }^{88}$

- 20 dwelling units of studio, one and two-bedroom

- a common house including kitchen, dining room, living room, children space, laundry room, exercise room, guest room, workshop space, and parking space

- 18 rental units of one and two-bedroom for low-income households

- retail space including a café, restaurants, and shops

- commercial space including an architectural firm, a TV channel, and community organizations

- many art and craft galleries, and the Museum of Children's Art

- a historic fresh food market

Swan's Market Cohousing

Oakland, California, USA

Status: Completed

Established: 2000

Site: Urban

Site area: $1,011.71 \mathrm{~m}^{2}$

Common area: $465 \mathrm{~m}^{2}$

Architect: Michael Pyatok \& Associates

Development: Adaptive reuse

Tenure: Condominium

Design: 20 units, common facilities

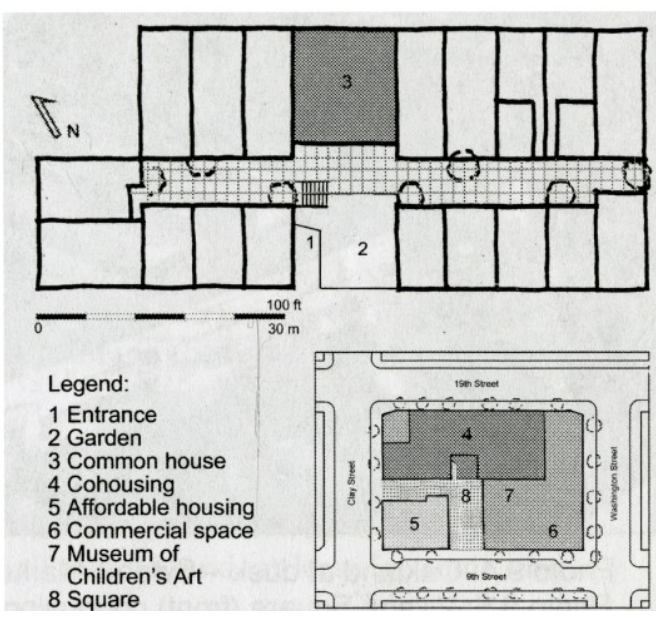

Figure 8: Site plans. From Meltzer, Sustainable Community: Learning from the Cohousing Model, 77

${ }^{88}$ Meltzer, Sustainable Community: Learning from the Cohousing Model, 77-80 

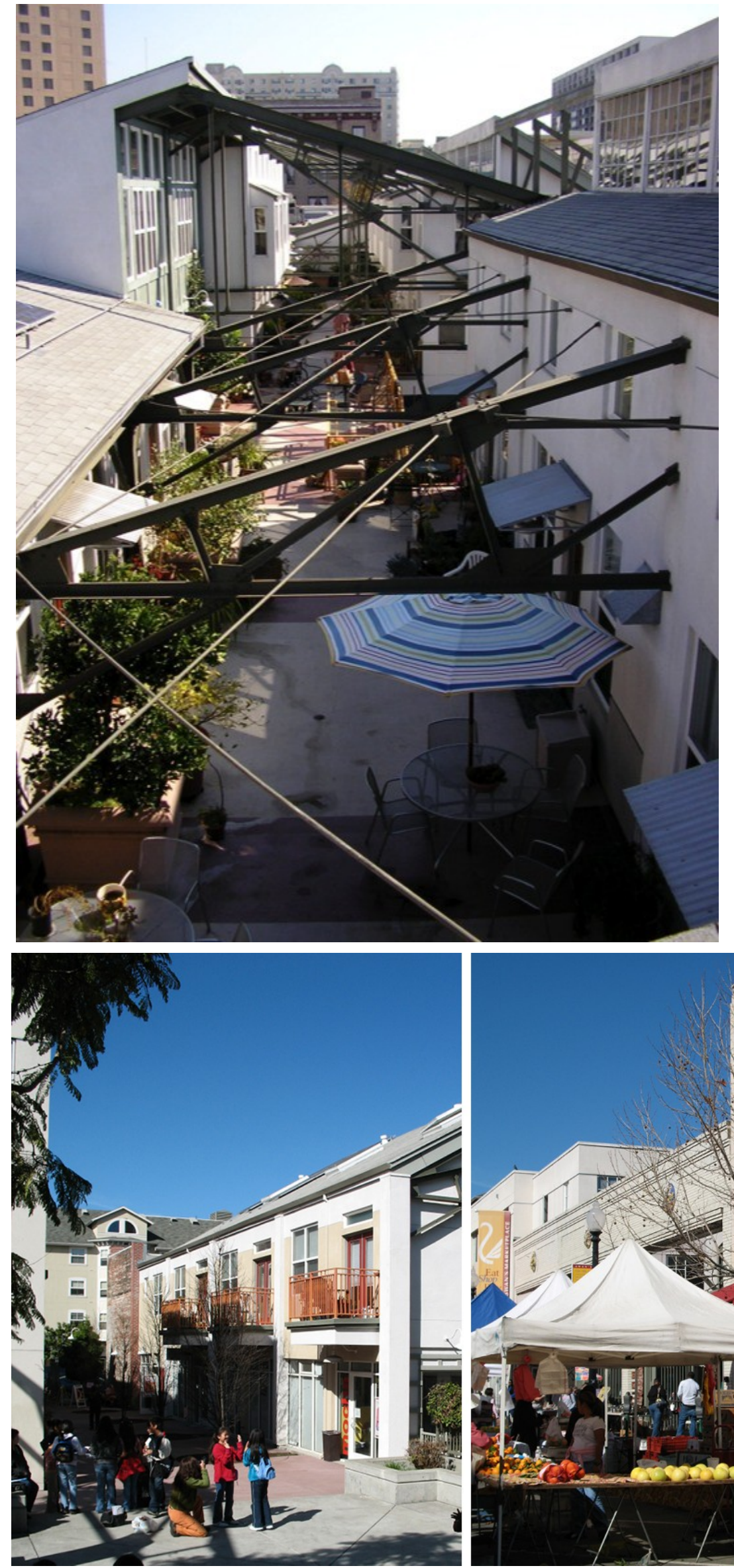

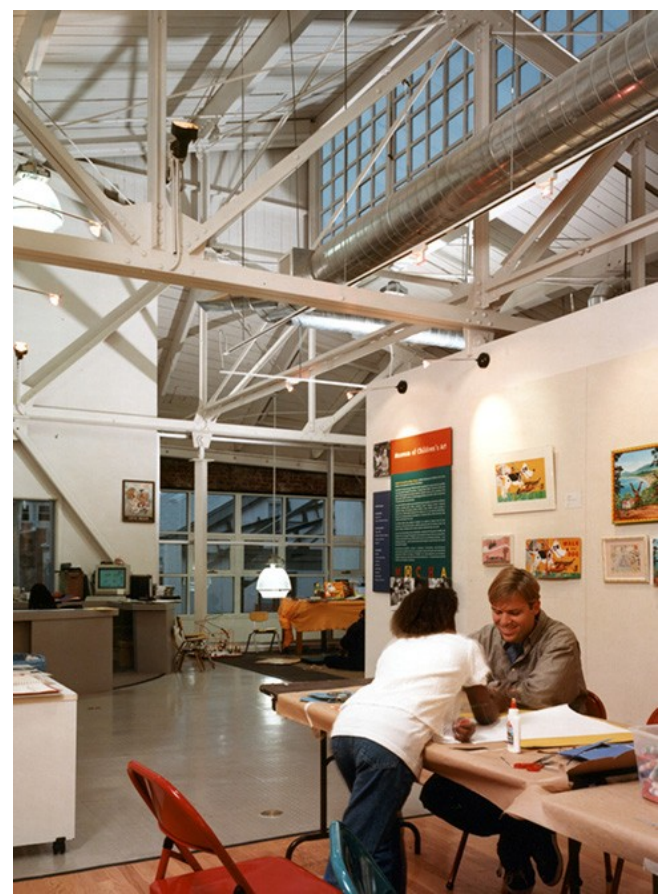

Figure 9: Cohousing pedestrian street (left). Image courtesy of Swan's Market Cohousing http://www.swansway.com/

Figure 10: The common area (right). Image courtesy of Pyatok \& Assoc. http://www.pyatok.com/work/project/11 2/SWANS-MARKET

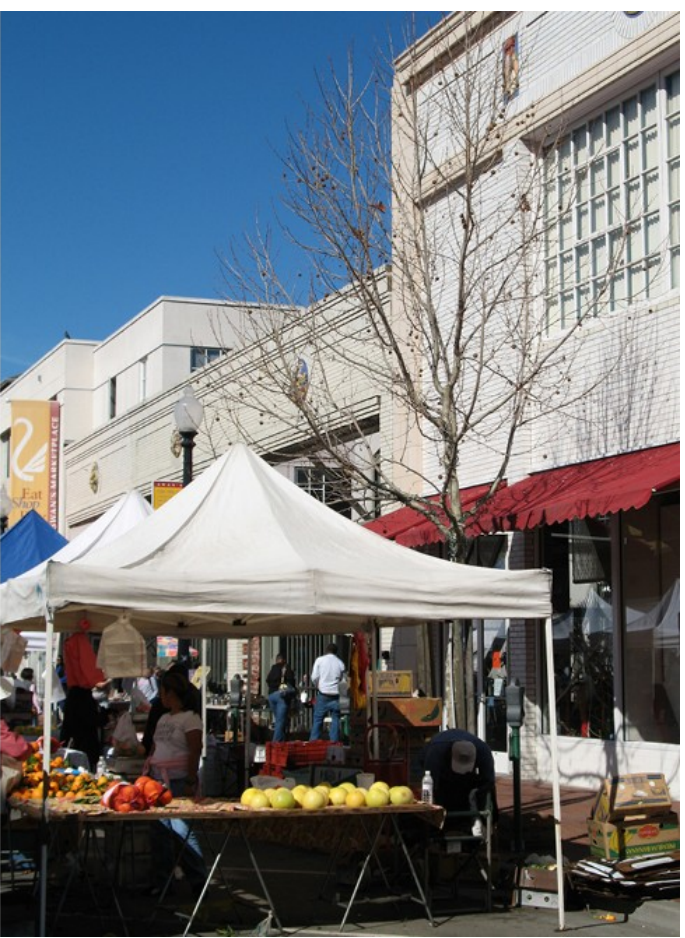

Figure 11: The village square (left), and the historic market (right). Image courtesy of Pyatok \& Assoc. http://www.pyatok.com/wo rk/project/112/SWANSMARKET 


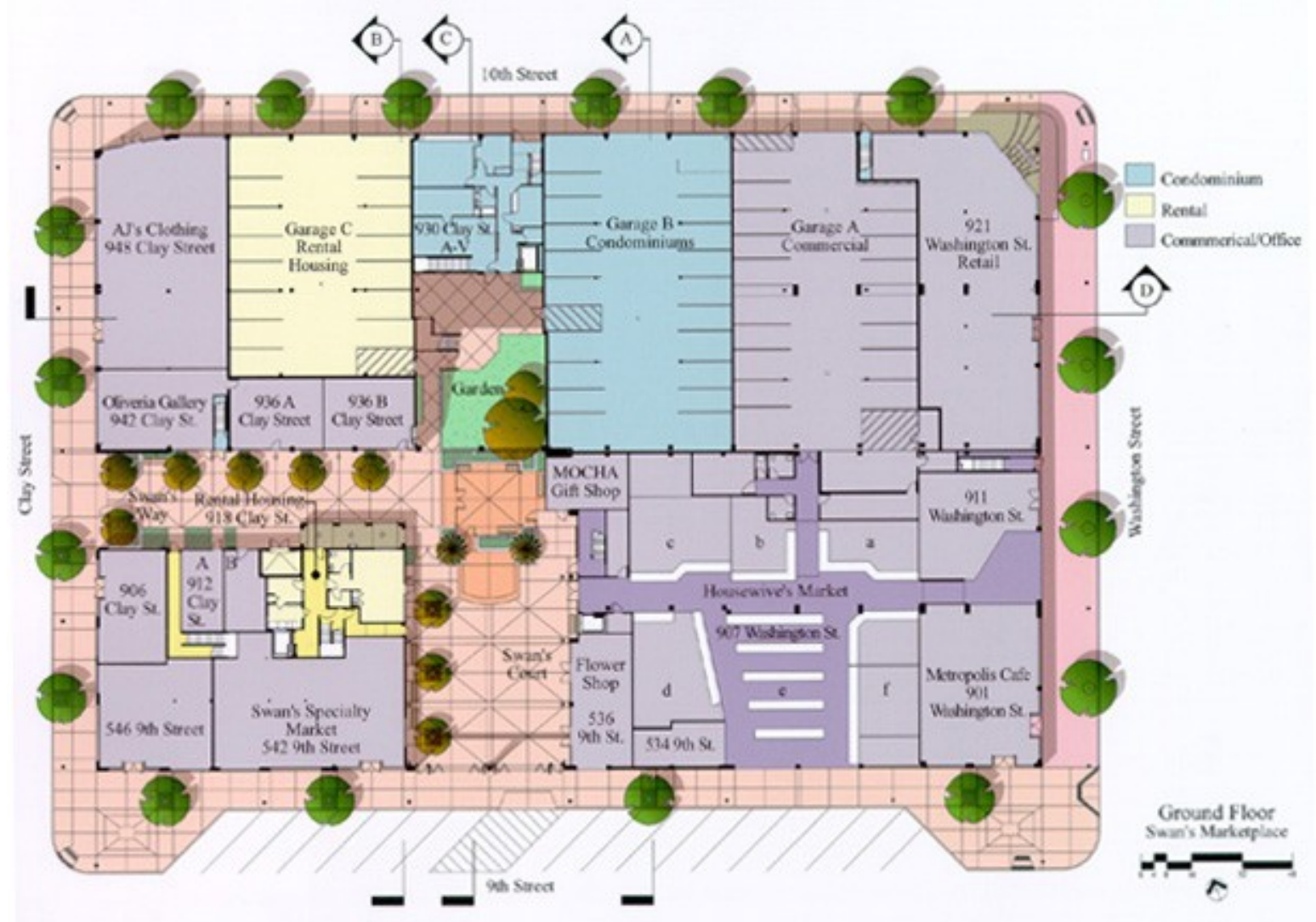

Figure 12: Ground floor plan. Image courtesy of Pyatok \& Assoc. http://www.pyatok.com/work/project/112/SWANS-MARKET

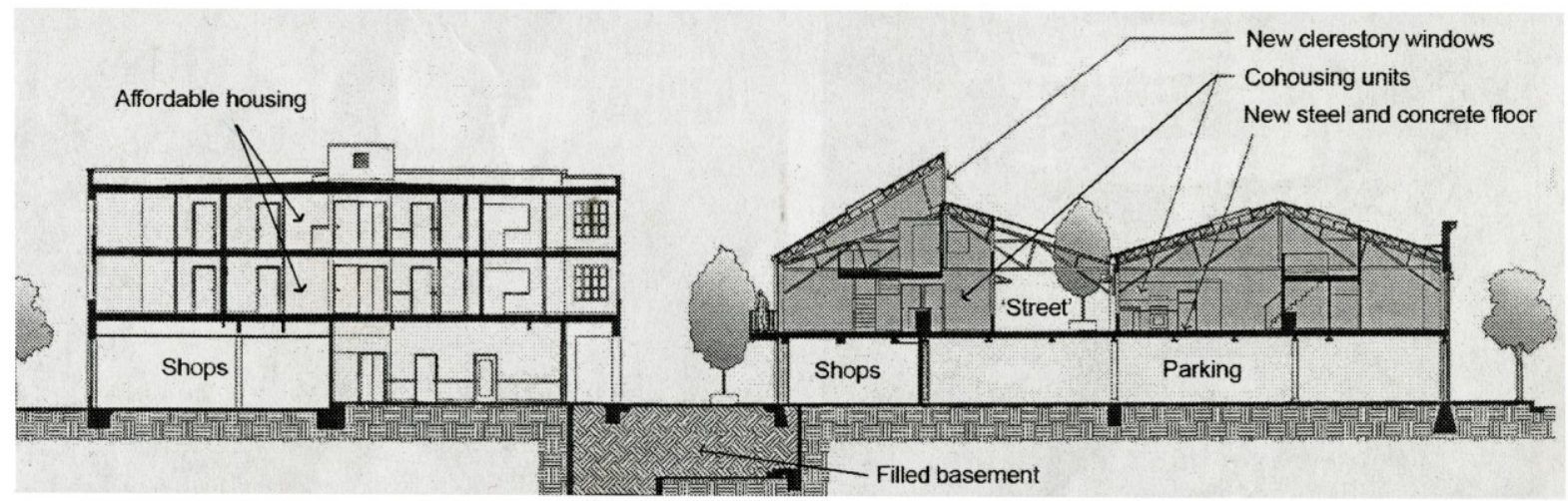

Figure 13: Site section (Drawing by Pyatok \& Assoc.). From Meltzer, Sustainable Community: Learning from the Cohousing Model, 79 


\section{Results and Impacts of the Community}

The diversity of cohousing design features and the revitalized historic market site has transformed the downtown neighborhood into a vibrant cohousing community, attracting high numbers of tourists and locals to the site. Furthermore, the project encompasses social and economical sustainability considering that an urban infill community brings the vivacious social life to the surrounding neighborhood, the retail space enhances the liveliness of the neighborhood as well as increases the employment opportunities, and moreover reuse of existing building and building energy efficient dwellings save resources. ${ }^{89}$

\section{2- Doyle Street, California, United States}

\section{The Design}

Doyle Street is a compact urban infill cohousing community located in the small town of Emeryville. The project was developed by building a new storey over a renovated one-storey warehouse to meet the needs of its future residents: searching for a sense of community. ${ }^{90} \mathrm{~A}$ neighborhood park and community gardens are in a close distance to the community providing social opportunities with the larger neighborhood. The cohesiveness of the community is based on the residents' commitment and accountability to one another and the community's common

\footnotetext{
89 McCamant, Durrett, Creating Cohousing: Building Sustainable Communities, 183 Meltzer, Sustainable Community: Learning from the Cohousing Model, 83

90 McCamant, Durrett, Creating Cohousing: Building Sustainable Communities, 143
} 
goals. ${ }^{91}$ This is a successful project of transforming an old warehouse into a modern cohousing living.

The complex consists of two adjoining buildings in which 6 units and a common house are retrofitted, and the additional second level allowed for 12 loft-style condominium units. The units are sized from $72.46 \mathrm{sqm}$ to $148.64 \mathrm{sqm} .{ }^{92}$ The buildings are placed around a parking lot and a courtyard that accommodates a garden, a sitting area during warm weather, and a play area. The entrance to each unit opens on a common patio landscaped by the residents in order to have green spaces within the site. ${ }^{93}$

- 12 units of two-bedroom, some with a small loft above the master bedroom and an extra storage closet above the second bedroom

- Common area including a kitchen, a sitting area, a dining room, a children's playroom, a workshop, a recreational room, a hot tub, a laundry room, and storage space

${ }_{91}$ McCamant, Durrett, Creating Cohousing: Building Sustainable Communities, 149

${ }^{92}$ Ibid., 144

${ }^{93}$ McCamant, Durrett, Cohousing: A Contemporary Approach to Housing Ourselves, 218-219 
Doyle Street Cohousing

Emeryville, California, USA

Status: Completed

Established: 1992

Site: Urban

Site area: $1,214.06 \mathrm{~m}^{2}$

Common area: $195.09 \mathrm{~m}^{2}$

Architect: McCamant \& Durrett Architects

Development: Adaptive reuse

Tenure: Condominium

Design: 12 condominium units in 2 adjoining buildings, 1 common house

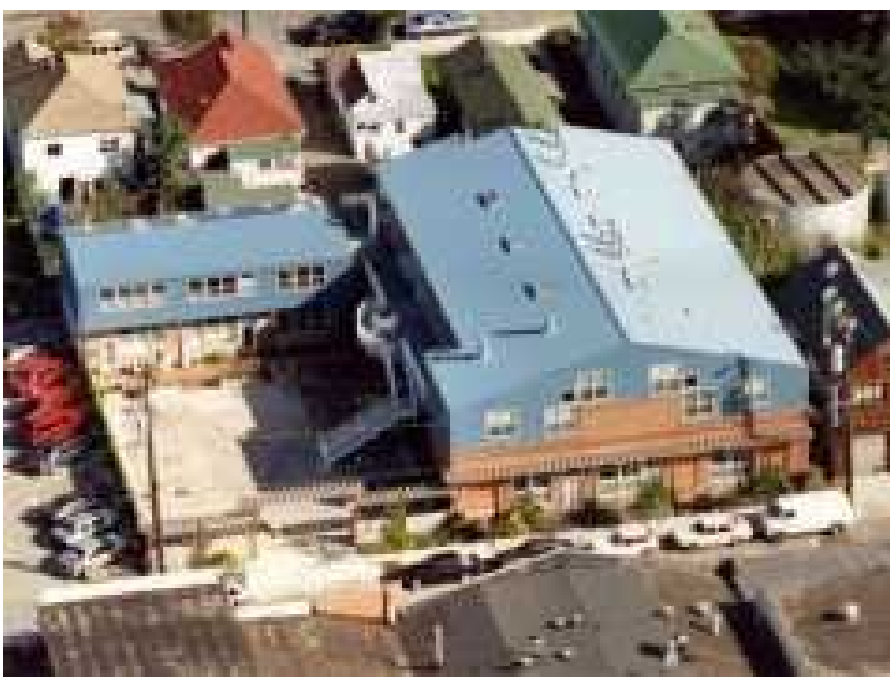

Figure 14: Doyle Street cohousing in 1992 when completed. Image courtesy of Doyle Street Cohousing http://www.emeryville-cohousing.org/gallery--links.html

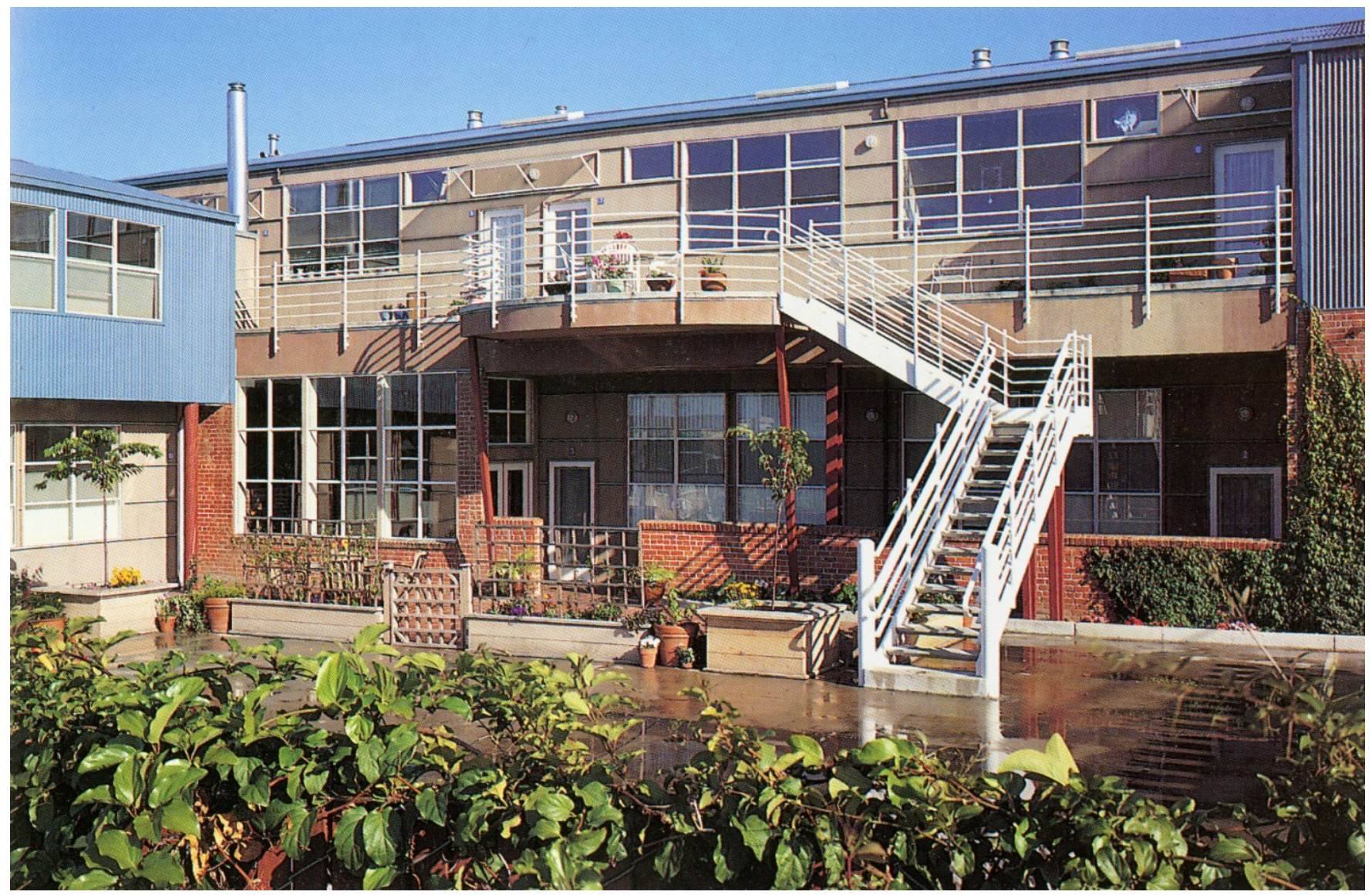

Figure 15: Community view from the courtyard. From McCamant and Durrett, Cohousing: A Contemporary Approach to Housing Ourselves, 227 

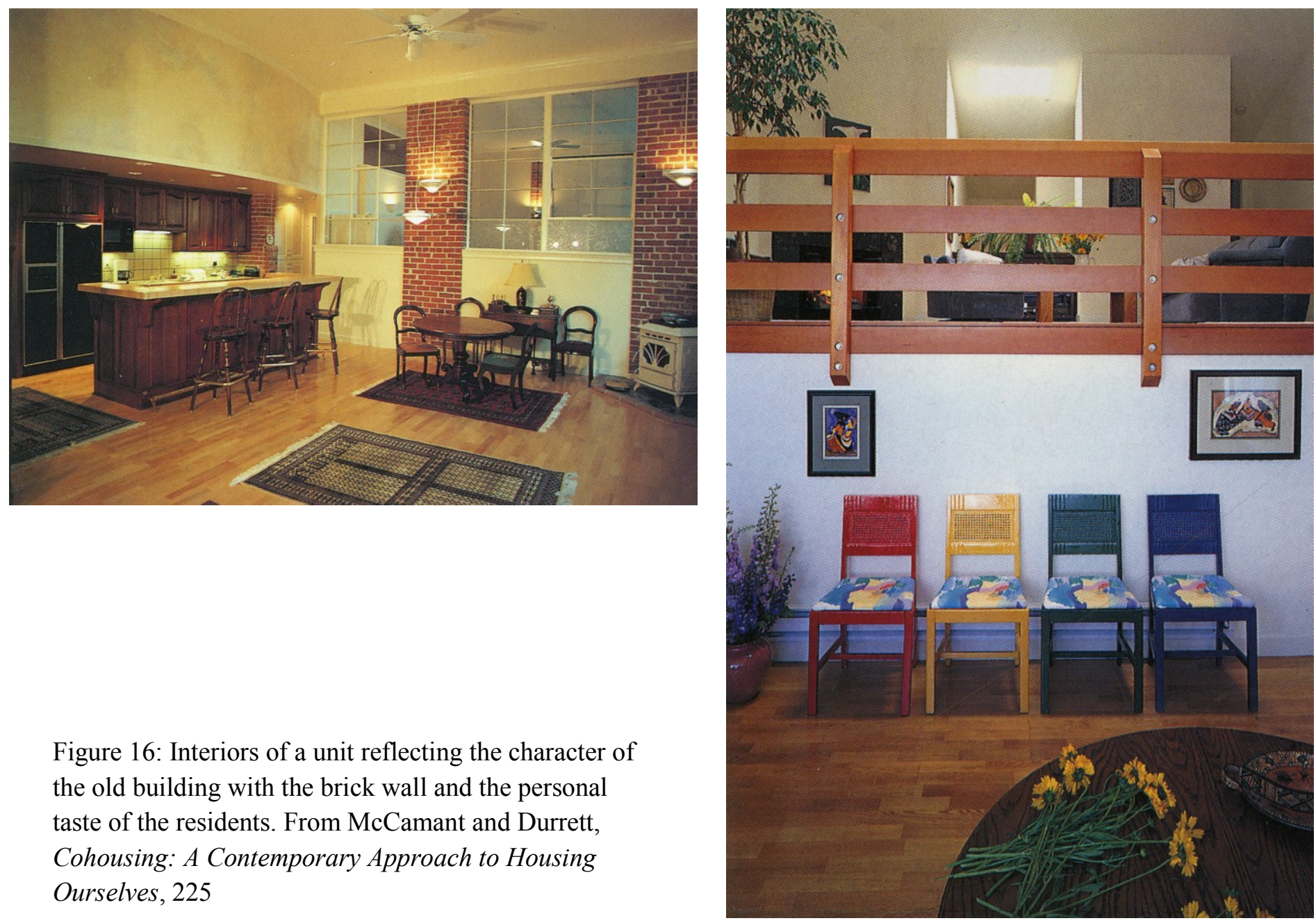

Figure 16: Interiors of a unit reflecting the character of the old building with the brick wall and the personal taste of the residents. From McCamant and Durrett, Cohousing: A Contemporary Approach to Housing Ourselves, 225

Figure 17: Neighbors gathering in Spring 2011. Image courtesy of Doyle Street Cohousing http://www.emeryville-cohousing.org/gallery---links.html

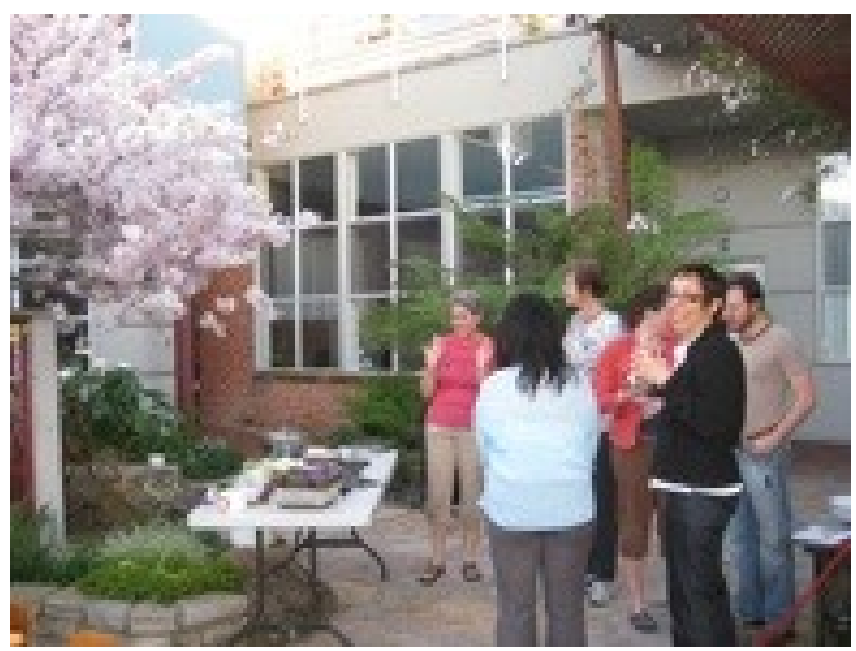


Figure 18: The ground floor plan. From McCamant and Durrett, Cohousing: A Contemporary Approach to Housing Ourselves, 220

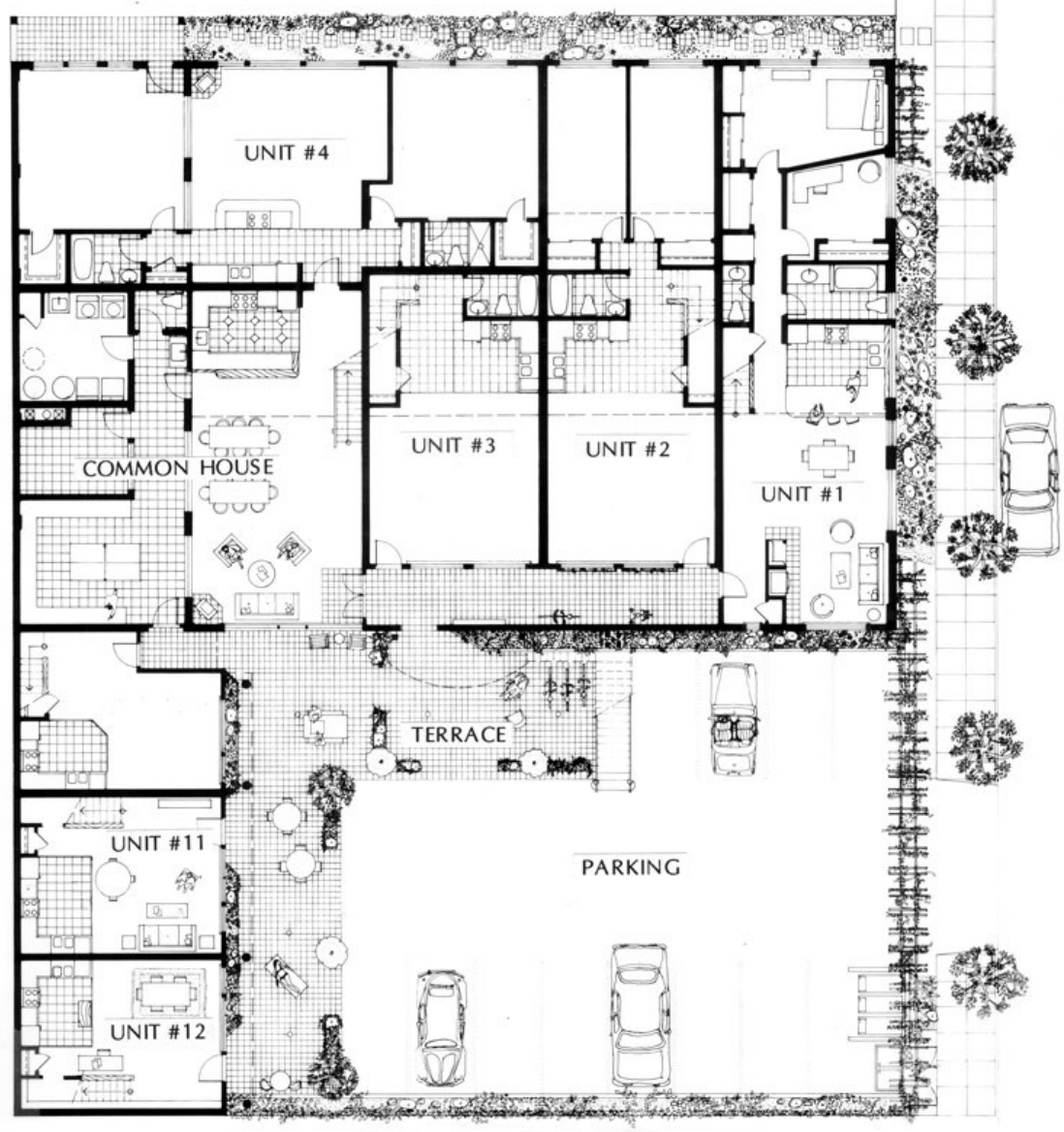

Figure 19: Section of the building showing the lower and upper units, lofts and mezzanine make use of the double height ceiling. From McCamant and Durrett, Cohousing: A Contemporary Approach to Housing Ourselves, 223

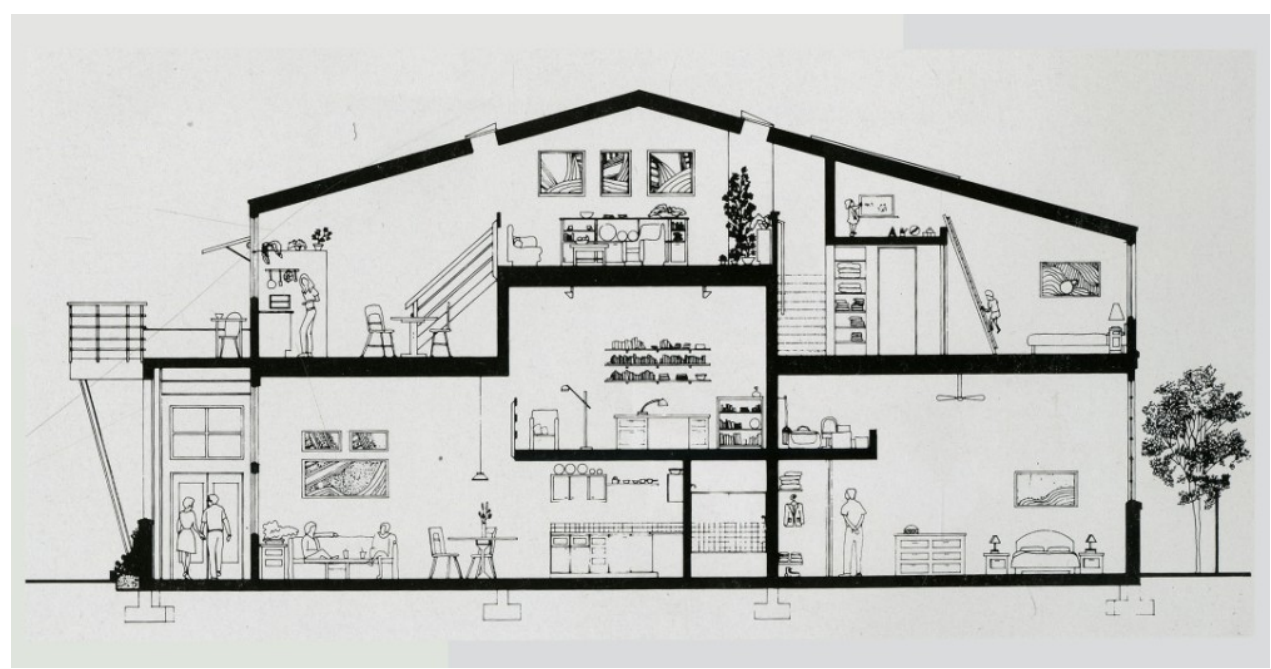




\section{Results and Impacts of the Community}

Doyle Street cohousing is known to be one of the successful models of urban infill which has influenced the surrounding neighborhood to become safe and stable. ${ }^{94}$ Study shows that community residents actively communicate with the neighborhood through various activities such as organizing community meetings, cleaning the neighborhood park, supporting political campaigns, etc. They have been involved in various committees and participated in various city activities because of their collaborative vision, revitalizing the local neighborhood. In addition, the community often hosts various events and meetings in the common house which is a convenient location within the neighboring surroundings. ${ }^{95}$ This is a model of an environmentally sensitive and an appropriately scaled multi-family development, " $a$ great contribution to the town". 96

\section{3- WindSong, British Columbia, Canada}

\section{The Design}

Located in a suburban environment and surrounded by natural greenery, a one-hour drive southeast of Vancouver, WindSong cohousing is within a short distance to the urban centre. ${ }^{97}$ Access to public transportation is in a close walking distance from the community. The project is recognized as the most environmentally responsive housing project in Canada on the basis of preserving two thirds of the site natural habitat and the existence of extensive shared

\footnotetext{
94 McCamant, Kathryn. "Cohousing Communities: A Model for Reinvigorating Urban Neighborhoods"

95 Ibid.

96 McCamant, Durrett, Creating Cohousing: Building Sustainable Communities, 152

97 Ibid., 184
} 
facilities along with small homes on the site. ${ }^{98}$ Demographically, the community is multigenerational but not entirely diverse, however it includes members with diverse skills sharing their proficiency with the community such as an accountant, architect, doctor, instructor, electrician, etc. ${ }^{99}$ This diversity of expertise is a valuable social characteristic resulting in a selfcontained and independent community.

There are 34 townhouse units on the corner of the site with an average dwelling size of $115 \mathrm{sqm}$. The unit sizes are much smaller than typical housing units, for example $93 \mathrm{sqm}$ for a three-bedroom dwelling. ${ }^{100}$ The common house is located between the two residential blocks each with a glass-covered pedestrian street of $110 \mathrm{sqm}$. It includes a workshop and shared equipments that are used by the members to limit consumption and preserve resources. ${ }^{101}$ Residential dwellings are placed and accessed around the central atrium which provides ventilation in summer and passive solar heating in winter temperatures. ${ }^{102}$ The atrium is completed with furniture and plants creating a 'public realm' that is discernible from distinct residents through color and architectural attributes. The energy efficiency and sustainability features are incorporated in the design: environmentally friendly building materials, small clustered dwelling units, and a glass covered pedestrian street. It has also preserved around 16,187 sqm of natural greenery and has organic vegetable gardens. ${ }^{103}$

\footnotetext{
${ }_{98}$ Meltzer, Sustainable Community: Learning from the Cohousing Model, 30

${ }^{99}$ Ibid., 31

${ }^{100}$ McCamant, Durrett, Creating Cohousing: Building Sustainable Communities, 186

${ }^{101}$ Ibid., 187

102 Ibid., 186

Meltzer, Sustainable Community: Learning from the Cohousing Model, 30

103 "Homes \& Environs" http://windsong.bc.ca/homes_environs/index.php
} 
- 34 dwelling units of one, two, three, and four-bedroom

- a common house including a dining room, a kitchen, lounge, children room, teen room, craft room, a workshop, laundry, office space, and a guest room

Windsong Cohousing

Langley, B.C., Canada

Status: Completed

Established: 1996

Site: Suburban

Site area: $23,835.98 \mathrm{~m} 2$

Common area: $557 \mathrm{~m}^{2}$

Architect: Davidson, Yuen \& Simpson

Development: New development

Tenure: Condominium

Design: 34 townhouse units, 1 common house

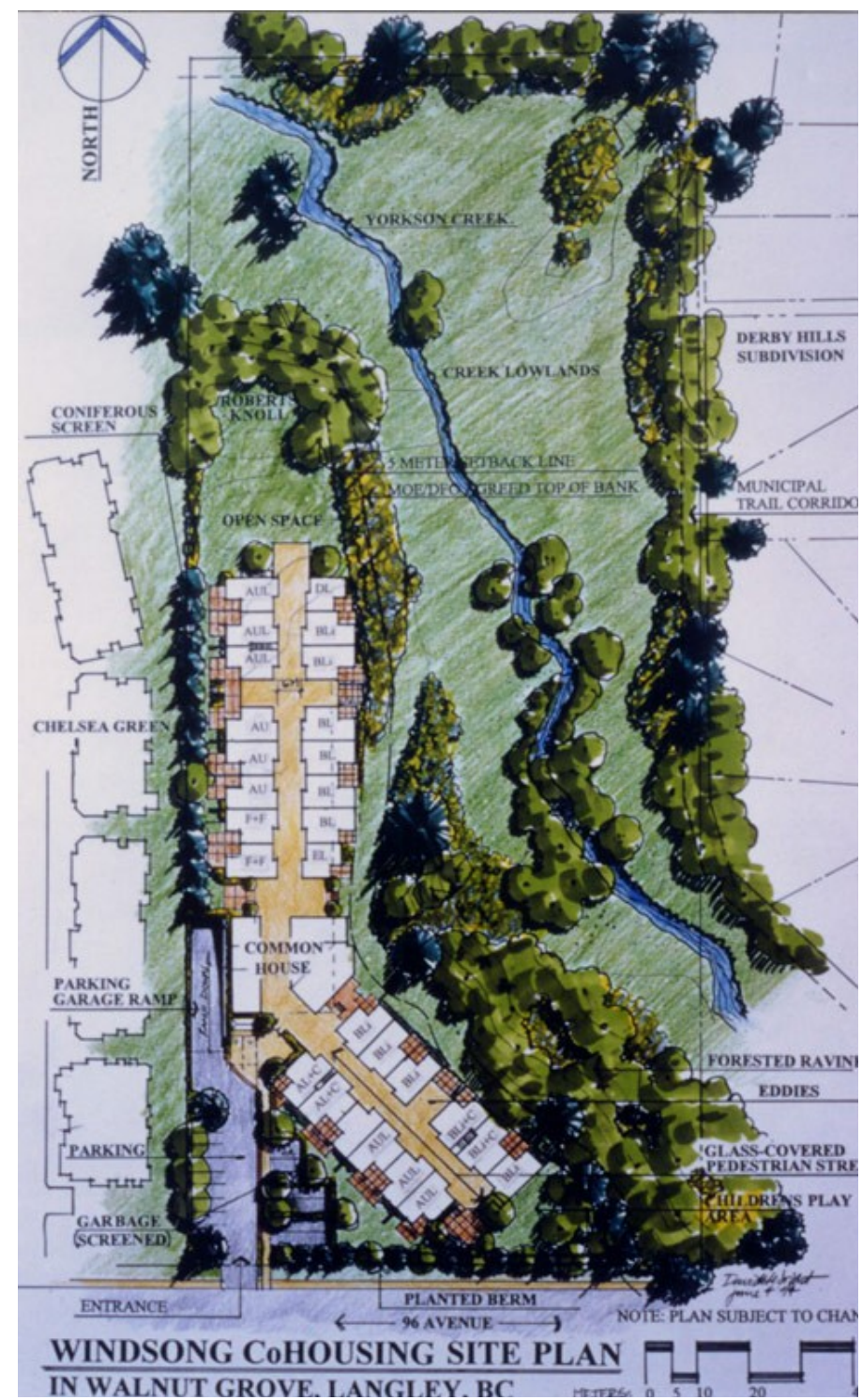

Figure 20: Site plan. Image courtesy of McCamant \& Durrett Architects http://www.cohousingco.com/projects/windsong-cohousing/ 


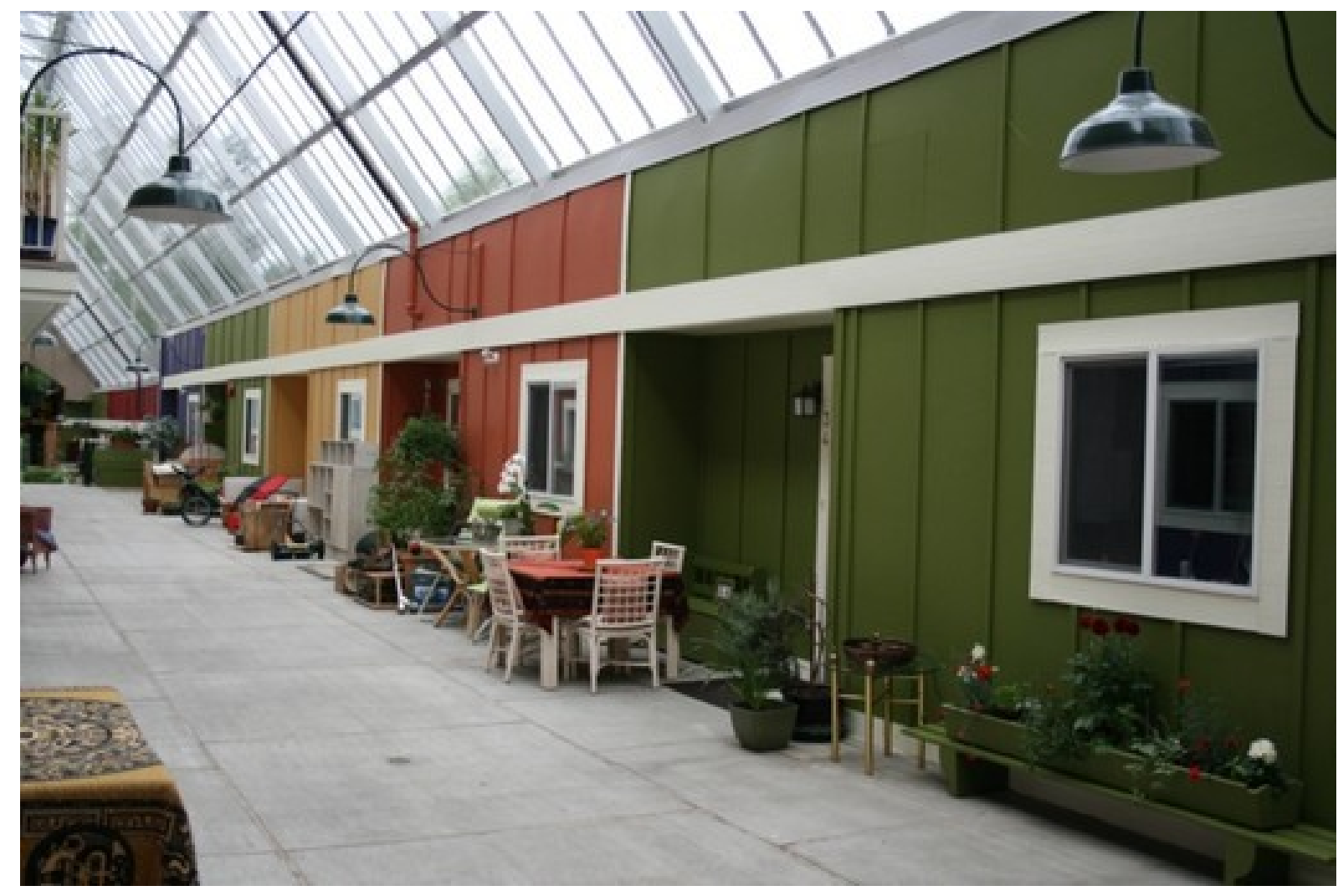

Figure 21: Glass covered pedestrian street. Image courtesy of WindSong Cohousing Community http://windsong.bc.ca/index.php
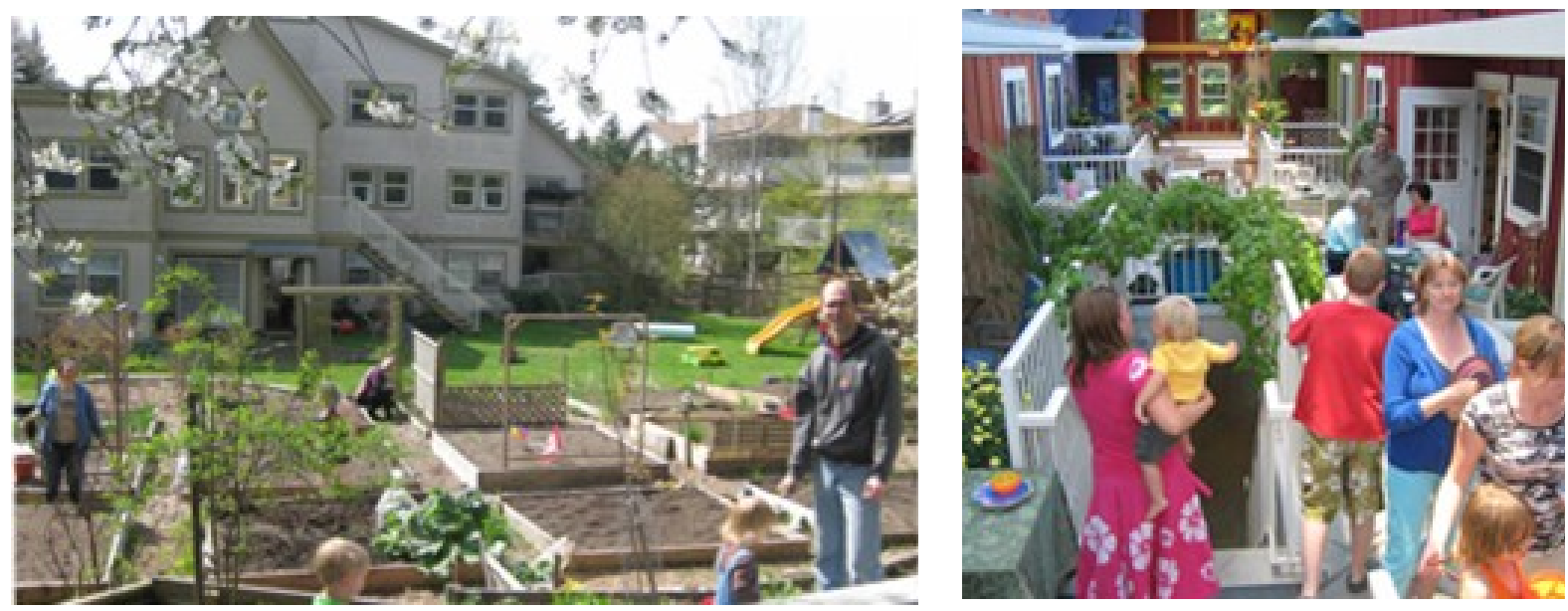

Figure 22: Outdoor gardening (left), community gathering (right). Image courtesy of WindSong Cohousing Community http://windsong.bc.ca/index.php 


\section{Results and Impacts of the Community}

WindSong cohousing is a supportive community where members have a book club, a seasonal choir, a life purpose cycle and other group activities as well as collective fun through music and performance. The community also has vegetable gardens and recycling system which benefit their sustainable lifestyle. In addition, an important characteristic of WindSong cohousing is the effort they devote to effective communication other than informal interactions as they have established variety of exchange of information methods such as a newspaper, bulletin boards, and an internet service to broadcast important messages for example meetings' minutes. ${ }^{104}$ Furthermore, the methods of saving energy and resources that are used by the members for a sustainable and economical lifestyle illustrate how group efforts and commitment to ongoing collaboration benefit the community and, in a wider context, can educate other people about "a positive alternative to single-family living". ${ }^{105}$

\section{4- Quayside Village, British Colombia, Canada}

\section{The Design}

The award winning cohousing project is situated in a vibrant urban area in the City of North Vancouver with a fifteen-minute seabus ride from Vancouver. ${ }^{106}$ This multi-generational community is located in downtown Vancouver, close to public transit and neighboring services such as libraries, a hospital, a theater, a food market, retail stores, public/private schools, etc. Community centers and parks are also located nearby. In addition, there are many restaurants

\footnotetext{
104 Meltzer, Sustainable Community: Learning from the Cohousing Model, 33-34

105 McCamant, Durrett, Creating Cohousing: Building Sustainable Communities, 188

106 "Quayside Village" https://sites.google.com/site/quaysidevillage/home
} 
with variety of international foods within ten blocks from the community. Furthermore, the cohousing community is very close to the North Shore Mountains, where mountain biking, hiking, and skiing facilities are available. ${ }^{107}$

The design of Quayside Village integrates many environmentally conscious features. The construction materials were mostly recycled from the original houses on site including wood doors, stained glass windows, and hardwood floors, which were incorporated in the design of the common areas and the residential interior. It also utilizes a grey-water recycling system that retains and recycles water from sinks, showers, and laundry for reuse in washrooms. ${ }^{108}$ Residential units range in size and types of apartment or townhouse with an average dwelling size of $80 \mathrm{sqm} .{ }^{109}$ There are four homes and one rental unit that are qualified as the affordable housing by BC Housing, the homes were sold $20 \%$ below market price and are up kept through specific contracts and the rental unit was held and maintained by the community. ${ }^{110}$ Overall, the design is comprised of the following: ${ }^{111}$

- 19 residential units in one and two-bedroom flats and two and threebedroom townhomes

- 1 rental unit of two-bedroom that is an accessible residence

107 "Lower Lonsdale" https://sites.google.com/site/quaysidevillage/neighbourhood

108 McCamant, Durrett, Creating Cohousing: Building Sustainable Communities, 192 "Detailed Community Info" http://www.cohousing.ca/detailed.htm

109 Meltzer, Sustainable Community: Learning from the Cohousing Model, 20

110 "Homes" https://sites.google.com/site/quaysidevillage/homes

111 "Common Space" https://sites.google.com/site/quaysidevillage/commonspace

"Quayside Village” http://www.cohousingconsulting.ca/proj\%20Qv.html 
- the common area including a kitchen, a lounge area, a dining area, a shared office, a draft room, a guest room, an accessible bathroom, and a laundry area, and a rooftop deck with a quite reading area and a meditation room

- an urban courtyard as an inner crossroad, a place to meet and interact

- vegetable gardens and green spaces

- commercial space accommodating a convenience store

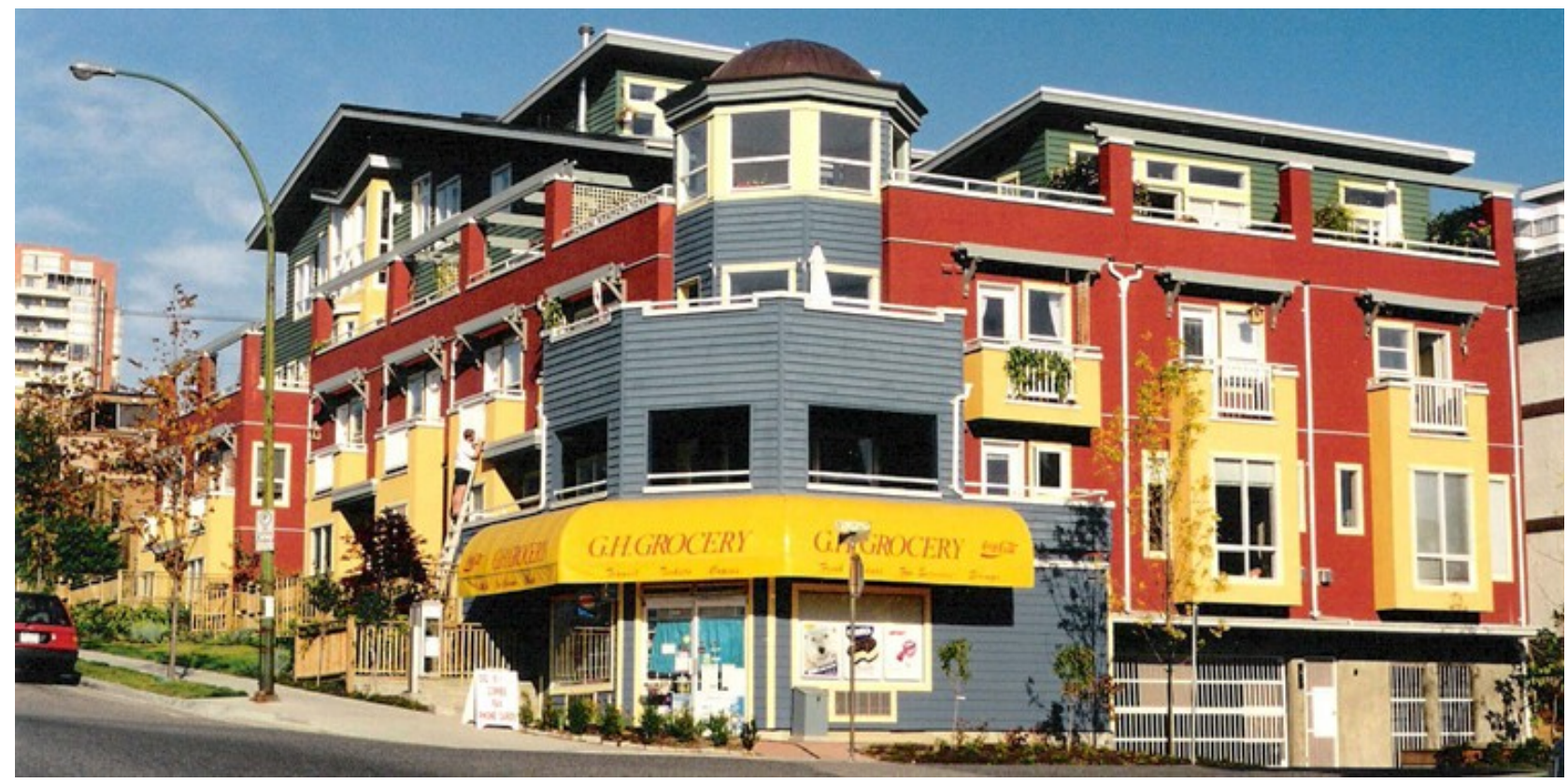

Figure 23: Quayside Village cohousing front view. Image courtesy of Cohousing Development Consulting http://www.cohousingconsulting.ca/proj\%20Qv.html 
Quayside Village Cohousing

North Vancouver, B.C., Canada

Status: Completed

Established: 1998

Site: Urban

Site area: $1,011.71 \mathrm{~m}^{2}$

Common area: $240 \mathrm{~m}^{2}$

Architect: The Courtyard Group

Development: New development

Tenure: Condominium

Design: 19 apartment/townhome units, 1 common house

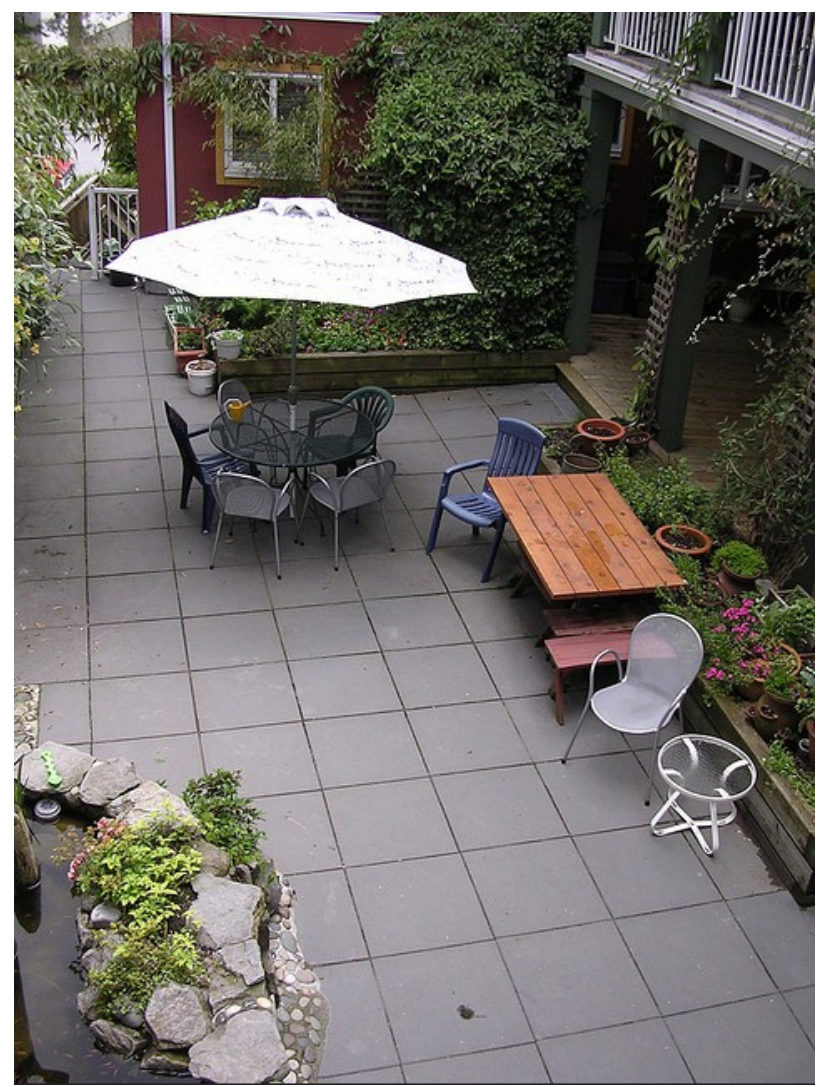

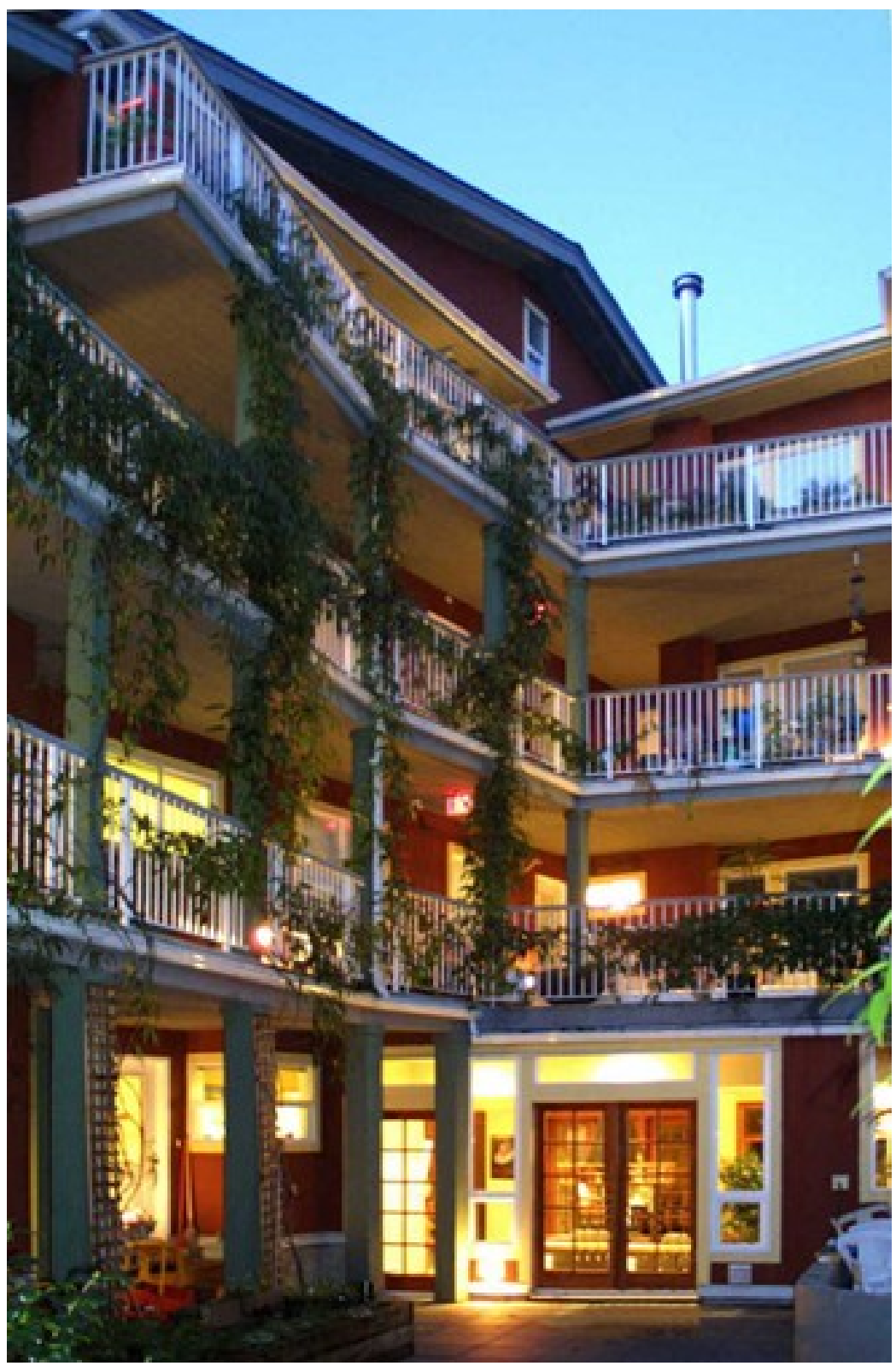

Figure 24: Residential units view (top). Image courtesy of Cohousing Development Consulting http://www.cohousingconsulting.ca/proj\%20Qv.html

Figure 25: Shared courtyard (left). Image courtesy of Quayside Village Cohousing https://sites.google.com/site/quaysidevillage/photoalbum 


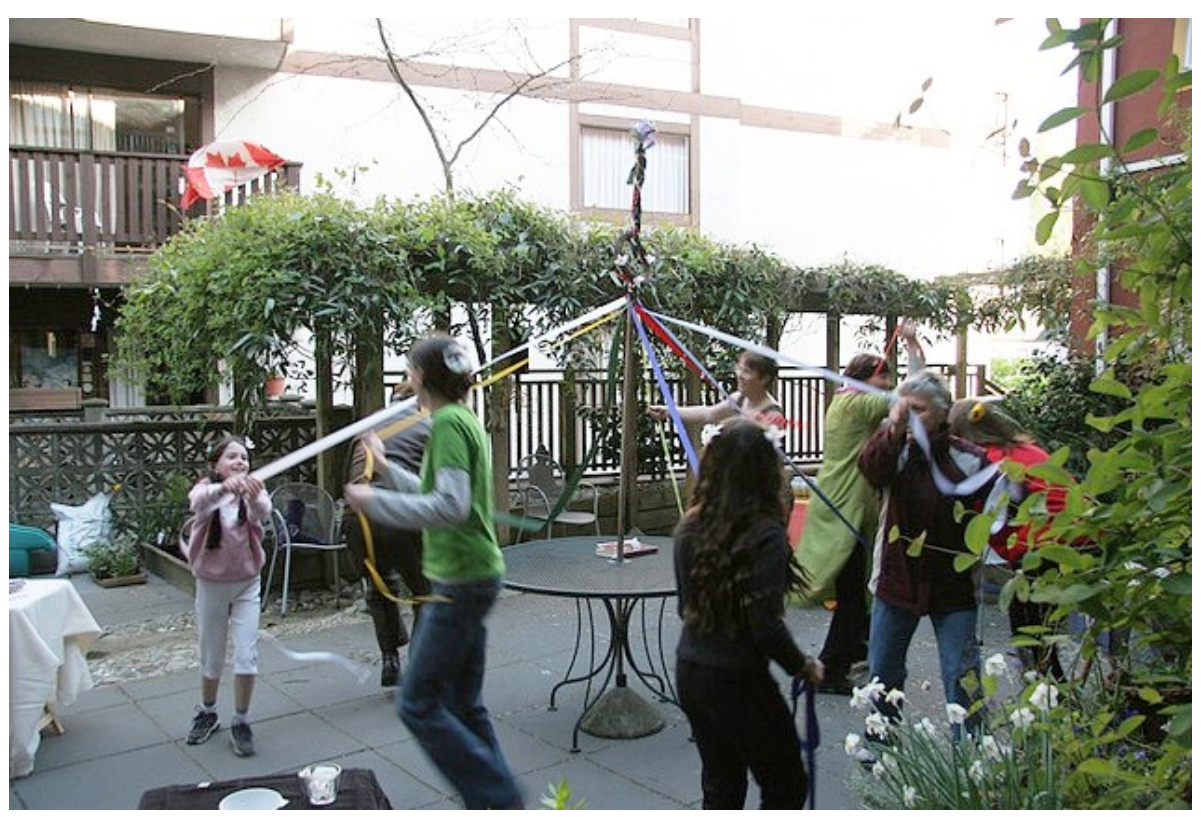

Figure 26: Community life. Image courtesy of Quayside Village

Cohousing https://sites.google.com/site/quaysidevillage/photoalbum

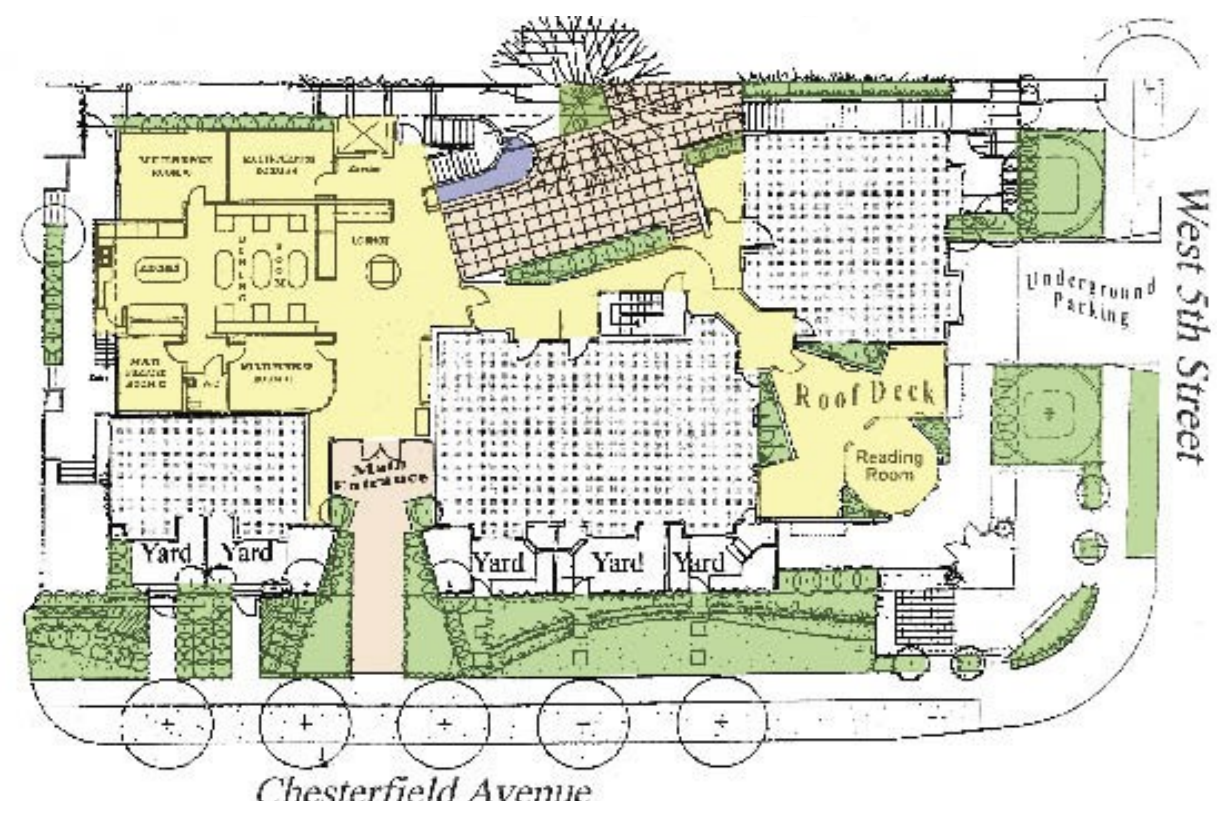

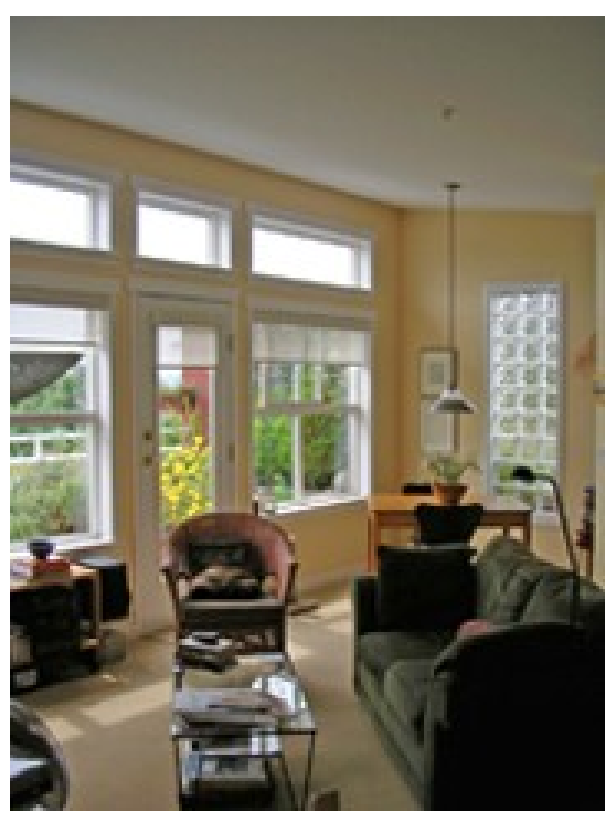

Figure 27: Townhome interior view. Image courtesy of Cohousing Development Consulting http://www.cohousingconsulting.ca/proj \%20Qv.html

Figure 28: Common spaces and gardens layout. Image courtesy of The Sea-to-Sky Green Guide http://www.seatoskygreenguide.ca/ items/quayside_village_cohousing 


\section{Results and Impacts of the Community}

Quayside Village cohousing shows that a very well-functioning community can be created out of a compact urban site of $1 / 4$ acre with the opportunity of residents' participation in the design and development process. This community was developed suited for moderate income individuals because the equity contributions of members was set between 15 to 20 per cent of total project cost and municipal authorities assisted the project to become economically viable. ${ }^{112}$ This is a collaborative residential community that is safe, affordable, accessible, and sustainable where sharing enhances affordability by reducing daily household expenses such as maintenance, child care, laundry, and etc.

\section{5- Terra Firma, Ottawa, Ontario, Canada}

\section{The Design}

Known as the only completed cohousing community in Ontario, Terra Firma is a very small cohousing project that is located in an urban environment close to Rideau Canal in the City of Ottawa. The project started by a group of future residents in 1997, when they created the community through retrofitting six homes in two adjacent townhouses in the center of the city and renovated the buildings to fit their shared life style. The community has diverse multigenerational inhabitants living in 7 residential units. The common space and the seventh unit were afterward built in the site between two buildings as an infill new development. The property also has combined back yards, where the shared facilities exist. A solar hot water

\footnotetext{
112 "Quayside Village Cohousing” https://www.cmhcschl.gc.ca/en/inpr/afhoce/afhoce/afhostcast/afhoid/cohode/cost/cost_005.cfm
} 
installation is also added to provide heat and hot water to the common space and the additional unit in order to achieve a sustainable design. The common house is used to host variety of events in the community and with the neighborhood. Furthermore, nearby neighbors join the community to share meals twice a week. The shared spaces are as follow: ${ }^{113}$

- a common house including a kitchen, lounge area, a guest room, bathroom, and sauna

- a common yard including play structures, sitting area, a tree-house, gardens, storage spaces, and bicycle area

\section{Terra Firma Cohousing}

Ottawa, Ontario, Canada

Status: Completed

Established: 1999

Site: Urban

Site area: $2,023.43 \mathrm{~m}^{2}$

Common area: $116.12 \mathrm{~m}^{2}$

Development: Resident-led

Development: Retrofit

Tenure: Condominium

Design: 7 condominium units in two three-door joined townhouses, 1 common house

113 "Detailed Community Info" http://www.cohousing.ca/detailed.htm 


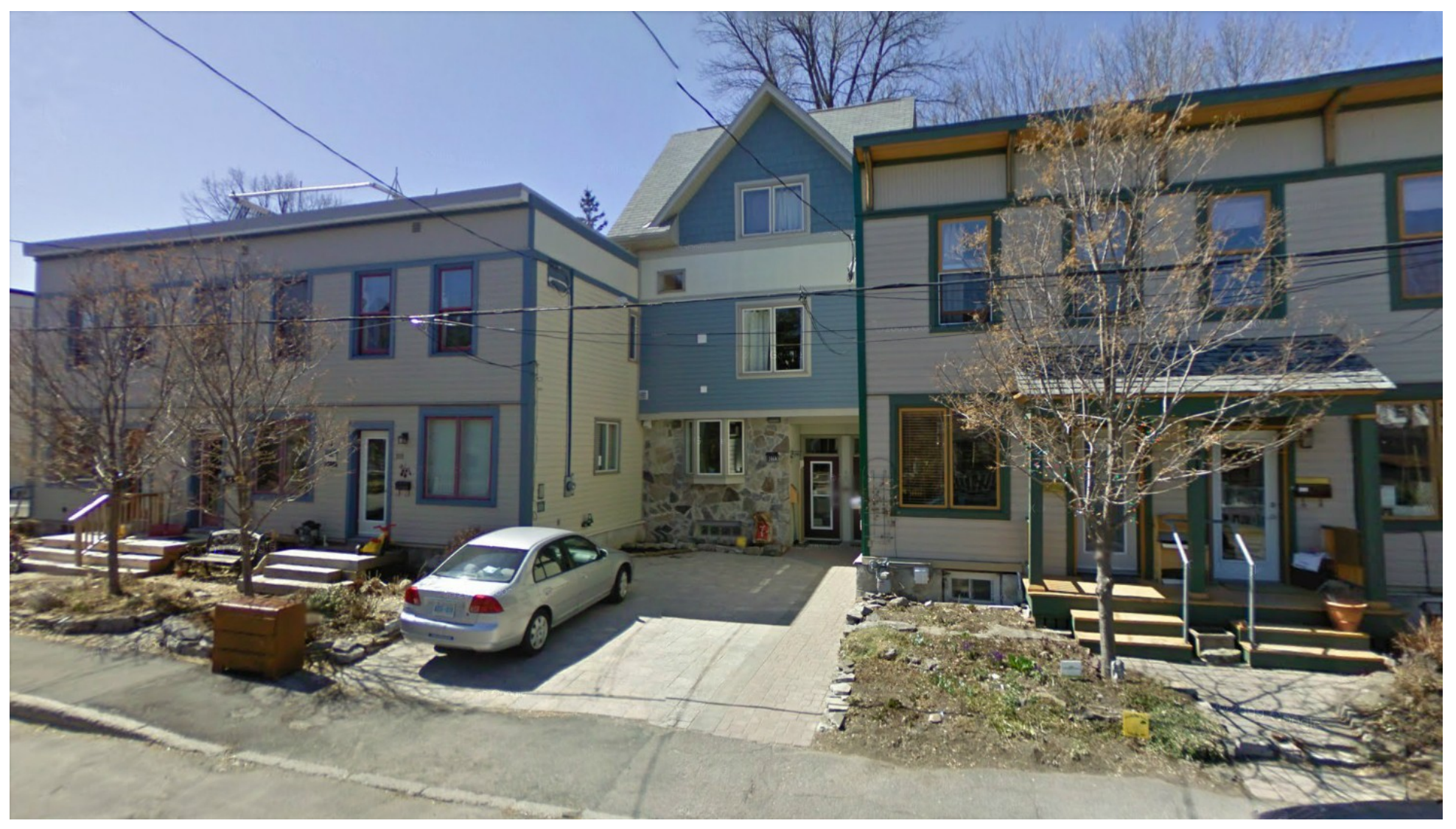

Figure 29: Terra Firma cohousing site front view from Drummond Street showing two townhouses with the infill common house addition. Image by author

\section{Results and Impacts of the Community}

Terra Firma is built so that families dwell in a supportive community; it is like "rebuilding a village" as one of the residents states. ${ }^{114}$ A sustainable life style is created for the residents using shared facilities such as community gardens and children's play area for an urban living in the centre of Ottawa.

\footnotetext{
${ }^{114}$ In an interview with residents of Terra Firma, "Co-housing in the Centre of Ottawa"
} http://www.cbc.ca/player/Radio/Local+Shows/Ontario/ID/2435627310/ 


\subsection{Conclusion}

Nowadays, cohousing is a well-established housing model in Denmark. The concept has been developed over the years and its benefits are now highly recognized among people to the point that in new communities there has been a decrease in the average size of private dwellings while shared facilities have increased proportion and significance. ${ }^{115}$

In contrast, in United States and Canada, the overall public to private proportion is not as well-developed as in Denmark. With regards to the analysis of the presented case studies and research on other existing cohousing communities, Table 3 demonstrates that the ratio of total public areas to total average private areas. From the proposed community-oriented design, this ratio is also added in the chart (detail data is presented in Table 5 and Table 6). Data comparison between the proposed design and the existing communities demonstrates noticeable differences in the results which are to the fact that the proposed design incorporates small scale residential units while includes extensive shared areas.

The data calculation of the design proposition shows the total interior public space of $1163 \mathrm{~m}^{2}$ in which $47 \%$ is the public spaces and $53 \%$ is the semi-private spaces. The ratio analysis demonstrates that the design contains $27 \%$ shared spaces between residents and the addition of $24 \%$ shared spaces between residents and public in relation to the residential units.

115 Milman, Danny. "History of Cohousing" http://www.cohousing.ca/history.htm 


\begin{tabular}{|c|c|c|c|c|c|c|c|}
\hline Urban Project & $\begin{array}{c}\text { Site Area } \\
\mathbf{m}^{2}\end{array}$ & $\begin{array}{c}\text { Public } \\
\text { Area } \\
\text { m }^{2}\end{array}$ & $\begin{array}{l}\text { Number } \\
\text { of Units }\end{array}$ & $\begin{array}{c}\text { Average } \\
\text { Unit Size } \\
\text { m }^{2}\end{array}$ & $\begin{array}{c}\text { Total } \\
\text { Average } \\
\text { Floor } \\
\text { Area of } \\
\text { Units } \\
\text { m }^{2}\end{array}$ & $\begin{array}{c}\text { Total } \\
\text { Floor } \\
\text { Area of } \\
\text { Building } \\
\text { m }^{2}\end{array}$ & $\begin{array}{c}\text { Public to } \\
\text { Private } \\
\text { Ratio } \mathbf{m}^{2}\end{array}$ \\
\hline Swan's Market & $1,011.71$ & 465 & 38 & 95 & 3,610 & 4,075 & $12.88 \%$ \\
\hline Doyle Street & $1,214.06$ & 195.09 & 12 & 100 & 1,200 & $1,395.09$ & $16.25 \%$ \\
\hline WindSong & $23,835.98$ & 557 & 34 & 115 & 3,910 & 4,467 & $14.24 \%$ \\
\hline Quayside Village & $1,011.71$ & 240 & 20 & 80 & 1,600 & 1,840 & $15 \%$ \\
\hline Design Proposition & 2,800 & 1163 & 25 & 90 & 2245 & 5019 & $24 \%+27 \%$ \\
\hline
\end{tabular}

Table 3: The spatial analysis of the proposed designed community compared to the studied cohousing developments 


\section{Section III: Design Exploration}

\section{Design Methodology of a Community-oriented Residential Complex}

\subsection{Thesis Objectives and Design Criterions}

The purpose of this research is to investigate how the architectural design of residential buildings can create and strengthen the sense of belonging. This was accomplished by deep analysis of practical principles, architectural elements, and social patterns of cohousing communities through precedent studies in order to design for social connectivity, creating community-oriented life as the place where 'home' is.

By utilizing the design features and main principles of cohousing scheme, a mixed-use community-oriented residential building, is designed to encourage collaborative and co-operative living style for its inhabitants. In this thesis, the community is named 'Co-housing+' because it is derived from the elements of cohousing model along with further contributions to this residential model. The design intention is to provide a balanced private and public life through spatial layout and buffer zones for optimal social interactions emphasizing the following: 
- Privacy is achieved through private dwellings where inhabitants are able to be within their personal enclosed physical boundary.

- Companionship comes to existence in the community through open and collective spaces and by sharing on-site facilities, enabling inhabitants to socialize close to "home" to have the sense of community.

- Connectivity, both physical and social, is attained by intentional design for social interactions. The physical connection exists between public, private, and semi-private spaces and through horizontal and vertical circulations within the building. The social connectivity is created by the inhabitants through participation in community life and is promoted by premeditated design components.

- Security, as one of the most important aspects, is provided by enclosed spaces, secure entrances, and the surveillance opportunities within the building.

- Internal community is created through the internal semi-private spaces and buffer zones for the inhabitants.

- External community that exists within the physical limit of the open ground level and beyond that, where the city enters the community-oriented building. The first level is meant to be a publicly accessible space to extend social support networks to the larger neighboring community. 


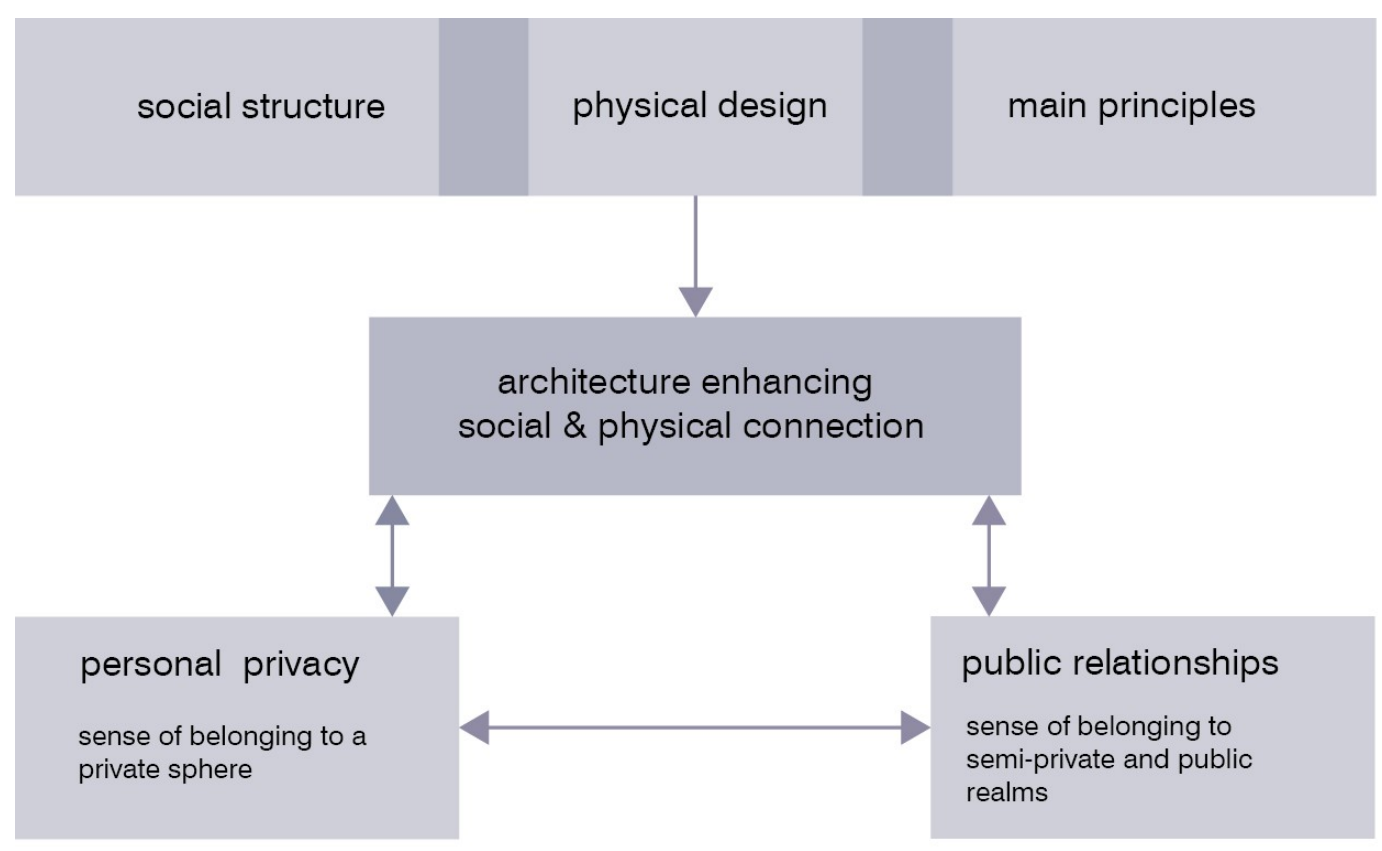

Figure 30: Cohousing design aspects consideration with regards to section 3.2. in order to design an architectural edifice that promotes community

The proposed design is derived from the social and spatial aspects of the case studies and research. Although the development assumption is with regard to the developer-led approach due to the fact that no real client exists, spatial features are based on cohousing design principles and social aspects that are provided to meet community's needs and values. Hence, it should be considered that residents' inputs and involvement in the process is highly important and required in order to design for specific groups' needs. 


\section{Co-housing+: Community-oriented Residential Complex}

\begin{tabular}{|c|c|}
\hline $\begin{array}{l}\text { Ownership } \\
\text { structure }\end{array}$ & $\begin{array}{l}\text { every owner has private ownership of the residential unit and shared ownership of common } \\
\text { amenities, guest units are maintained by the community, rental and affordable units are } \\
\text { maintained by the developer }\end{array}$ \\
\hline Purpose & $\begin{array}{l}\text { creating a neighborhood that satisfies residents' needs for a balanced life style in private } \\
\text { homes and community environment }\end{array}$ \\
\hline Owners & diverse multi-generational residents with a range of household incomes \\
\hline $\begin{array}{l}\text { New } \\
\text { members }\end{array}$ & $\begin{array}{l}\text { the initial recruitment is done by the community or by the developer under the acceptance of } \\
\text { the community members. In the case that a unit is sold by an owner, the seller should inform } \\
\text { the community and educate the buyer }\end{array}$ \\
\hline $\begin{array}{l}\text { Policies and } \\
\text { regulations }\end{array}$ & $\begin{array}{l}\text { non-hierarchical decision making by all the community members, a consensus decision } \\
\text { process }\end{array}$ \\
\hline Development & a developer-led process \\
\hline $\begin{array}{l}\text { Financing a } \\
\text { unit }\end{array}$ & easy to get a mortgage on a unit \\
\hline Resale value & $\begin{array}{l}\text { the value is at the market price except the affordable units that are kept within a fixed value by } \\
\text { covenants }\end{array}$ \\
\hline $\begin{array}{l}\text { Design } \\
\text { components }\end{array}$ & $\begin{array}{l}\text { private residential units, rental units, affordable units, and extensive shared facilities through } \\
\text { social design for optimal residents' interaction }\end{array}$ \\
\hline Social aspect & highly community-oriented design for optimal social interactions among residents \\
\hline
\end{tabular}

Table 4: Overall characteristics of the proposed community-oriented residential complex derived from the cohousing model (refer to Table 1) 


\section{Site Analysis}

\subsection{Site Selection Rationale}

As it is presented in sections 4.2. and 3.1., cohousing communities have been developed in recent decades in North America and not as many communities exist when compared to Denmark. Williams states that in United States, the slow adoption and development rate is due to the fact that this model is somehow less compatible with the current system of lifestyle and values. ${ }^{116}$ In Canada, cohousing is a relatively new residential model which has been slowly growing and evolving by new developments in various cities. It is also apparent that the concept of cohousing is not a well-recognized residential model mainly because of the fact that the semicommon living style is not well known and understood within the society as yet. However, research suggests that if the benefits of community-oriented life are experienced and advertised, with the emergence of new values of community ethics, environmental sensitivity, and social supports this model can become increasingly popular in our society. ${ }^{117}$

In Toronto, in particular, a cosmopolitan city, consumer culture has impacted people's lifestyle. Broadly speaking, the city represents the noticeable aspects of this research about consumerism, separation, lack of social relationships, and common values, and the need for a sense of belonging. For this reason, Toronto is chosen as the site of the proposed design because it would benefit from this type of residential development for people who look for leaving in socially oriented neighborhoods.

\footnotetext{
116 Williams, "Predicting an American Future for Cohousing", 279

117 Ibid.
} 


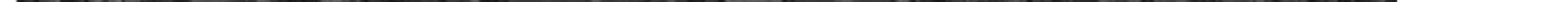




\subsection{Site Study}

The selected site is located in North York region, taking one urban block that includes Willowdale Park and North York Tennis Club. ${ }^{118}$ The site affords the convenience of living in walking distance to many public programs including a public library, cafes, restaurants, art shops, entertainment centers, grocery stores, shopping malls, schools, parks, extensive public transportation, and altogether the vibrant city life. The design is proposed to be placed on a site area of $40 \times 70 \mathrm{~m}$ (total of $2800 \mathrm{~m}^{2}$ ) taking over the smaller existing parking lot located on the North West. This location is strategically selected mainly based on the existing park and the tennis club that makes the urban context highly valued and alive. The greenery of the park is extended to the building's public open space, creating a pathway from the public park to the community in order to attract the surrounding neighborhoods and blend them within the community. This is the threshold where the city enters the community through a reciprocal exchange of spaces and support sustaining one another.

118 City of Toronto http://www1.toronto.ca/wps/portal/contentonly?vgnextoid=3fcfdada600f0410VgnVCM10000071d60f89RCRD\&vg nextchannel=1309a5dc09311410VgnVCM10000071d60f89RCRD

This is a Community Tennis Club, an outdoor tennis facility that only operates during summer from April to October. Generally, the Community Club Sites are owned by the City of Toronto while they are privately operated by a nonprofit Community Tennis Club and its volunteers. 


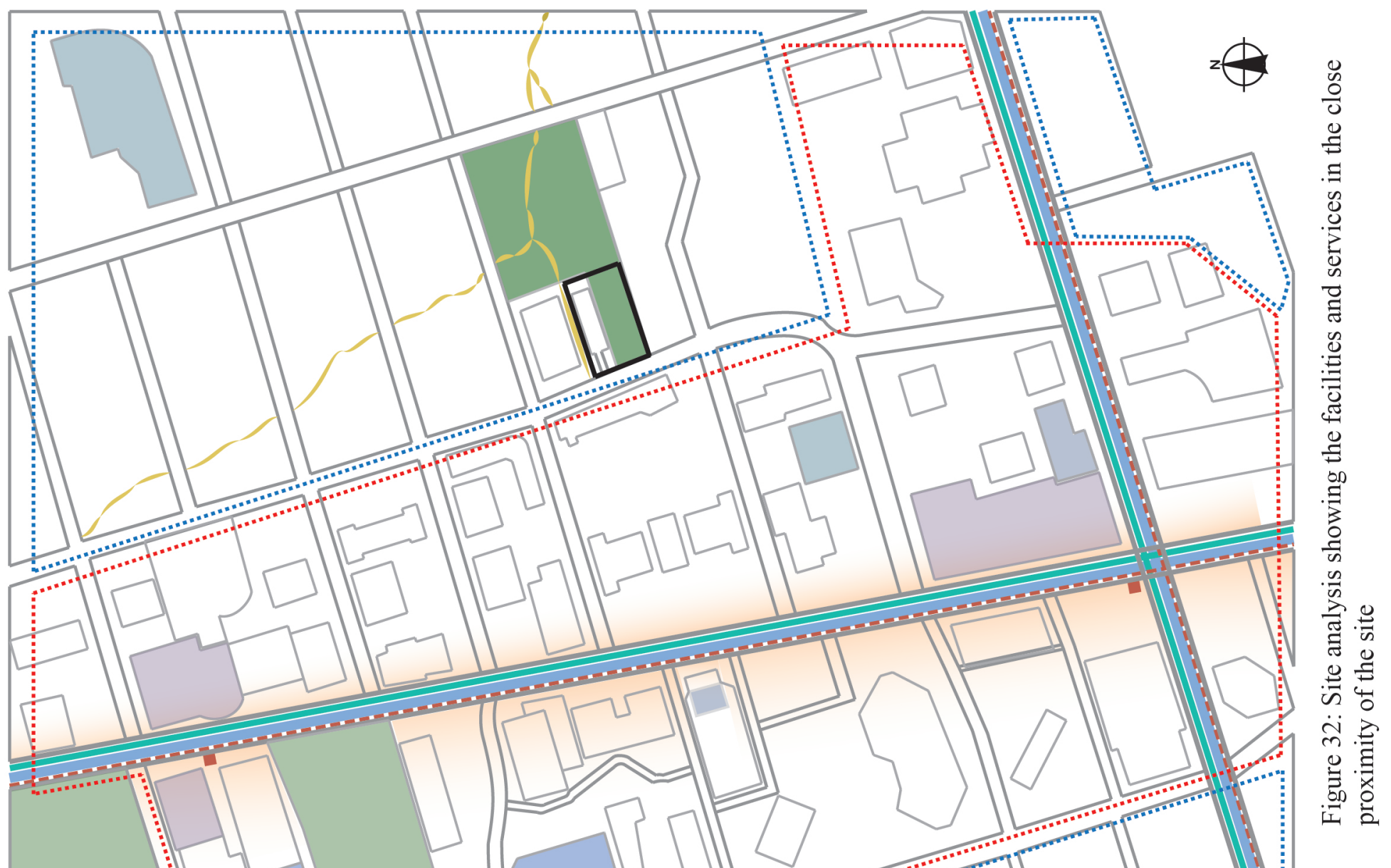

口
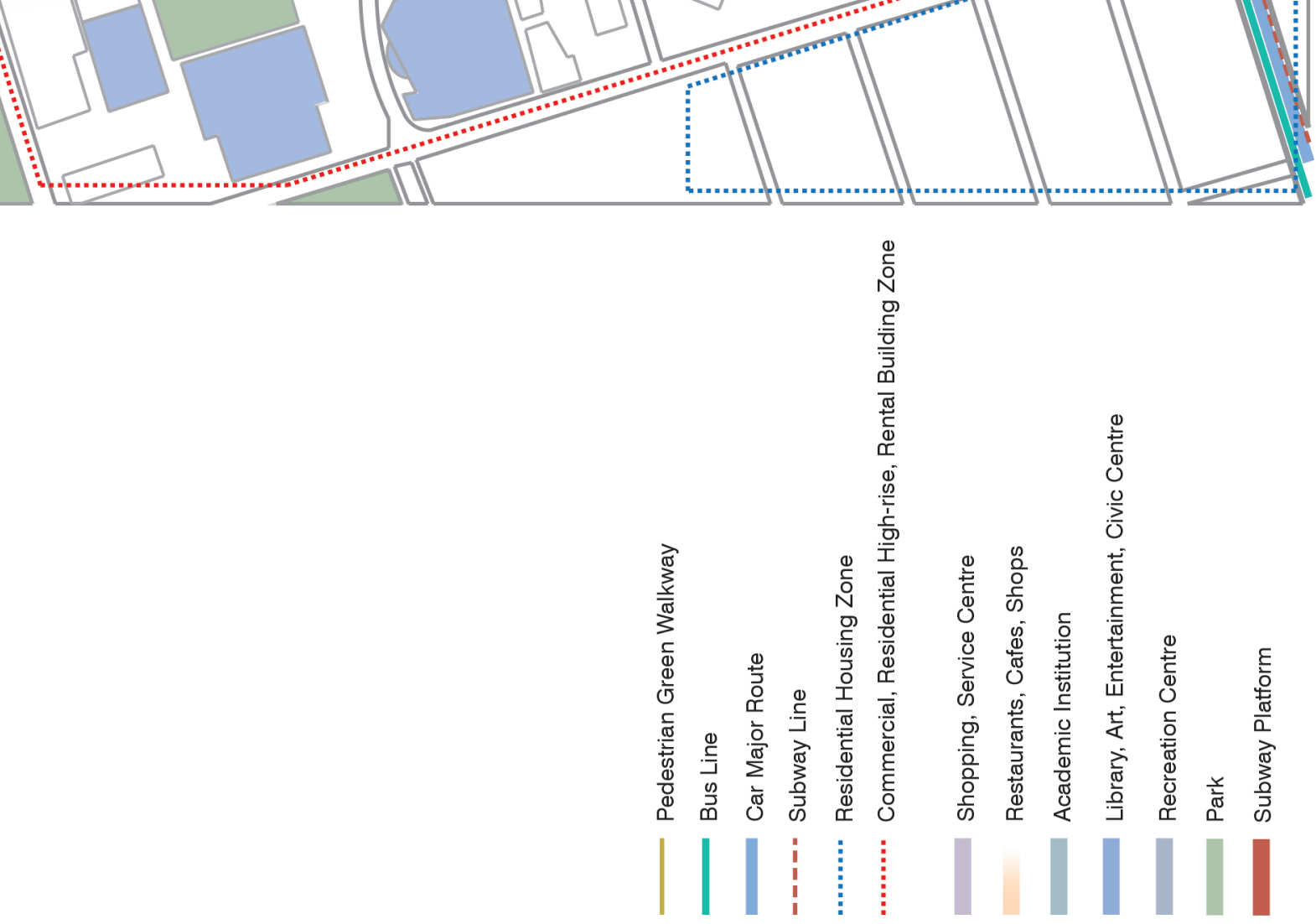


\section{Proposition}

\subsection{Program Analysis}

\section{The Users}

The design intends to provide a balanced mix of privacy and community for multigenerational diverse families ranging in age and nationality. The basis of the design is creating spaces that are convenient, pleasant, accessible, and sustainable taking into consideration the users: singles, families with kids, and seniors.

\section{The Program}

The proposed urban community-oriented residential complex, 'co-housing+', creates the opportunity for a sense of belonging and a sense of community in a self-contained neighborhood through the design of spaces for social interactions:

- Private space (for residents) includes apartment units for ownership and renting (market price and affordable price) varying in size and type; each unit comprises of a bedroom/s or a den space, a dining room, a living room, a kitchen, and a bathroom/s.

- Semi-private space (between residents) encompasses buffer zones such as connecting pathways, green spaces, vegetation gardens, and verandas, and also shared facilities among residents: an office, a meeting room, lounges (social spaces), a children playroom, a children craft room, a meditation room, storage spaces, underground parking, a guest 
residency that includes a living space with a bathroom, and the common unit that includes a dining room, a living room, and a kitchen. From the buffer zones and most of the shared spaces, residents have views over the public spaces such as courtyard in order to maintain a connection to the community and to offer a sense of security.

- Public space (between residents and public) contains the common outdoor courtyard space at the urban level and the ground floor amenities shared between residents and available for public access: a café, a gym, a multi-purpose gallery space, a theater room, a library space, a study space, a workshop space, a greet space and a lounge area.

Table 5 demonstrates the allocated floor area and the location of each space in the building:

\begin{tabular}{|c|c|c|c|c|}
\hline Space Type & Occupancy & Number & $\begin{array}{c}\text { Floor } \\
\text { Location }\end{array}$ & $\begin{array}{c}\text { Total Net } \\
\text { Floor Area } \\
\text { m }^{2}\end{array}$ \\
\hline Visitors' Greet Space & Public & 1 & $1^{\mathrm{st}}$ & 24 \\
\hline Library & Public & 1 & $1^{\text {st }}$ & 38 \\
\hline Study Room & Public & 1 & $1^{\mathrm{st}}$ & 85 \\
\hline Workshop Space & Public & 1 & $1^{\mathrm{st}}$ & 45 \\
\hline Public Lounge & Public & 1 & $1^{\mathrm{st}}$ & 127 \\
\hline Theater Room & Public & 1 & $1^{\mathrm{st}}$ & 61 \\
\hline Multi-purpose Space & Public & 1 & $1^{\mathrm{st}}$ & 114 \\
\hline Cafe & Public & 1 & $1^{\text {st }}$ & 61 \\
\hline Exercise Room & Public & 1 & $1^{\mathrm{st}}$ & 116 \\
\hline Courtyard & Public & 1 & $1^{\mathrm{st}}$ & 577 \\
\hline
\end{tabular}




\begin{tabular}{|c|c|c|c|c|}
\hline Residents' Lobby Area & Semi-private & 1 & $1^{\text {st }}$ & 168 \\
\hline Meeting Room & Semi-private & 1 & $1^{\text {st }}$ & 51 \\
\hline Office & Semi-private & 1 & $1^{\text {st }}$ & 16 \\
\hline $\begin{array}{r}\text { Shared Dining Area \& Living } \\
\text { Room \& Kitchen }\end{array}$ & Semi-private & 1 & $2^{\text {nd }}$ & 177 \\
\hline Children Play Room & Semi-private & 1 & $3^{\mathrm{rd}}$ & 44 \\
\hline Children Craft Room & Semi-private & 1 & $3^{\text {rd }}$ & 30 \\
\hline Meditation Room & Semi-private & 1 & $4^{\text {th }}$ & 46 \\
\hline Guest Unit & Semi-private & 1 & $4^{\text {th }}$ & 22 \\
\hline $\begin{array}{r}\text { Social Spaces (Lounge \& Sitting } \\
\text { Area) }\end{array}$ & Semi-private & 7 & $2^{\text {nd }}, 3^{\text {rd }}, 4^{\text {th }}$ & 318 \\
\hline Vegetation Gardens & Semi-private & 3 & $2^{\text {nd }}, 3^{\text {rd }}, 4^{\text {th }}$ & 132 \\
\hline Patio Area & Semi-private & 3 & $2^{\text {nd }}, 3^{\text {rd }}, 4^{\text {th }}$ & 277 \\
\hline $\begin{array}{r}\text { Circulation Area (interior \& } \\
\text { exterior) }\end{array}$ & $\begin{array}{l}\text { Semi- } \\
\text { private/Public }\end{array}$ & multiple & all & 1162 \\
\hline Parking Space & Semi-private & 48 & 0 & 1401 \\
\hline Storage Space & Semi-private & 26 & 0 & 258 \\
\hline Mechanical \& Electrical Rooms & Semi-private & 1 & 0 & 34 \\
\hline $\begin{array}{r}\text { Loading \& Recycling \& Storage } \\
\text { Spaces }\end{array}$ & Semi-private & 1 & $1^{\mathrm{st}}$ & 37 \\
\hline Washroom & $\begin{array}{c}\text { Semi- } \\
\text { private/Public }\end{array}$ & 5 & $1^{\text {st }}, 3^{\text {rd }}$ & 68 \\
\hline Balcony Area & Private & 26 & $2^{\text {nd }}, 3^{\text {rd }}, 4^{\text {th }}$ & 153 \\
\hline Studio Unit & Private & 1 & $3^{\text {rd }}$ & 43 \\
\hline 1-bedroom Unit & Private & 10 & $2^{\text {nd }}, 3^{\text {rd }}, 4^{\text {th }}$ & 696 \\
\hline 2-bedroom Unit & Private & 11 & $2^{\text {nd }}, 3^{\text {rd }}, 4^{\text {th }}$ & 1019 \\
\hline 3-bedroom Unit & Private & 3 & $2^{\text {nd }}, 3^{\text {rd }}$ & 451 \\
\hline & & & & \\
\hline
\end{tabular}

Table 5: Program details chart 
The complex consists of 25 apartment units out of which 5 units of one and two bedrooms are offered as rental units: 3 at market price and 2 at affordable price. The dwelling units include studio, one bedroom, two bedroom, and three bedroom types. Each type, except the studio unit, has multiple variations in size and design to meet the requisites of the defined users.

\begin{tabular}{|c|c|c|c|c|c|c|c|c|c|}
\hline Unit Type & $\begin{array}{c}\text { Var. } \\
\# 1\end{array}$ & $\begin{array}{c}\text { Var. } \\
\# 2\end{array}$ & $\begin{array}{c}\text { Var. } \\
\# 3\end{array}$ & $\begin{array}{c}\text { Var. } \\
\# 4\end{array}$ & $\begin{array}{c}\text { Var. } \\
\# 5\end{array}$ & $\begin{array}{l}\text { Total } \\
\text { Numbe } \\
\quad \mathbf{r}\end{array}$ & $\begin{array}{c}\text { Average } \\
\text { Unit Size } \\
\text { m }^{2}\end{array}$ & $\begin{array}{c}\text { Total } \\
\text { Average } \\
\text { Floor } \\
\text { Area per } \\
\text { Unit } \\
\text { Type } \\
\mathbf{m}^{2}\end{array}$ & $\begin{array}{c}\text { Total } \\
\text { Floor } \\
\text { Area } \\
\text { per } \\
\text { Unit } \\
\text { Type } \\
\text { m }^{2}\end{array}$ \\
\hline Studio & $\begin{array}{l}43 \mathrm{~m} \\
\text { (1) }\end{array}$ & & & & & 1 & 43 & 43 & 43 \\
\hline 1-bedroom & $\begin{array}{c}62 \mathrm{~m} \\
(2)\end{array}$ & $\begin{array}{c}65 \mathrm{~m} \\
(3)\end{array}$ & $\begin{array}{c}67 \mathrm{~m} \\
\text { (3) }\end{array}$ & $\begin{array}{l}82 \mathrm{~m} \\
\text { (1) }\end{array}$ & $\begin{array}{c}94 \mathrm{~m} \\
\text { (1) }\end{array}$ & 10 & 74 & 740 & 696 \\
\hline 2-bedroom & $\begin{array}{l}93 \mathrm{~m} \\
\text { (3) }\end{array}$ & $\begin{array}{l}88 \mathrm{~m} \\
(2)\end{array}$ & $\begin{array}{c}94 \mathrm{~m} \\
\text { (3) }\end{array}$ & $\begin{array}{c}94 \mathrm{~m} \\
\text { (3) }\end{array}$ & & 11 & 92 & 1012 & 1019 \\
\hline 3-bedroom & $\begin{array}{c}155 \mathrm{~m} \\
\text { (1) }\end{array}$ & $\begin{array}{c}179 \mathrm{~m} \\
\text { (1) }\end{array}$ & $\begin{array}{c}117 \mathrm{~m} \\
\text { (1) }\end{array}$ & & & 3 & 150 & 450 & 451 \\
\hline Total & & & & & & 25 & & 2245 & 2209 \\
\hline
\end{tabular}

Table 6: Dwelling units type, variation (with the total number of unit type of that specific variation), and floor area analysis 


\subsection{Design Documentation}

\section{Design Overview}

The design comprises of 4 diverse interconnected blocks in various sizes and scales to create a modern community-oriented residential building fostering a strong sense of belonging. It includes two 4-storey residential buildings and two 4-storey common buildings, which are connected through shared pathways, gardens, and lounge areas. Because of the compact site, residential dwelling units and the shared facilities are stacked vertically in four levels. The common blocks are located at the intersection points of the two residential blocks. All are positioned in a way to form an open courtyard within the complex in order to, as Durrett states, "create life between the buildings", to chat, to support, and to exchange. ${ }^{119}$

119 Durrett, Charles. $I^{\text {st }}$ International Cohousing Conference, 2009 http://www.youtube.com/watch?v=x0RCTqtycCY\#t=22 


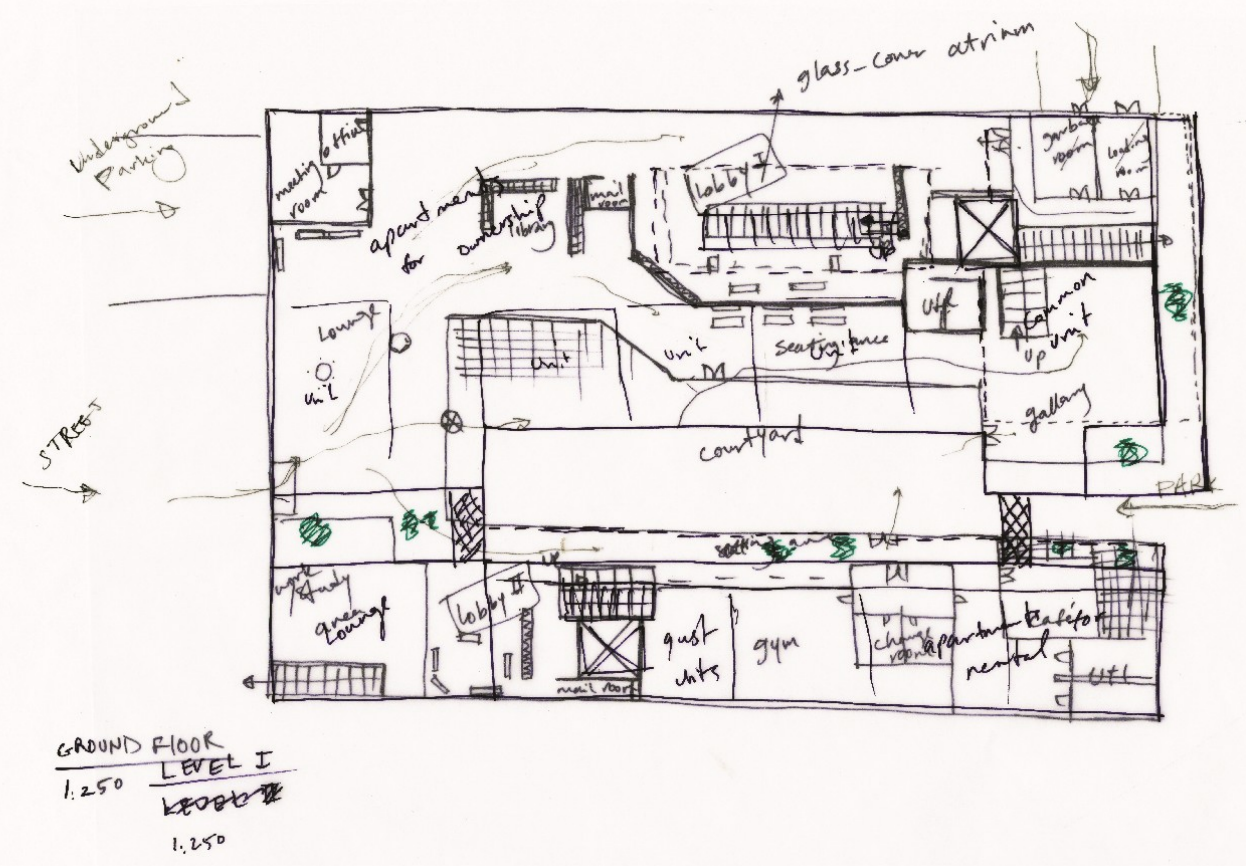

LEVEL 1 \& 2

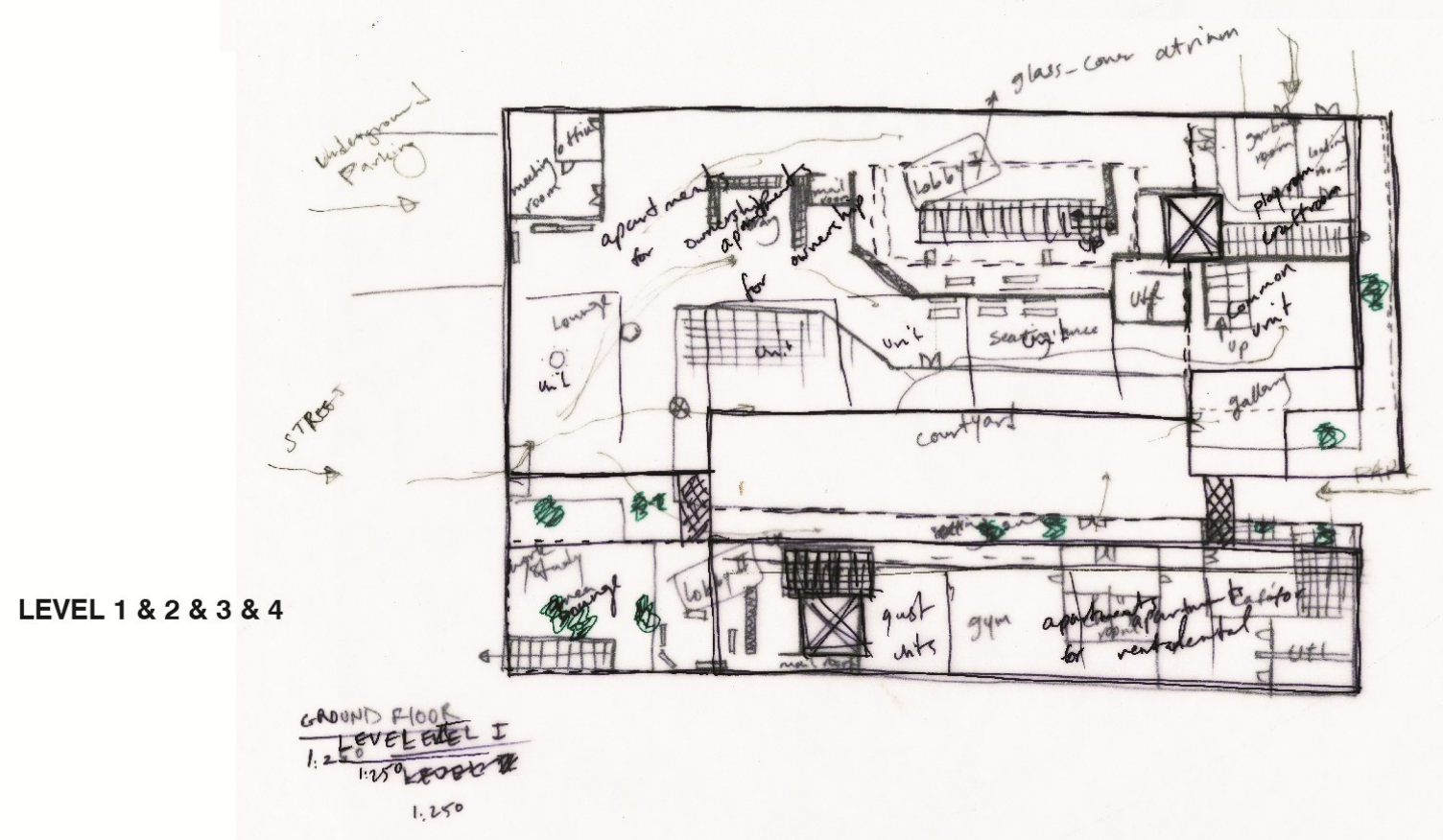

Figure 33: Initial sketches developing the complex from the public ground floor to the private residential units, the shared spaces are placed within the residents' main circulation paths 
In general, co-housing+ is designed taking into consideration the social design elements of the developed cohousing communities with additional contributions to this residential model: it redefines the public space by opening it to the surrounding neighborhood, it has extensive semi-private and public spaces in relation to the private space (studied in Table 3), it provides more rental opportunities for short or long term habitation, and it certainly can promote this residential model because of its selected context.

As research suggests when communities are more welcoming and open to the neighboring residents, neighbors gain from the social support and the exchange of information as well as this residential model and its benefits become well-recognized within the society. ${ }^{120}$ Even though, building co-housing+ on the proposed site takes away some "public" space, the community gives back by means of its public programs and social networks. Thus, the strategic site is where the new community merges with the existing local creating a greater community.

Co-housing+ incorporates specific design principles and social relation characteristics from the urban view point and from the architectonic aspect:

- site location is to increase the adoption rate of cohousing model in the city

- public access to the urban level integrates the local with the community life

- the 4-storey complex is a threshold between the high-rise condominium zone and the low-rise residential townhouse zone, prominently revealing an archetype cohousing design that creates a greater community

${ }^{120}$ Williams, "Predicting an American Future for Cohousing", 280 
- more space is allocated for shared amenities both in public space and semi-private space all throughout the building;

- rental units (market price and affordable price) are available within the private space;

- the buffer zones are designed for a smooth transition between private dwellings, semi-private and public spaces, and within each space and for residents' observation opportunities. 


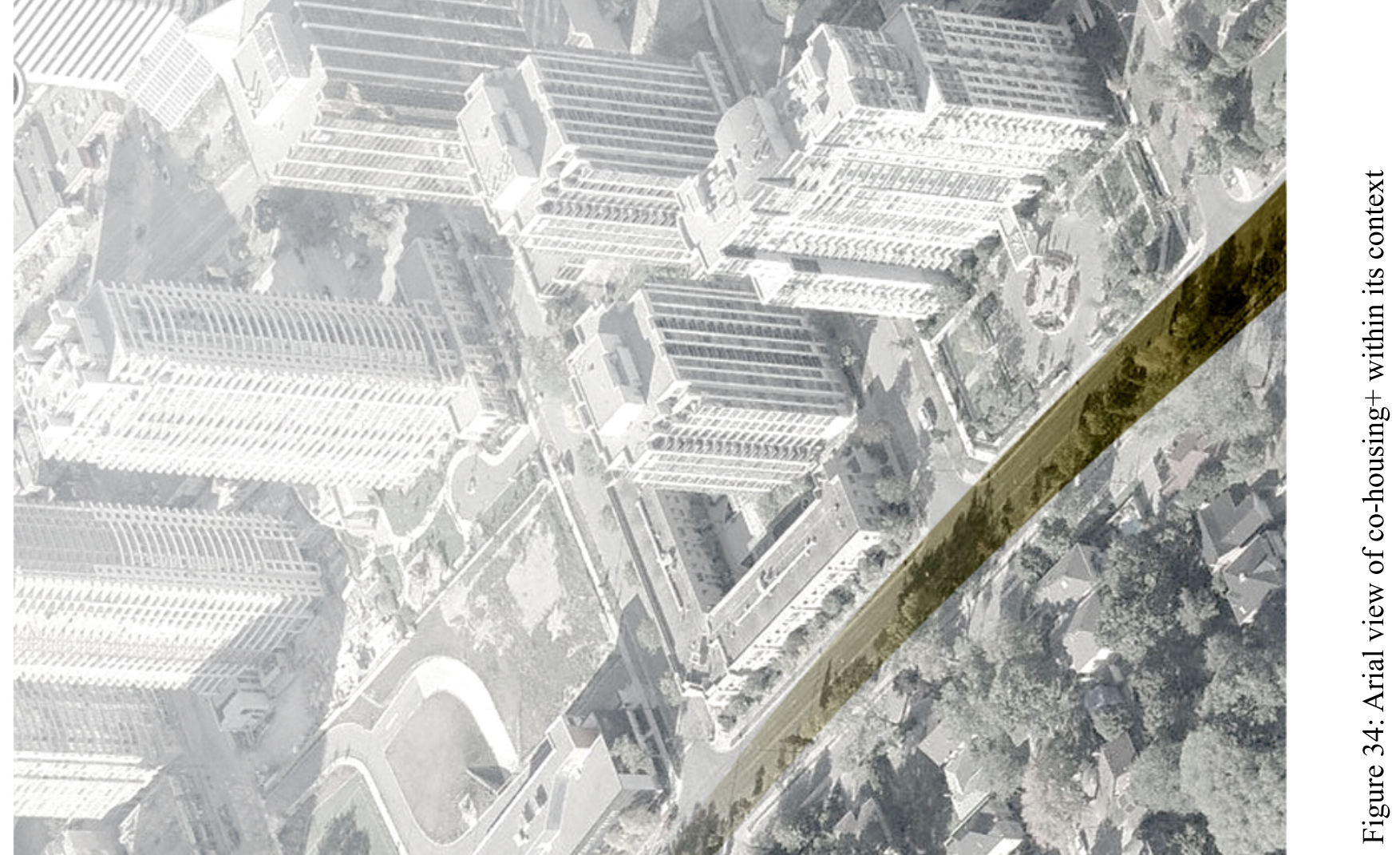

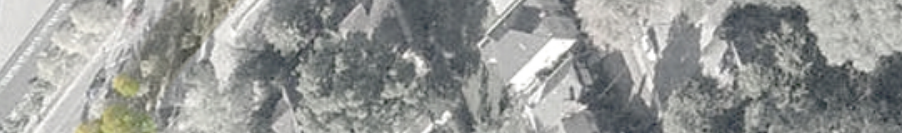

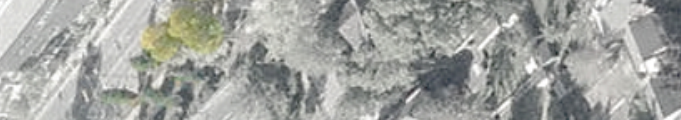
(2) 2.1. 1. $1 \mid$
3

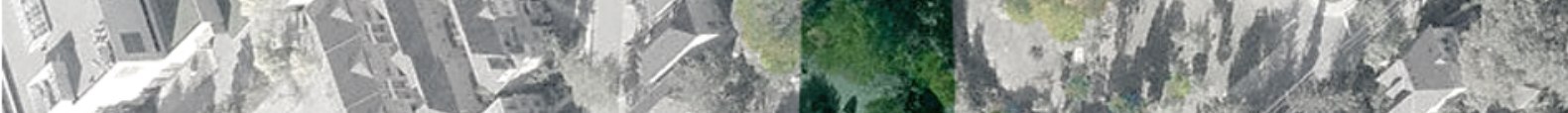
1.12
1

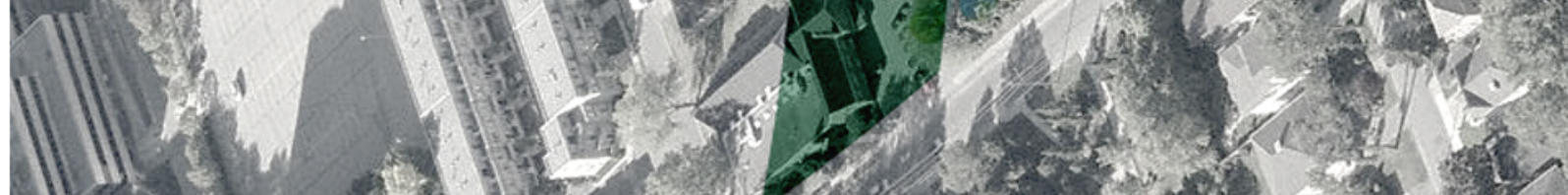
III, of 


\section{Towards a Greater Community}

The public spaces are located at the ground level and can be accessed from the main street or from the park (Figure 35). The main architectural element of the design is the public courtyard which consists of two parts: a large internal courtyard as the central element of the design where the park greenery is extended in the community, and a small external courtyard where the community is expanded to the greater surrounding neighborhood (Figure 36). The scale of the building and the materiality of the façade, stone and wood, respond to the adjoining skyline and the surrounding park (Figure 37). The building comes to existence within the park extending the open public space to an enclosed community environment. The accessibility and availability of these spaces for outside visitors is based on community rules and regulations defined by the residents. For example community decides to provide membership to approved neighbors in order to give public access cards to these spaces such as the gym and the study room or set the accessibility time for public spaces from 9 am to $5 \mathrm{pm}$. Instituting certain rules

brings the benefits of economical support and high level of control for the community since it is maintained and operated by its residents. 
Figure 35: Building form top view showing the access points

Figure 36: Building form axonometric view showing the notion of the park greenery extended in to the courtyard + the courtyard extended out to the park
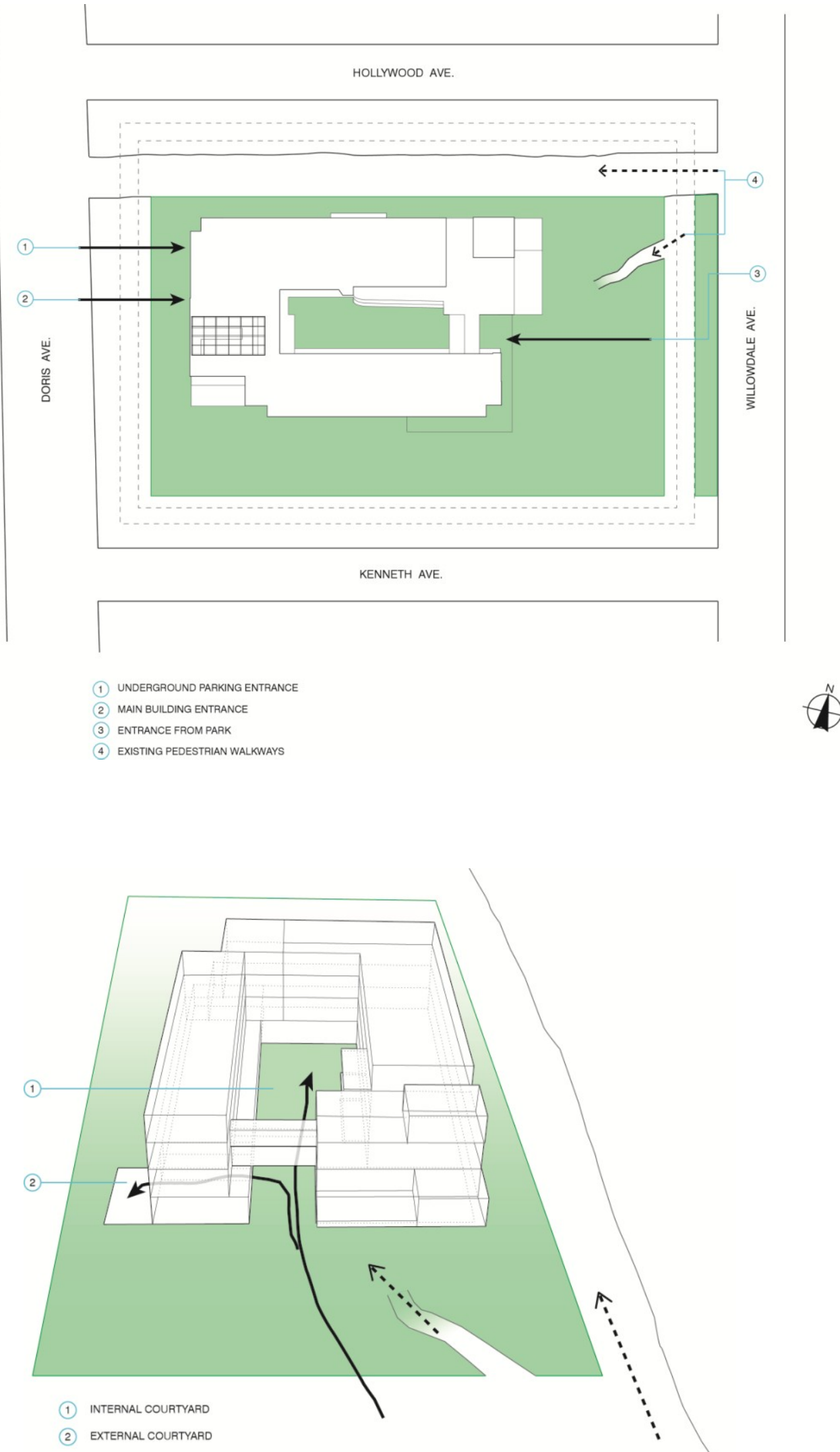
0
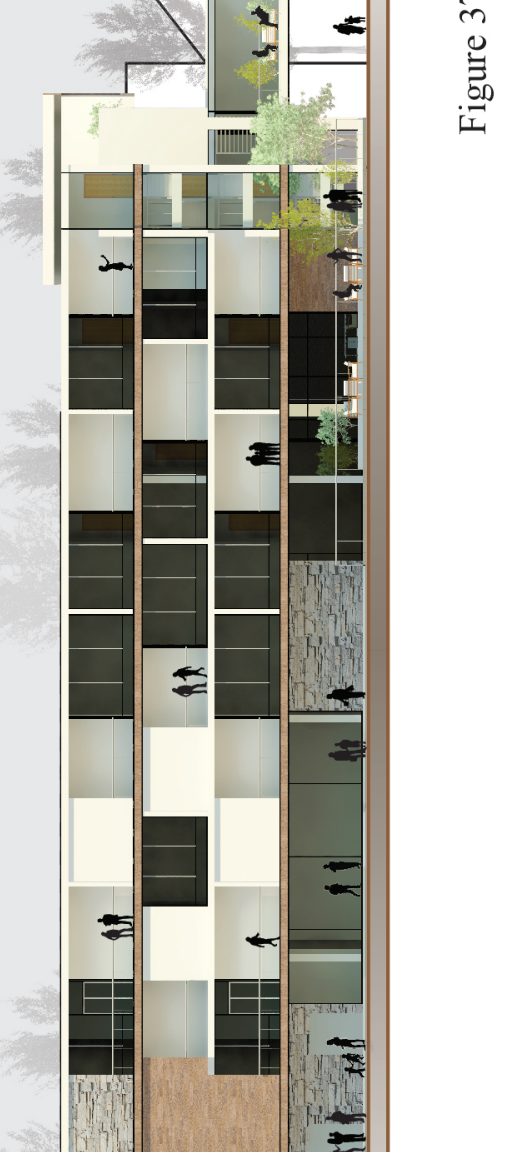

i. एँ

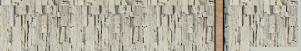

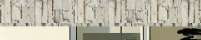

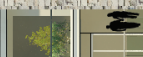

$1 \times$

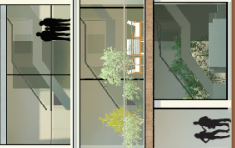

풀

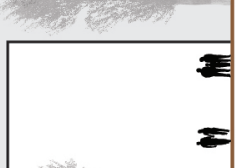

$-4 x^{2}$

matsents

$$
\text { anden }
$$


Figure 38 illustrates the layout of the public spaces at the ground level:

1) café and exercise room

2) greet space, library, study space, workshop space, lounge, multi-purpose gallery space, and theater room

Although all these spaces can be accessed by the public with regards to community regulations, the presence and the control of community members creates a secure environment. Nevertheless it should be noted that there is always a concern about opening up to public and security since to some degree a residential type becomes less safe when a more public space is added in.

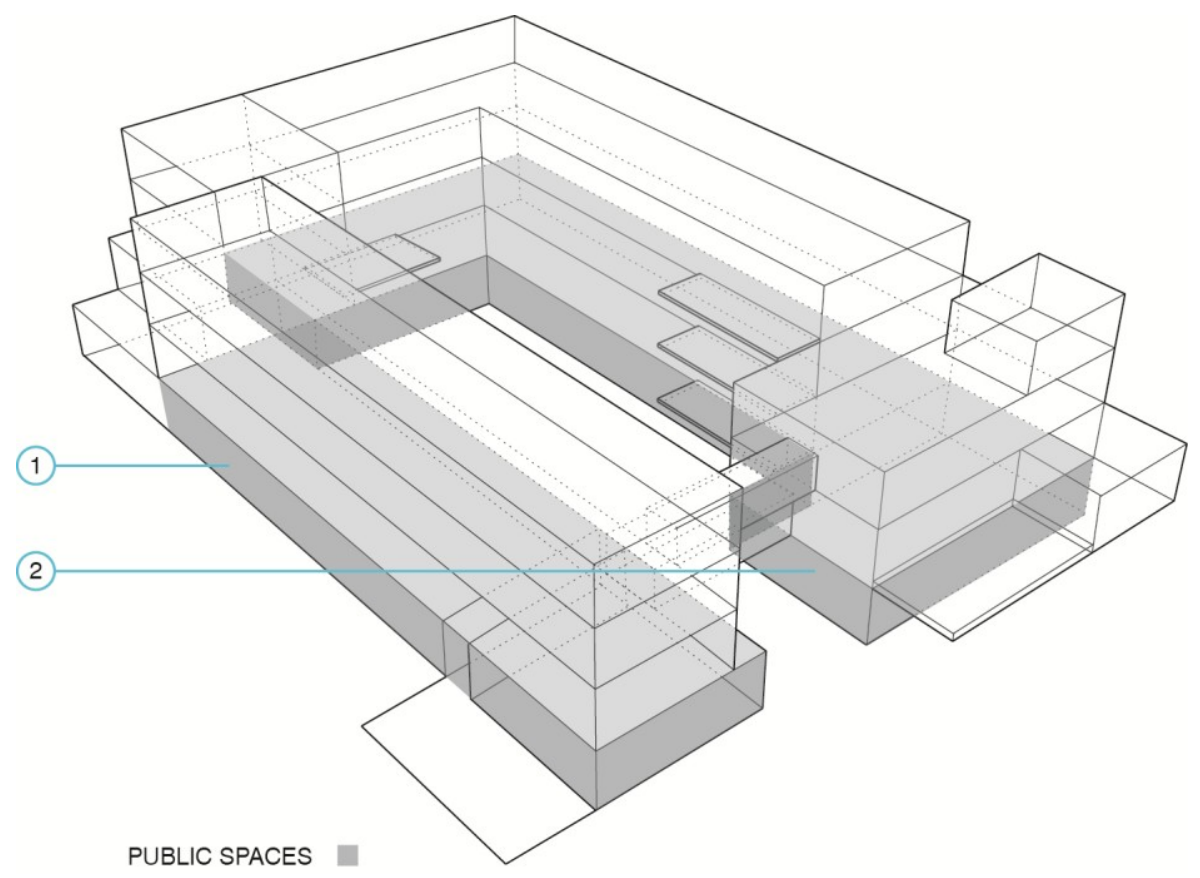

Figure 38: Schematic design demonstrating the layout of the public spaces at the ground level 


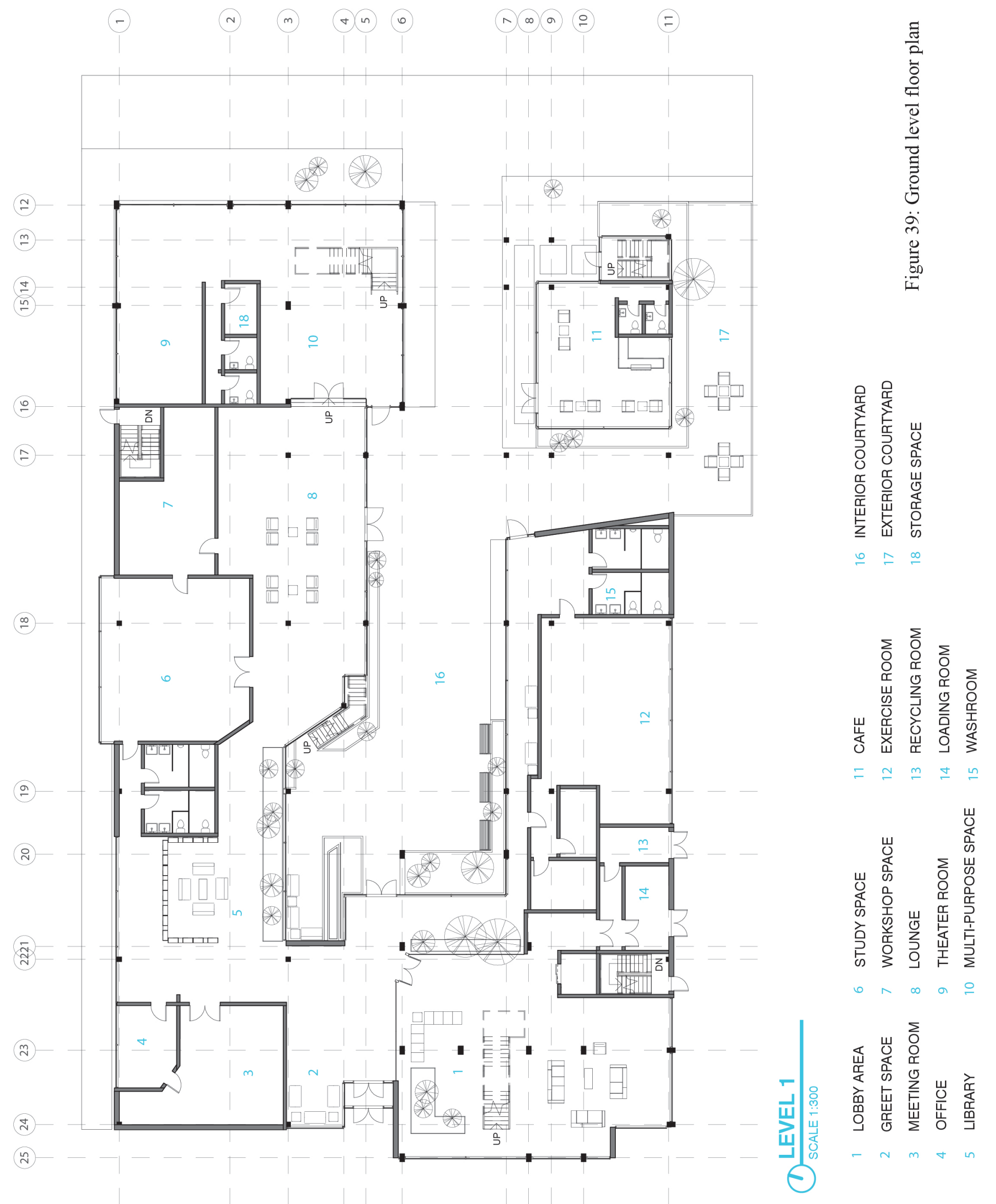


The ground floor proposes variety of programs in order to attract the local neighborhood to use the diverse available spaces and interact with others as well as to participate in the community events and activities. The design is intended to provide an inviting environment for social interactions for surrounding people to join the community and to benefit from what the community offers, hence creating a larger community. These group activities can be collaboratively planned by residents and public members such as weekly book reading, celebrations, educational workshops, general informative meetings. A small open library with a sitting area is designed in the main circulation path by which residents and public exchange books. Neighbors and community visitors can enjoy the café. The main courtyard is a pleasant and inviting place during warmer weather time for outdoor activities and social gatherings and is open in the direction of the park with some parts covered by the floor above. The courtyard is expanded around the secluded café to create an external sitting area. Supporting, exchanging, and interacting are extended beyond the Co-housing+ community with the involvement of public with community residents. After all, retrofitting an urban cohousing community to an existing neighborhood purposely promote the sense of belonging to a supportive and interactive community. 


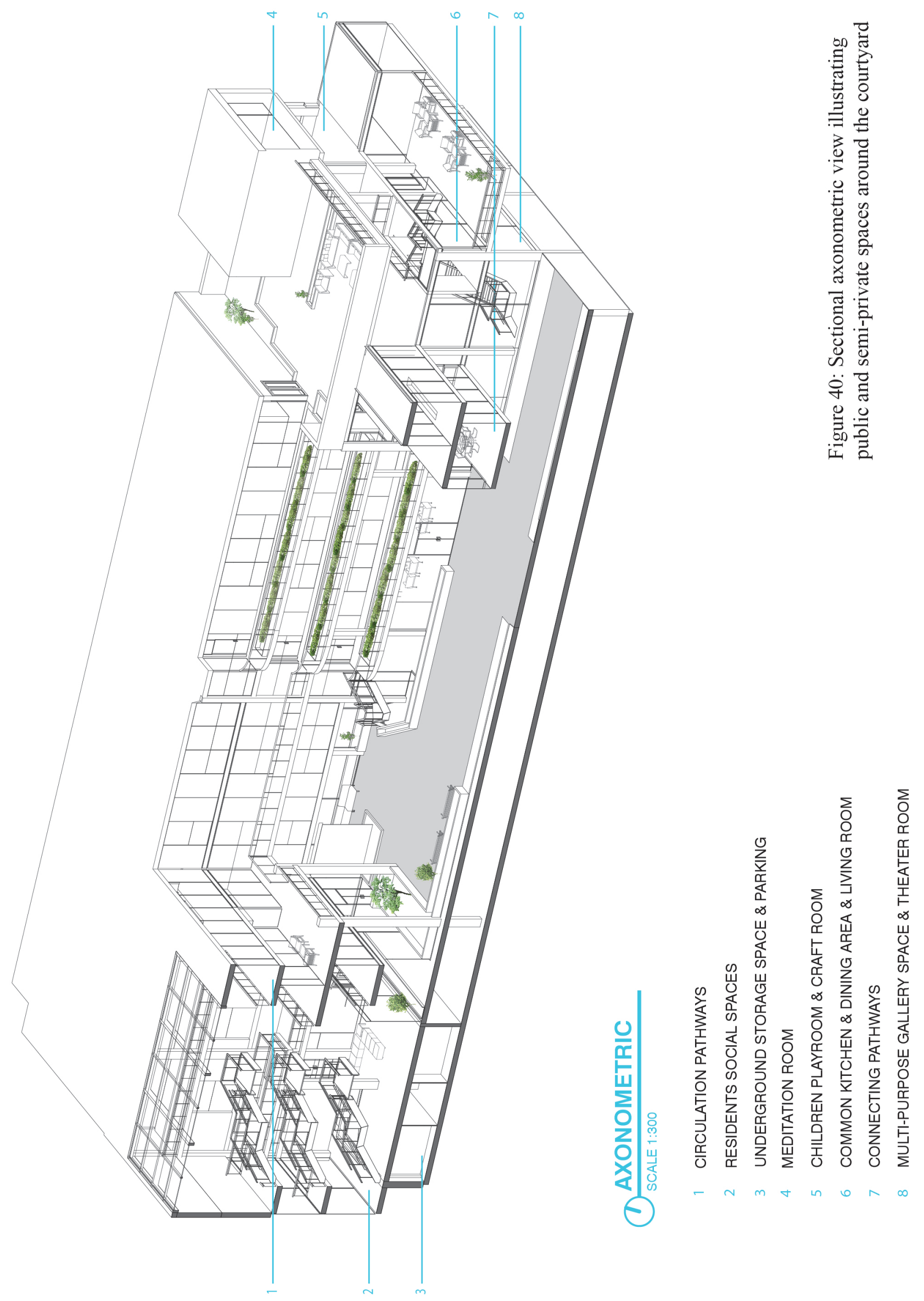




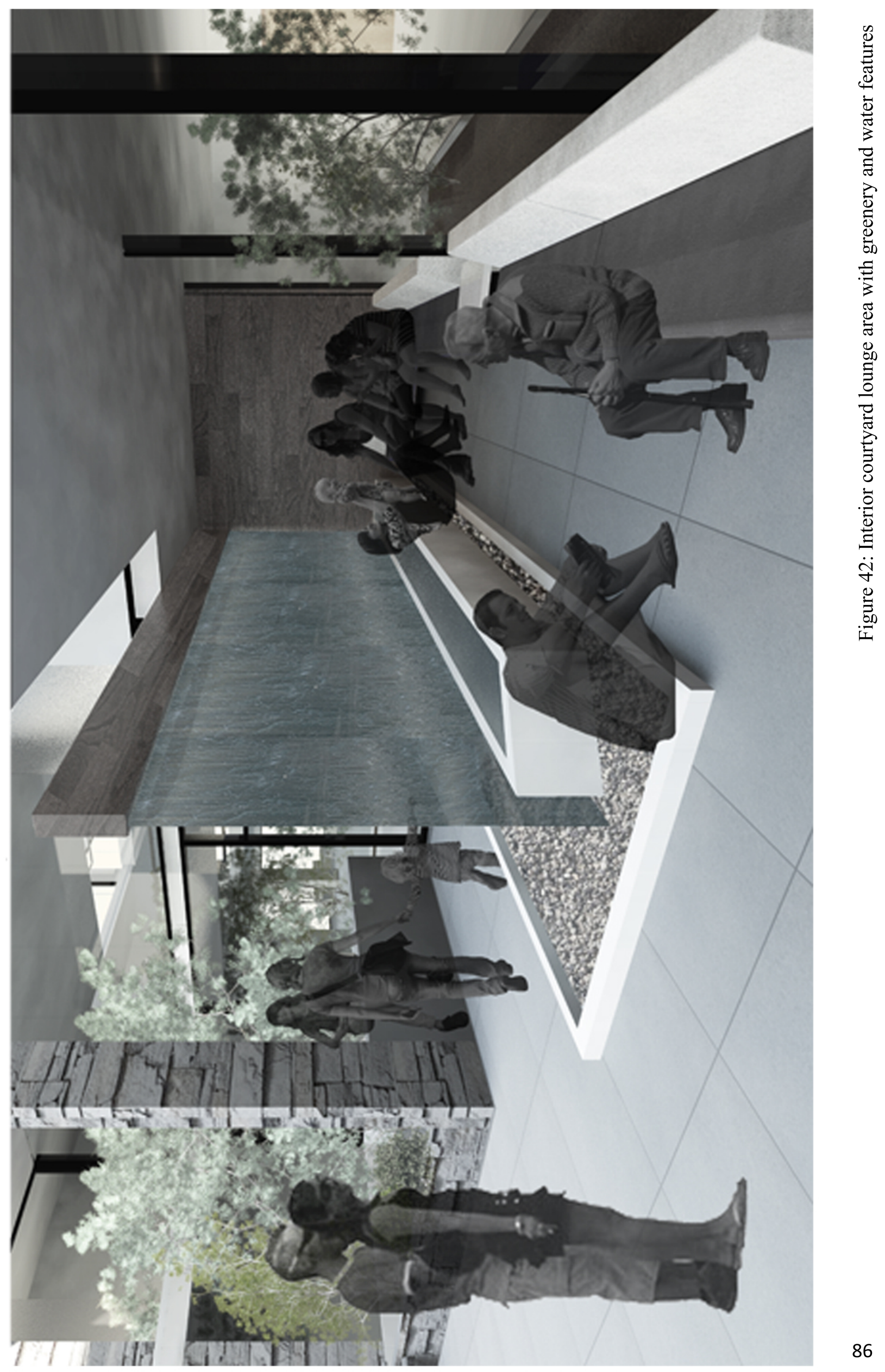




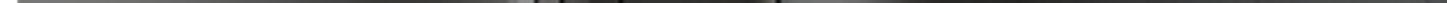

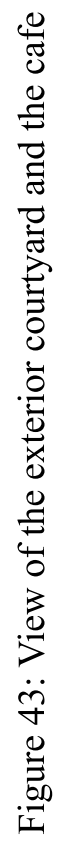




\section{Inner Collective Space}

From the first level to the second level the spatial type changes to semi-private and private zone. All the semi-private spaces are located within residents' main circulation path. The shared connecting pathways provide physical connection between public spaces, semi-private amenities and private dwellings as well as visual connection to semi-private and public spaces. The design integrates extensive green spaces at the ground level including the interior gardens and the exterior courtyard greenery. At the upper three levels residents share exterior patios. From the second floor up to the rooftop, these exterior patios and sitting areas offer great spaces for outdoor social interactions, adding green spaces to the environment. Patios are spread out within the semi-private spaces and circulation pathways. Furthermore, a three-level vegetation garden, as a vertical garden, in this compact location creates a natural environment for the community to collaboratively produce summer and winter vegetables, herbs, and fruits. The arrangement of the green spaces and gardens allows different types of residents' interactions with the greenery.

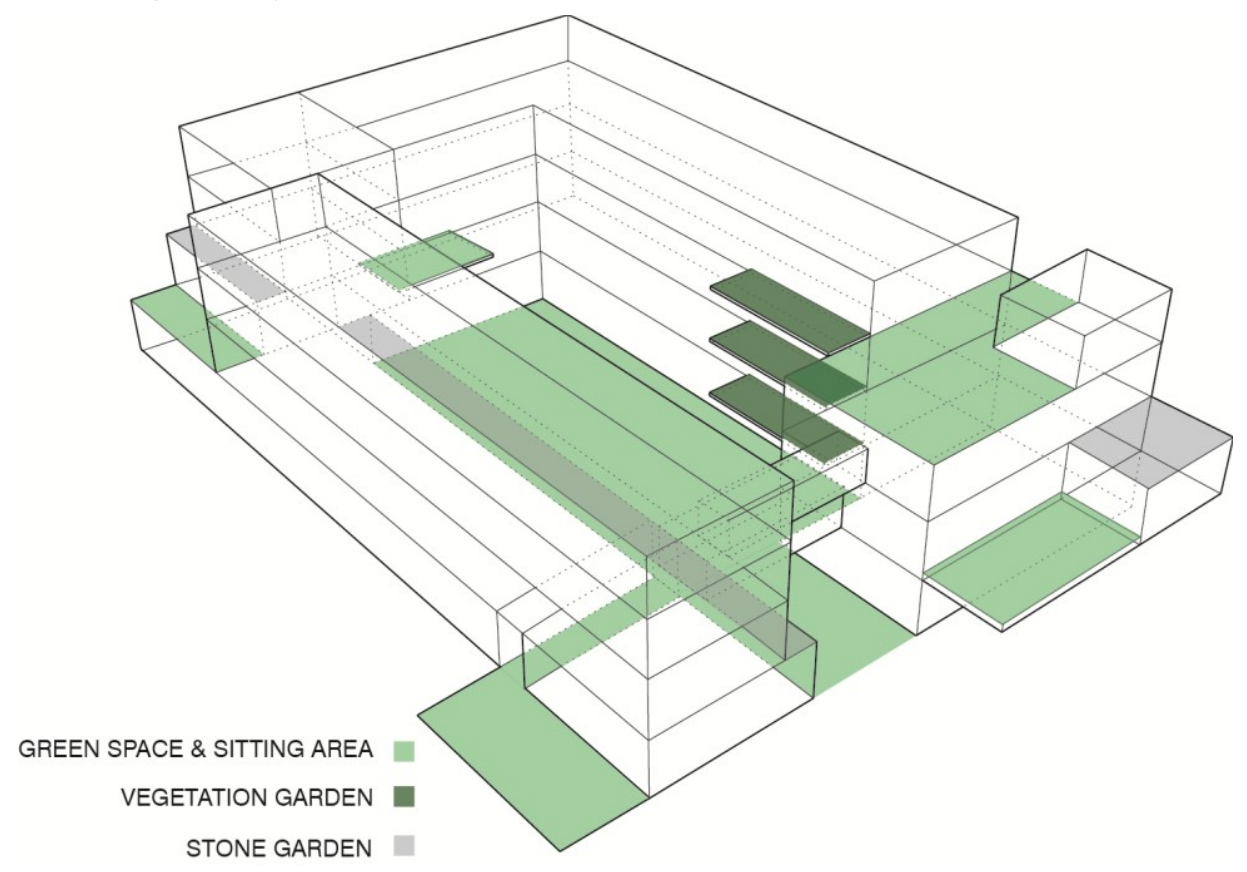

Figure 44: Schematic design demonstrating the arrangement of green spaces within the 
As it is illustrated in Figure 45, these semi-private spaces are:

1) residents lobby area at the first floor, social spaces varying in size and design at the second, third, and fourth floors. The design features an atrium where vertical circulation passes through interior social spaces benefiting from natural sun light and ventilation, which results in a pleasant environment for social gatherings. The guest unit is located at the fourth level of this block and is available for temporary residency based on the community regulations.

2) common dining area, kitchen, living room at the second floor, children playroom, children craft room, a lounge at the third floor, and rooftop sitting area and meditation room at the fourth floor.

3) connecting pathways that physically connect the second common block to the residential apartments. On the south side of the building complex are located the extension of the interior horizontal movement paths.

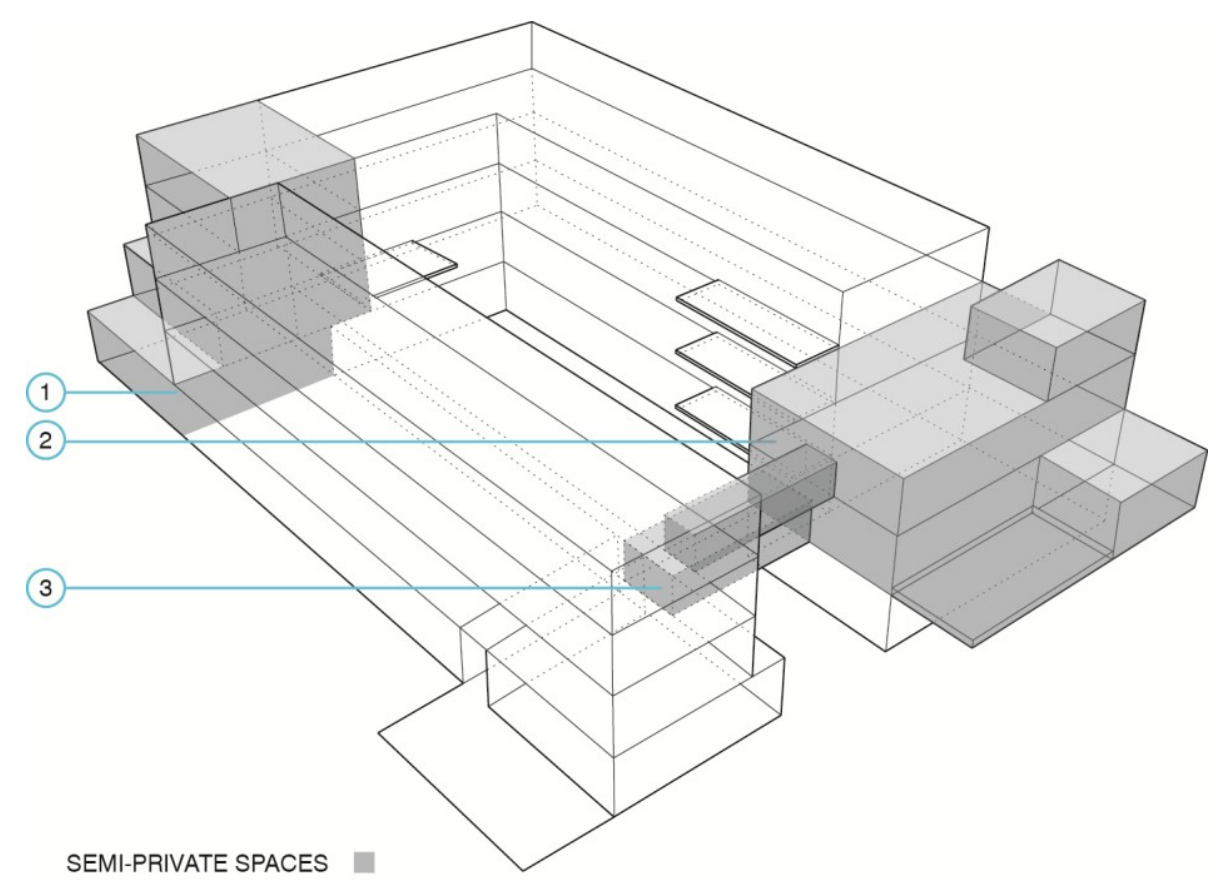

Figure 45: Schematic design demonstrating the layout of the semi-private spaces 


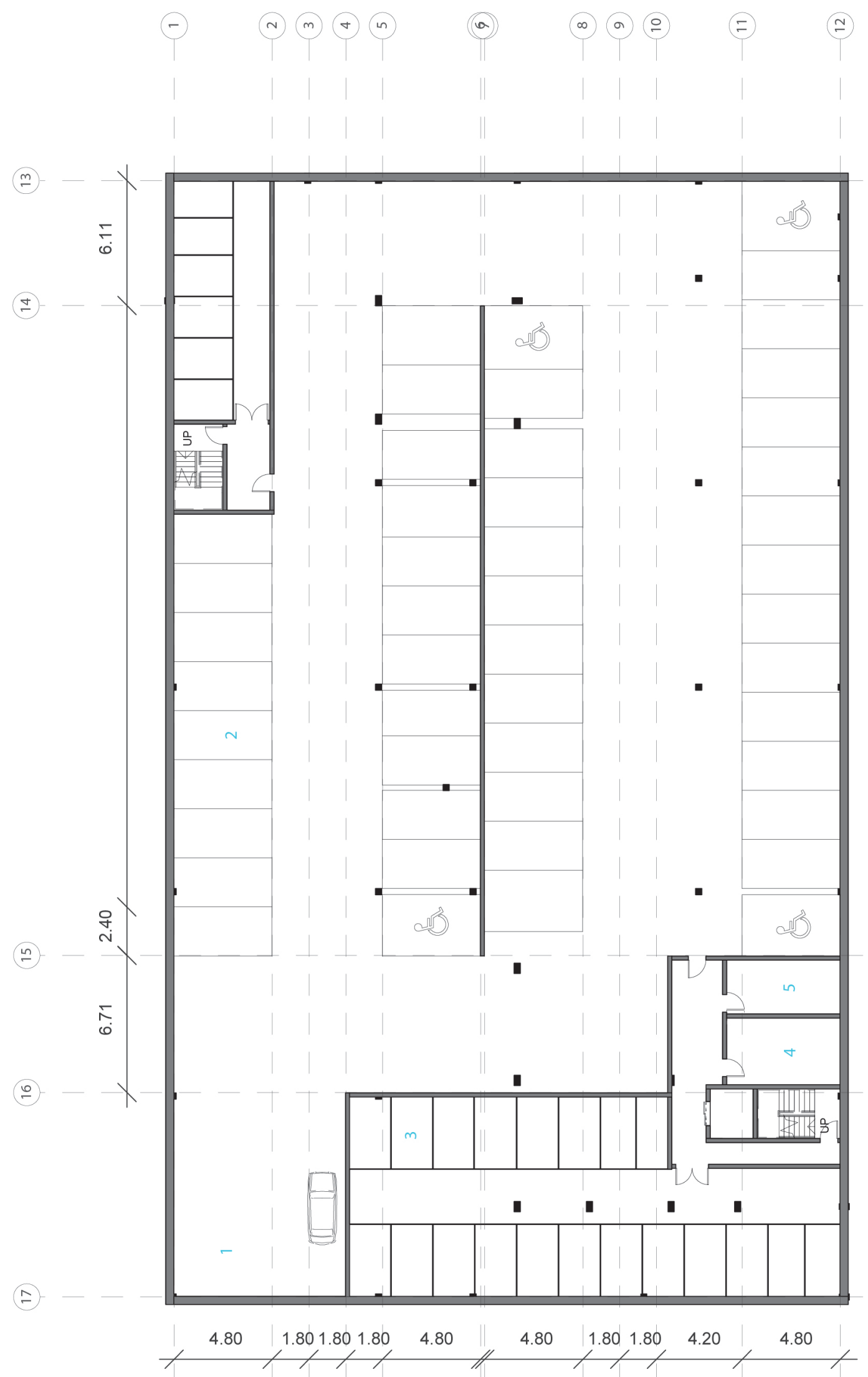

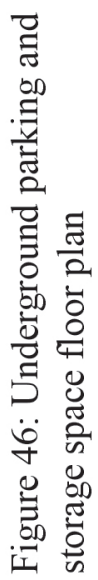
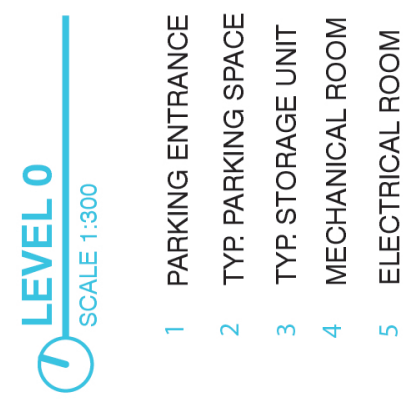


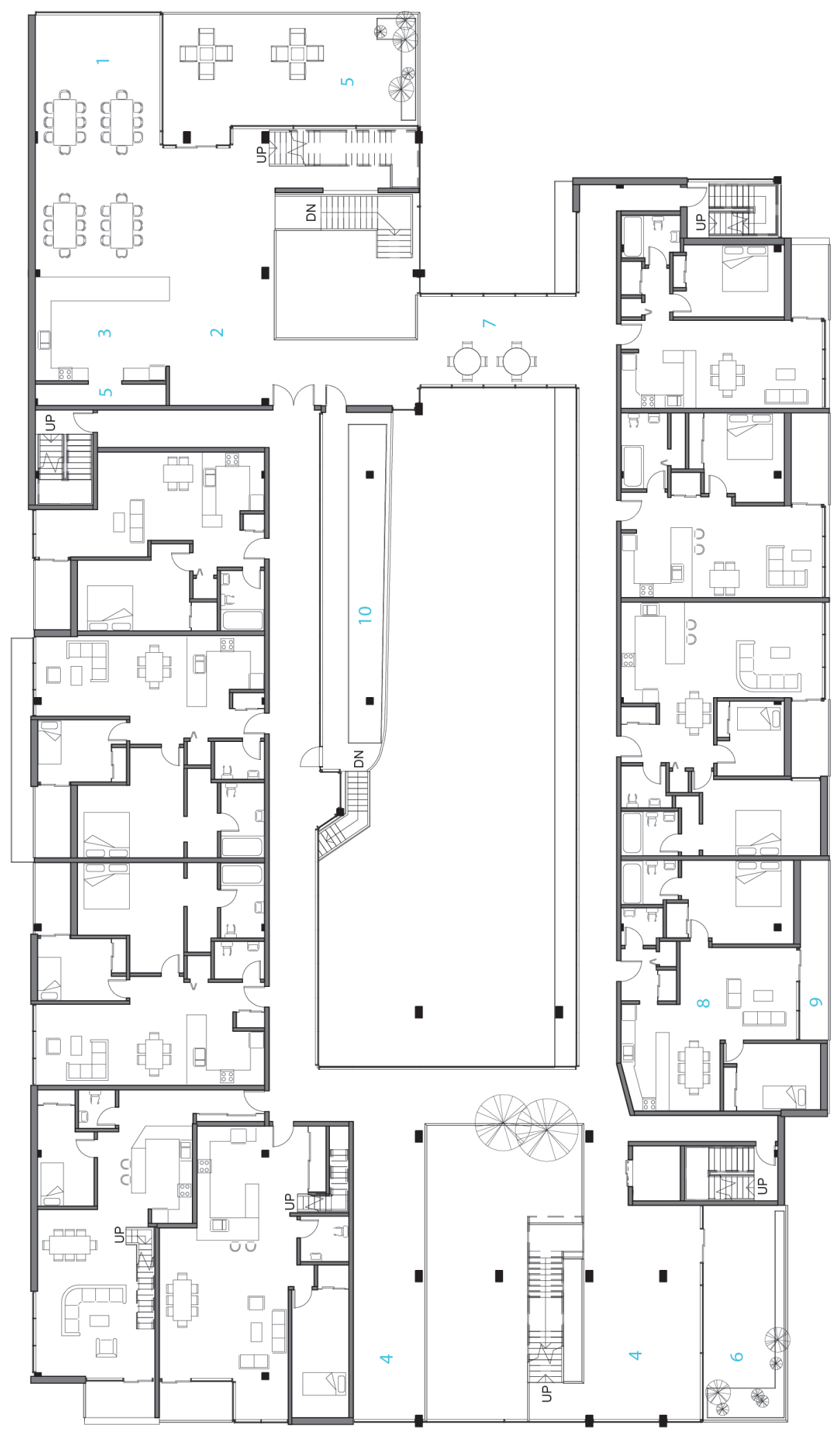

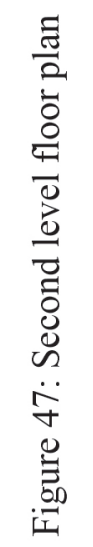

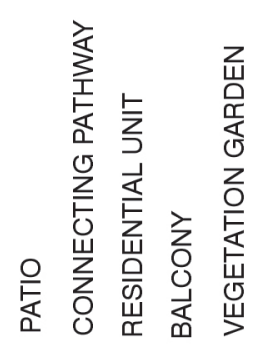




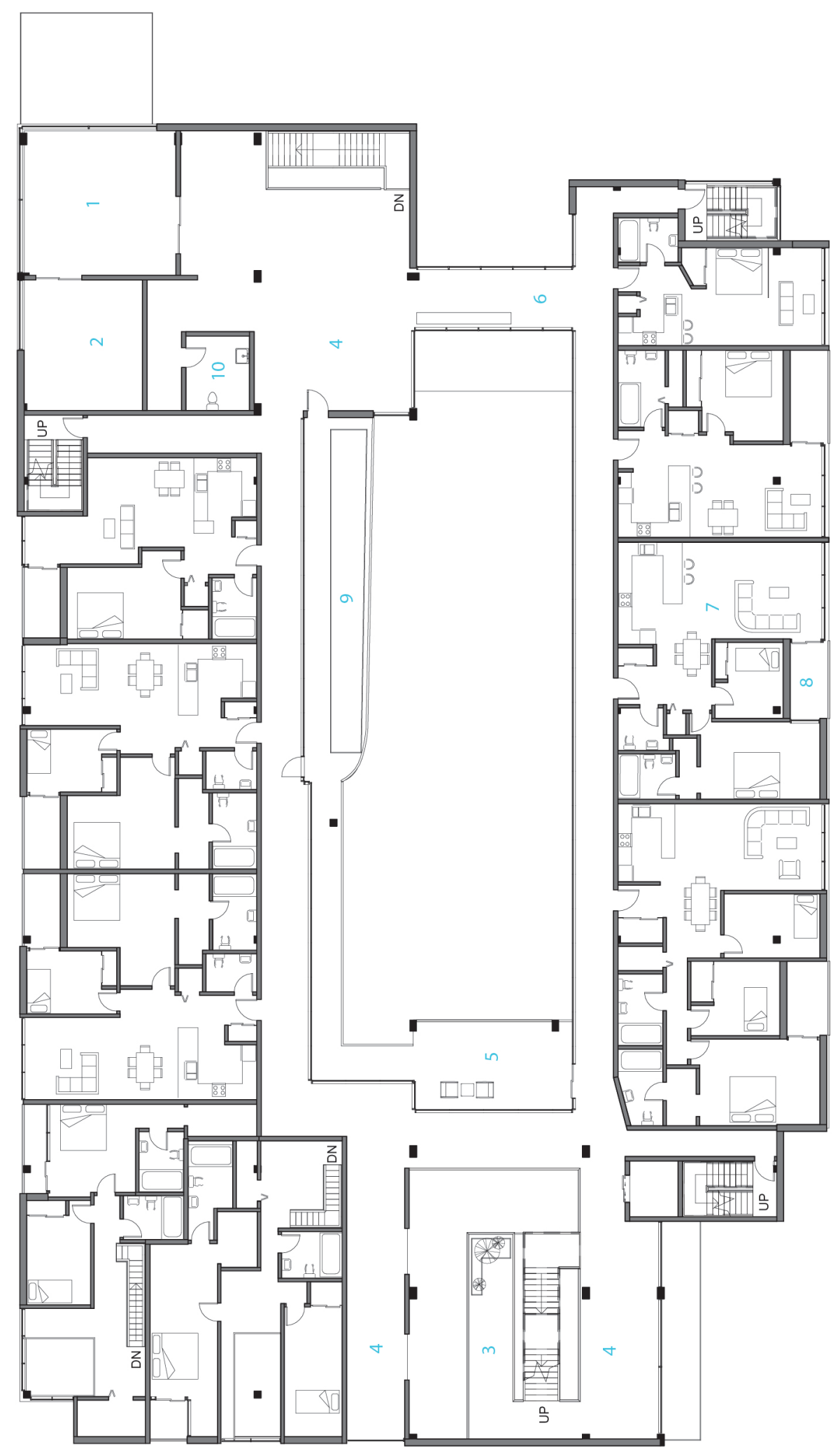

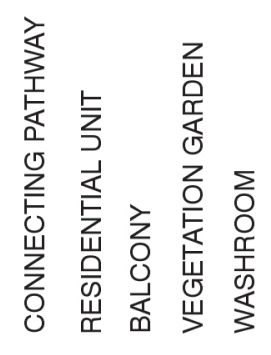

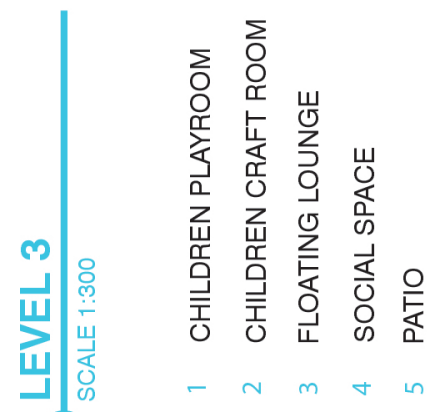




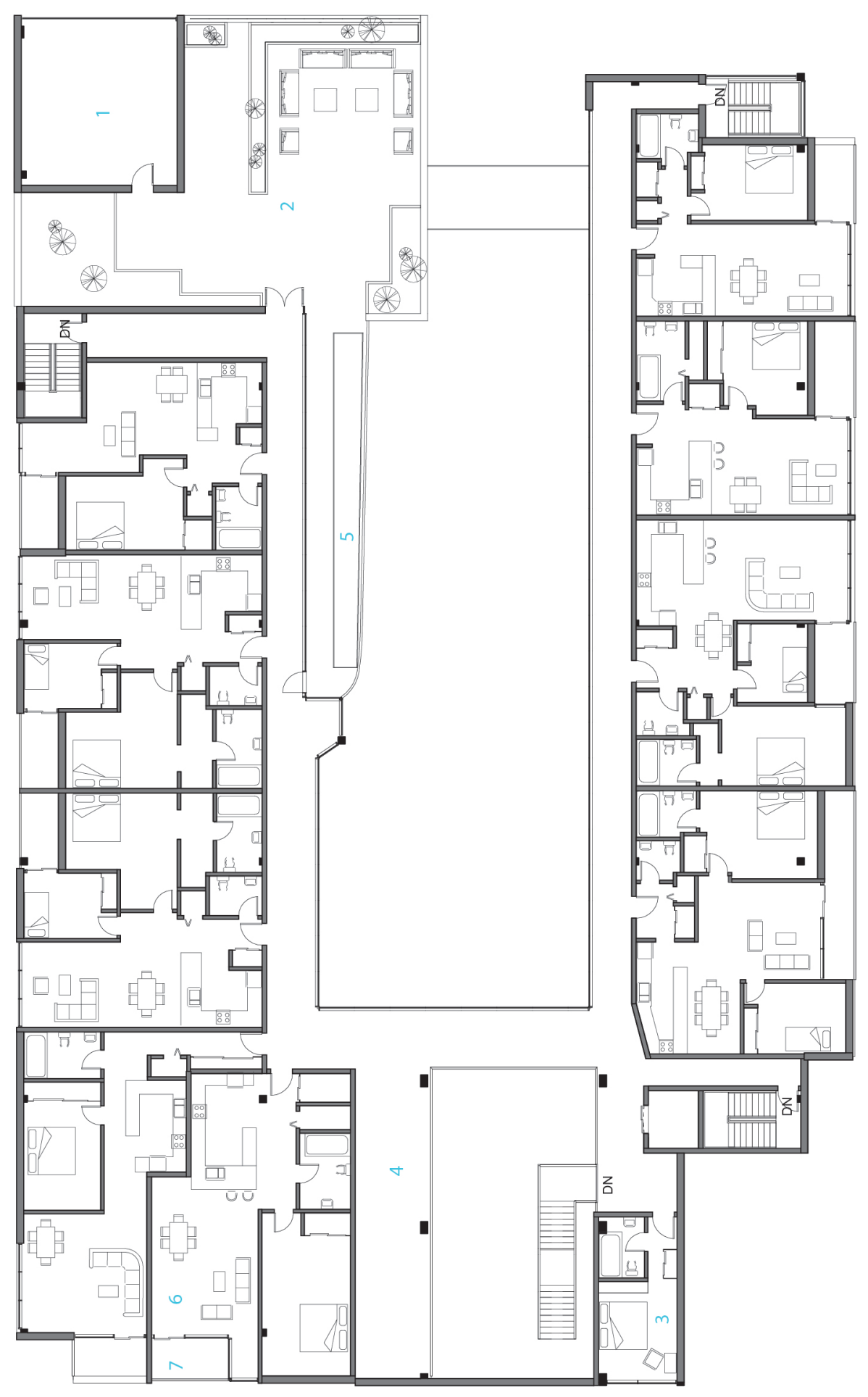

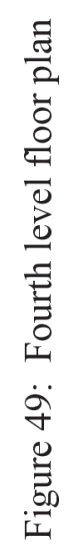

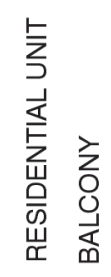

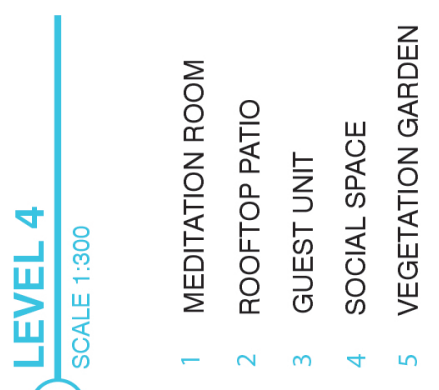


The social spaces, shared facilities, and private dwellings are contained by the main circulation paths and connecting walkways with the intention of increasing the chance of meeting and social interactions among community residents or between residents and visiting public members. The layout of lounges, sitting areas, and open social spaces are intentionally designed so that residents could deploy and alter them to suit the type of planned event or activity. They actually provide opportunities for multiple events to take place at the same time within the community. Residents share activities of childcare, dining, cooking, group exercising, gardening, participation in meetings, etc. by means of indoor and outdoor collective amenities. 

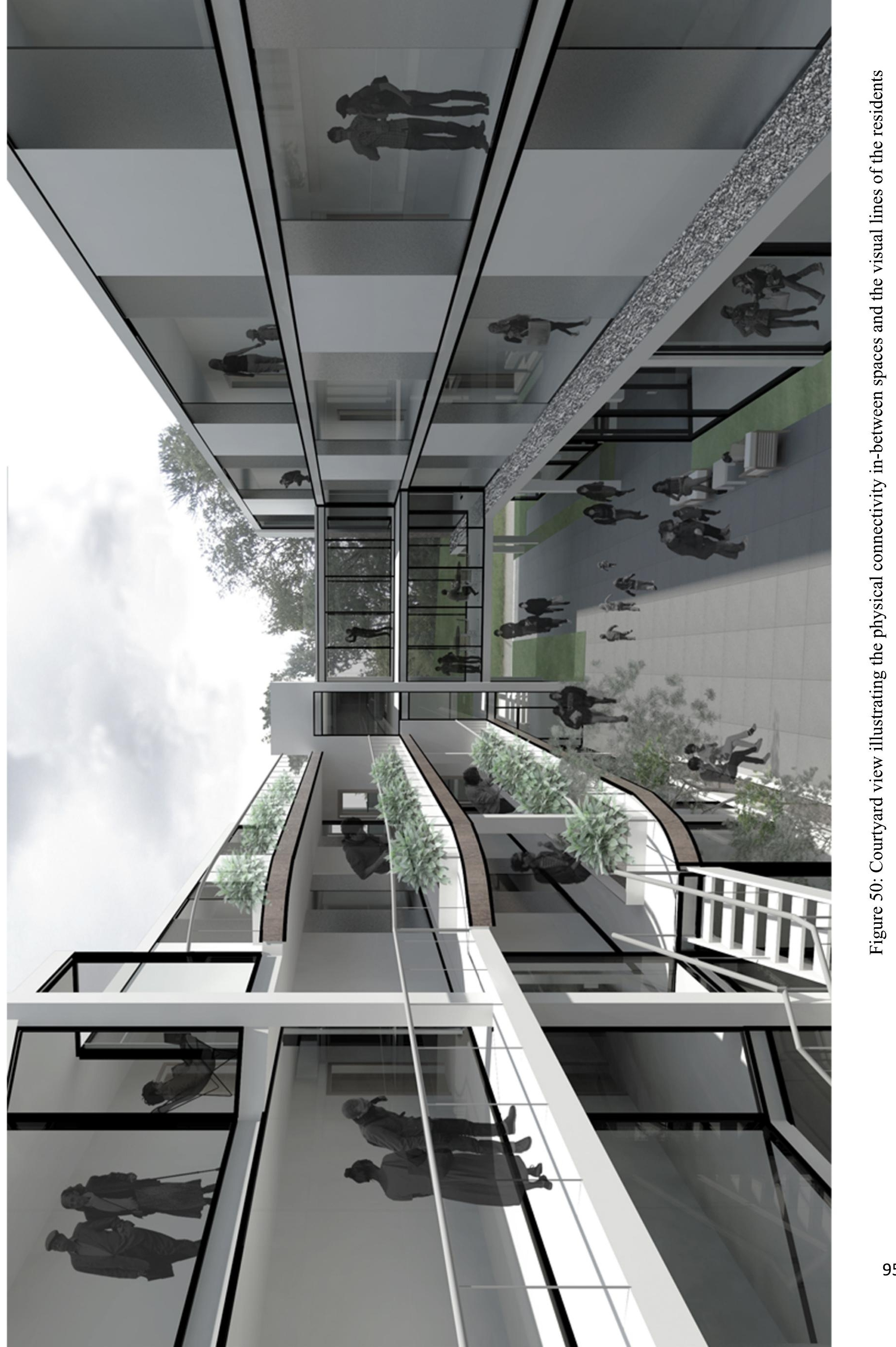


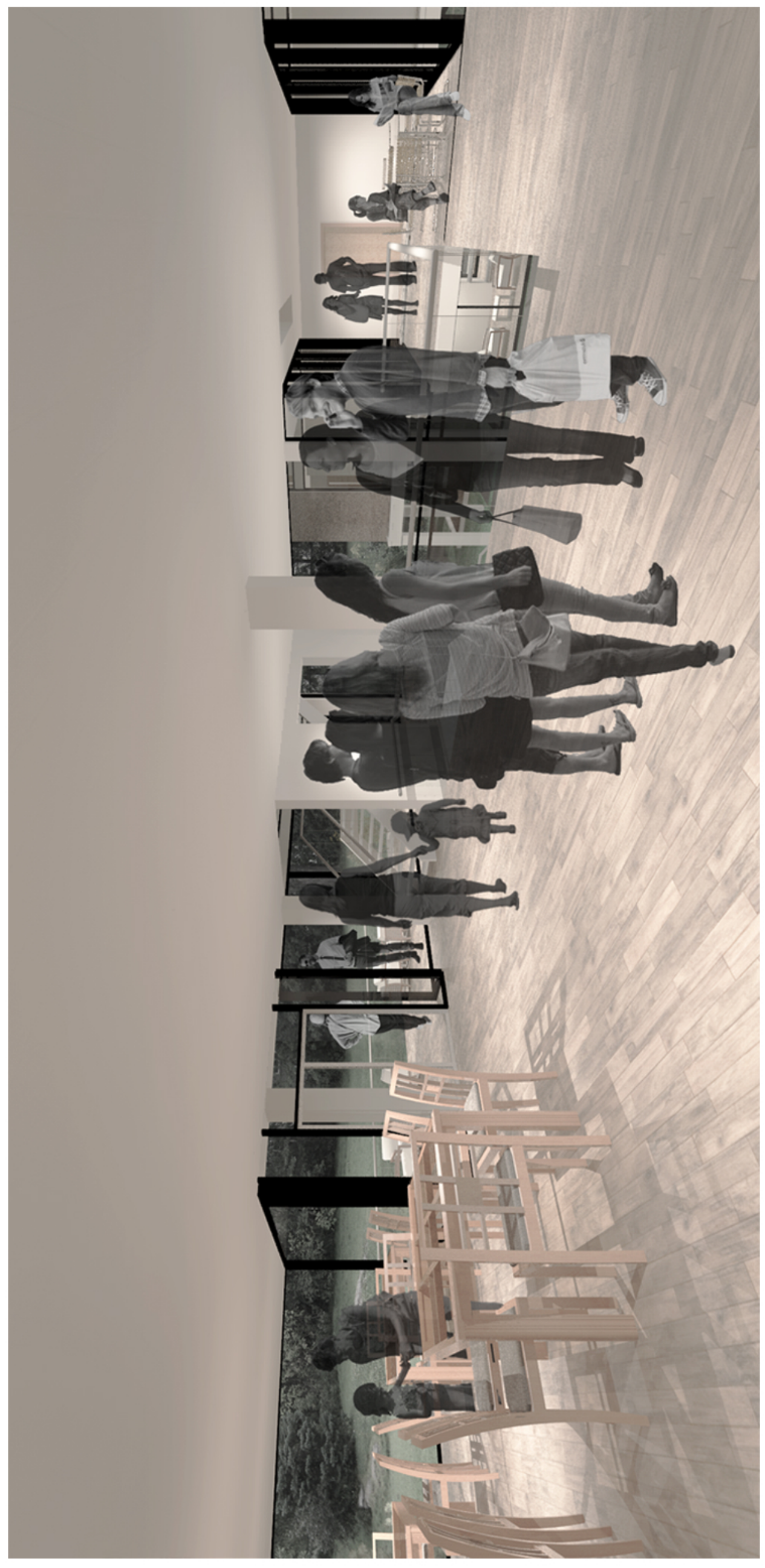

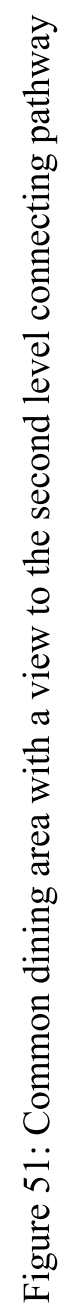




\section{Private Space}

The private space includes residential dwelling apartment units oriented towards the central courtyard. The circulation paths to the units' entrances are around the courtyard. Semiprivate spaces are arranged within each floor. The total number of 25 residential units are designed with regards to the case studies analyzed. As studies suggest, it is best suited for a cohousing community to integrate from 10 up to 40 households. This is for the reason that a smaller group makes the community become highly dependent on specific individuals or with larger occupancy the true sense of community is lost. ${ }^{121}$ The units in Co-housing+ differ in size, variation, and type of studio, one bedroom, two bedroom, and three bedroom. The design of each unit includes bedroom/s, a den space, a living room, a dining area, a kitchen, bathroom/s, and a small scale private balcony. Figure 52 shows the dwelling units located in the second, third, and fourth floors:

1) 12 dwelling units of one, two, and three bedroom (duplex)

2) 13 dwelling units of studio, one, two, and three bedroom

${ }^{121}$ Scotthanson, Scotthanson, The Cohousing Handbook: Building a Palace for Community, 3 


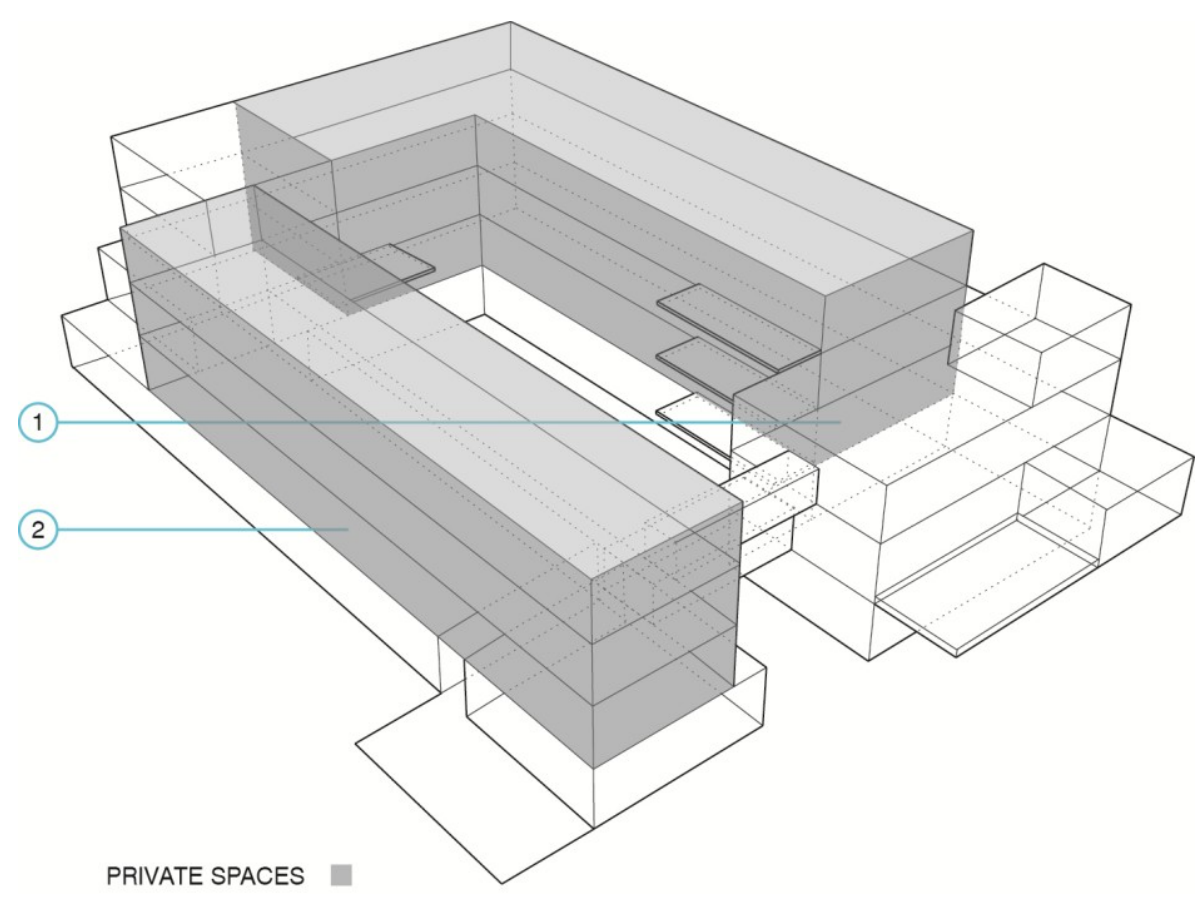

Figure 52: Schematic design demonstrating the layout of the private spaces

With regards to CMHC report in 2013, the rental market, both primary and secondary, in GTA area generally shows a very high demand for rental accommodation. ${ }^{122}$ With a higher rental rate of $3.1 \%$ in both 2013 and 2014 , the city supply has increased in the secondary market and surpassed the demand. However, the report shows that despite the demand and supply increase, supply growth has a much slower rate especially in the North York region.

122 "Rental Market Report-Greater Toronto Area" https:/www03.cmhc-schl.gc.ca/catalog/productDetail.cfm?lang=en\&cat=79\&itm=37\&fr=1413397668416

* Primary rental market includes self-contained units in a building with the purpose to house rental tenants.

Secondary rental market encompasses self-contained units that are available for rent including condominiums and houses. (definitions by CMHC) 
Considering that renting is not common in the cohousing model, there is actually a lack of rental units in existing cohousing projects, which results in fewer opportunities to experience community life and thus it likely limits the recognition of this model within mainstream society. ${ }^{123}$ The outside public is not able to observe the cohousing benefits when there is a lack of rental units and/or the community's shared facilities are not open to the public. Williams, the author of "Predicting an American Future for Cohousing", affirms that research shows the increase in adoption rate where rental accommodation exists, and moreover when the community has stronger social ties with neighbors. ${ }^{124}$

In the proposed design, the issue of the low supply of rental housing is taken into account by adding rental units. These units, total of 5, are offered at the market price and the affordable price through specific covenants and are kept and maintained by the community. This inclusion of rental units has two main purposes: firstly, to provide the opportunity to experience 'living together' lifestyle in a community for low/high income people who are interested before they potentially become owners, and secondly, to address the high demand for rental accommodation in Toronto. Moreover, the rental units are proposed to be mixed in with other dwelling units in order to firstly create a friendly and accommodating environment for temporary residents and secondly maintain the security by allowing residents to control the transit community.

123 Williams, "Predicting an American Future for Cohousing", 280
124 Ibid., 280 

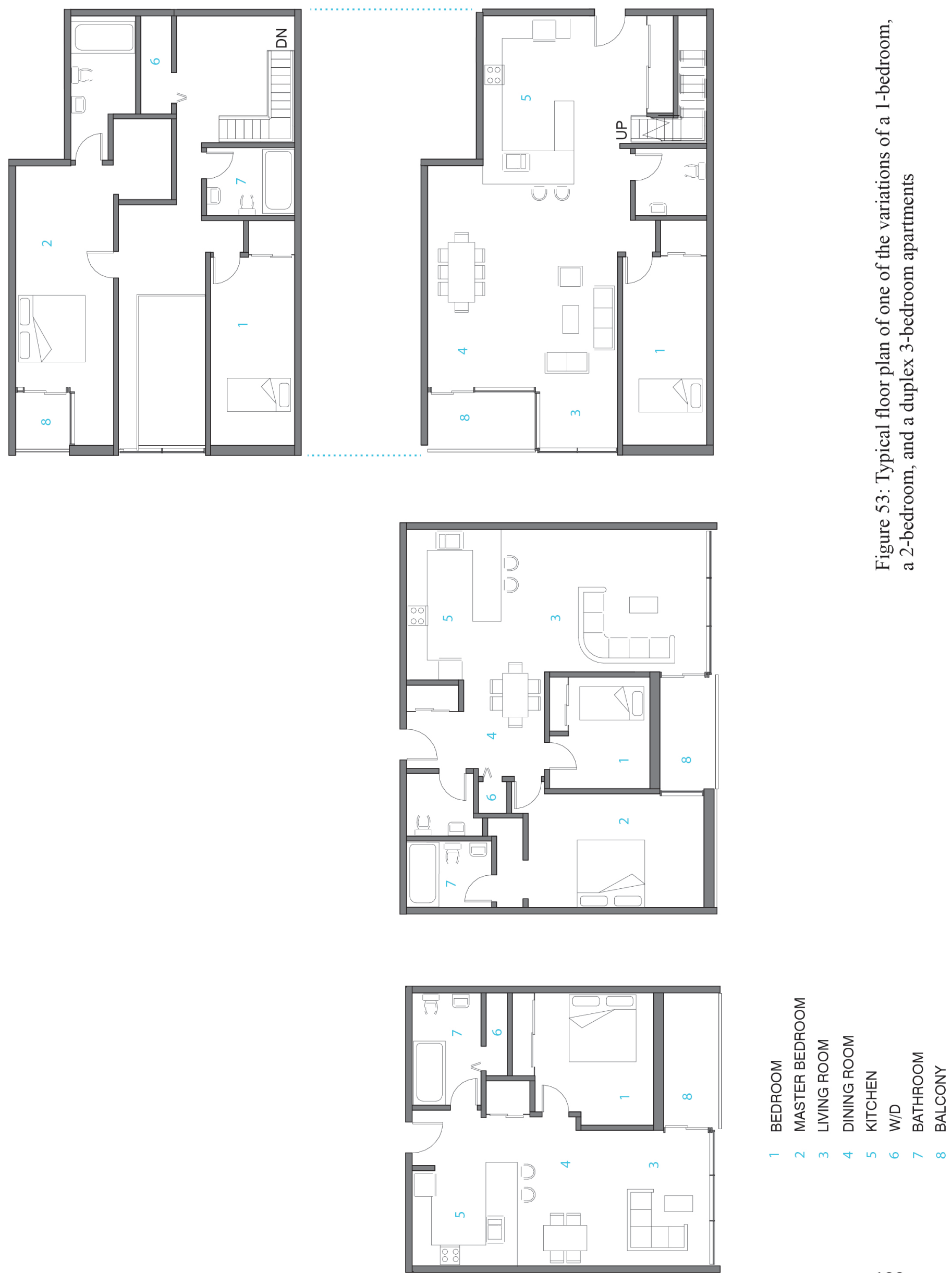


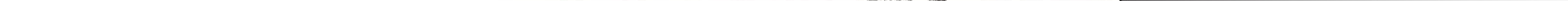



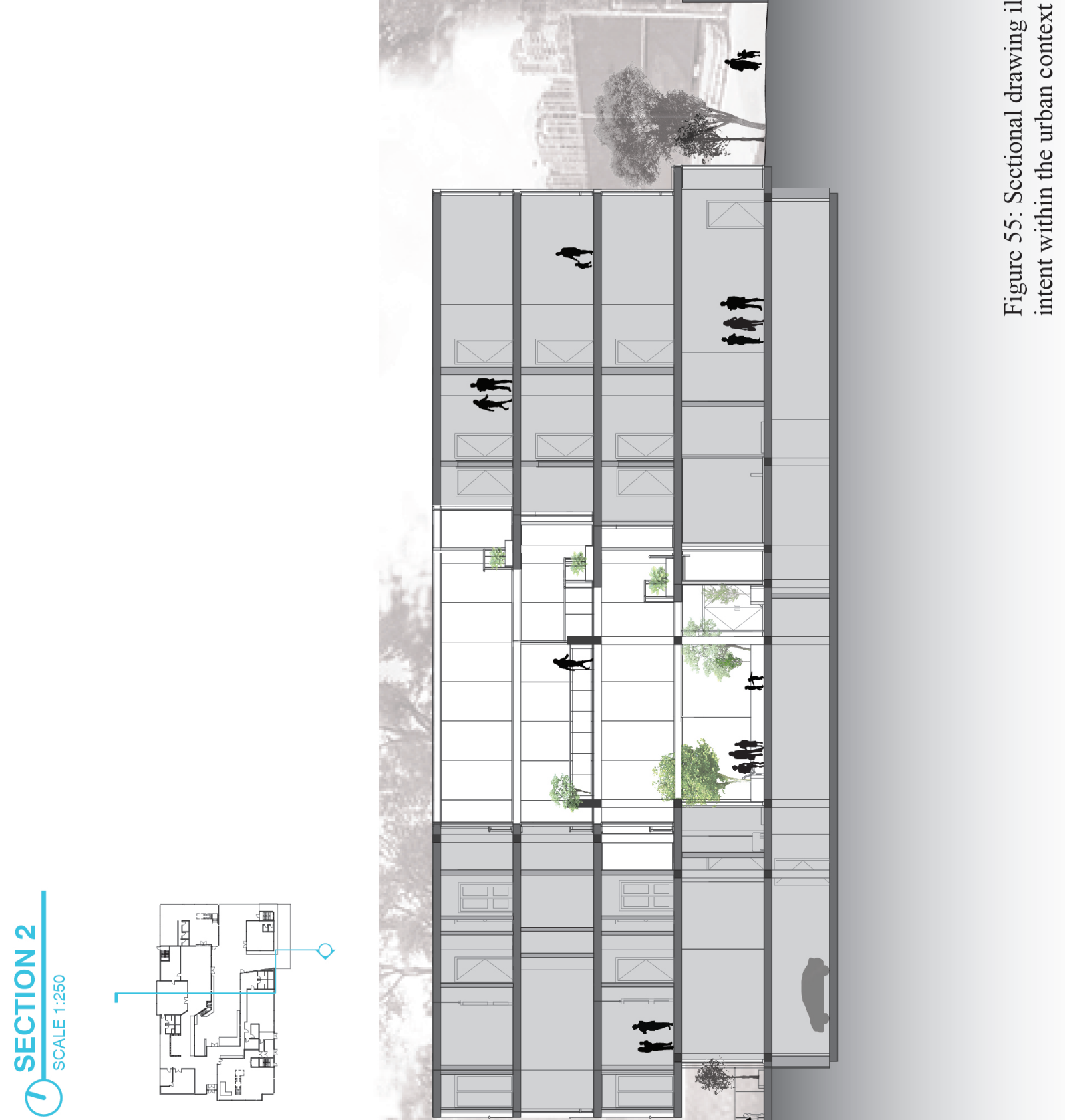


\section{Connectivity in-between Spaces}

As it was stated in the previous section, the buffer zones, as the transitional spaces, are designed and positioned to create community's observation views and also to provide opportunities for residents to meet and to interact. The layout of the main circulation pathway, interior or exterior, is around the central courtyard from the ground level up to the fourth level. This allows for the horizontal movement of the public at the first level and the private circulation of the community of residents at the remaining levels.

The private vertical movement occurs at the intersection of common building blocks: one stairs connect the residents' lobby area at the ground level up to the social spaces, the apartment units, and the guest room at the upper levels and the other stairs are located at the multi-purpose space at the ground level up to the upper levels. The rooftop lounge and mediation room are accessible only through the north side residential block, promoting residents to pass through the pathway around the building which again serves the intentional design for social interactions. Furthermore, the vegetation gardens are accessible at each level's horizontal circulation pathway from the interior, stairs from the courtyard to the second floor, and an exterior pathway from the third floor's patio. 


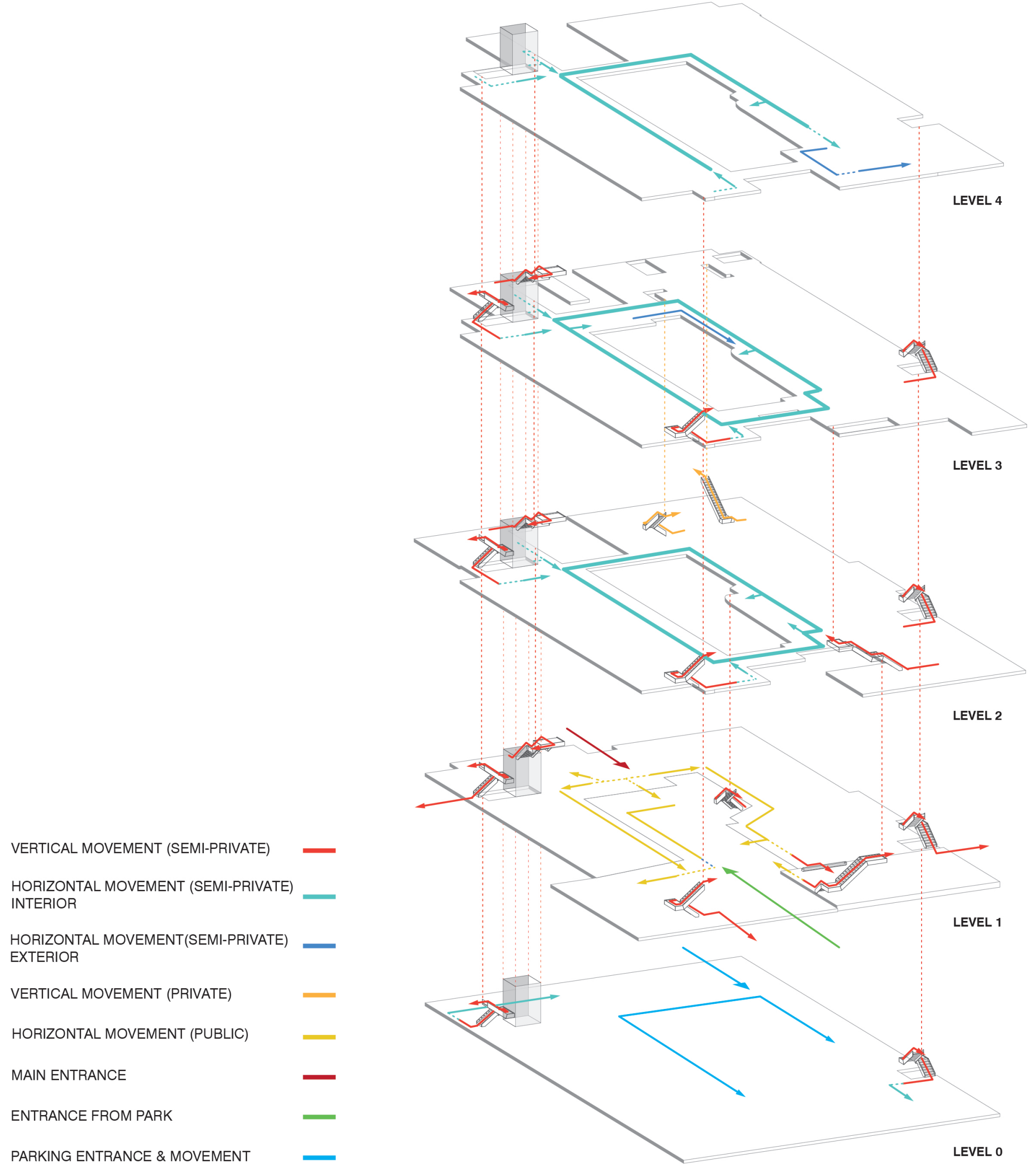

Figure 56: Circulation diagram showing pathways in public, semi-private, and private spaces 


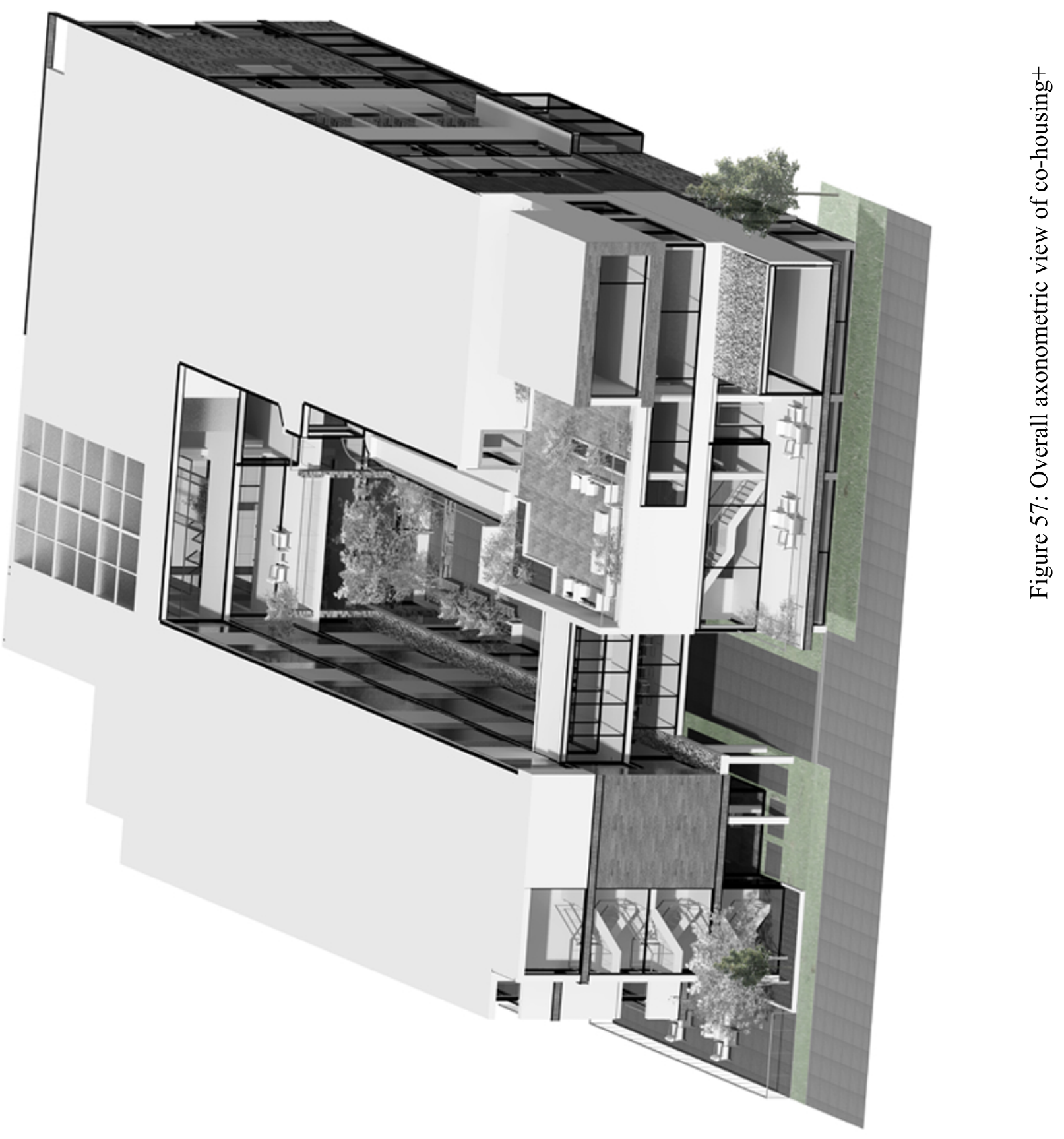




\section{The Sense of Privacy}

In Co-housing+, the buffer zones, verandas and pathways, provide opportunities for residents to have views to observe both public and semi-private spaces so that they can choose their level of interactions. The orientation and the position of the connection spaces along with the semi-private and public spaces, provide residents' surveillance views for safety and security prospects. The design of pathways provides opportunities for the community residents to cross paths on a daily basis maximizing social interactions whilst maintaining privacy.

Public spaces can be accessed by the neighborhood based on community regulations. The presence and the control of community members create a secure environment. Nevertheless, it should be noted that there is always a concern about opening up to public and security matters since to some degree a residential type becomes less safe when a more public space is added. In the proposed design, all the entrances to the building and from courtyard to interior space are secured. Semi-private spaces and private dwellings are arranged in a way that they are only accessible by residents. In public and semi-private spaces, the physical boundary of the connecting circulation pathways in the direction of the courtyard is glazed so that the movement encompasses transparency in order to create visual lines between spaces. The language of this boundary changes at the private level where the glazing is gradually concealed with the movement at every residential entrance in order to maintain residents' privacy: transparent to translucent to opaque. 


\section{The Sense of Belonging}

The design components of co-housing+ complex are arranged with the main intention of increasing social interactions among residents and providing opportunities for the public to take advantage of the benefits of the community life. This is a reciprocal relationship: to support, to cooperate, to share, to exchange, and to interact. Although residents and visitors have the mind set of community-oriented lifestyle and choose to blend in with a community because of its recognized benefits and supports, the role of design in fostering social interactions should be taken into account. In the proposed design, interior social spaces are intended to be utilized regularly by designing comparatively smaller dwelling units. The private balconies are also very small to encourage residents to use the exterior patios. All that said, what makes this community successful and sustainable, socially, environmentally, and economically, is the consequence of common values, the multi-cultural quality of the residents, and the diverse multi-generational residents, along with social on-site shared amenities like the daycare centre, the social spaces, the large courtyard, etc. These all unite to create a city within the City. 


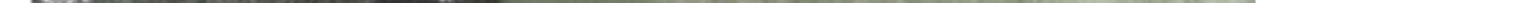




\section{Conclusion}

The literature on the cohousing model demonstrates that a true sense of community and belonging can be achieved by well-defined spatial components and adequate understanding of the social structures of sharing and collaborating. Cohousing, may contribute to answer the needed sense of belonging in view of the fact that it provides relief from possible social isolation tied within conventional building developments while also becoming the catalyst for a new sense of belonging to an existing community, offering an opportunity for simply being together, "living a better life in a more sustainable way". ${ }^{125}$

As a multi-cultural city, Toronto can grow to recognize the common social value of belonging to a community when the advantages of a community-oriented life become more significant and revealing considering that at the present time many families prefer to reside in socially supportive neighborhoods. By understanding the benefits of this residential model, many people interested to experience this lifestyle join the community to 'be with others', acquiring interdependency among inhabitants. With regards to the proposed residential community's design elements, social relationships prospect, and the context, co-housing + offers the potential to become a successful model of an urban infill community. A community that provides privacy, endorses social supports, interacts with the surrounding neighborhood, and gradually endeavors merging to a lasting greater community, fostering a truest sense of belonging.

${ }^{125}$ McCamant, Kathryn. "Design Leader: Kathryn McCamant" 


\section{Bibliography}

Adams, Richard E. "Is Happiness a Home in the Suburbs - the Influence of Urban versus Suburban Neighborhoods on Psychological Health", Journal of Community Psychology, vol. 20, no. 4, pp. 353-372, 1992.

Aragonés, Juan I.; Amérigo, María; Pérez-López, Raquel. "Perception of Personal Identity at Home”, Psicothema Revista De Psicologi, vol. 22, no. 4, pp. 872-879, 2010.

Arendt, Hannah. The Human Condition, $2^{\text {nd }}$ ed., Chicago: University of Chicago Press, 1998.

Aureli, Pier Vittorio. The Possibility of an Absolute Architecture, Cambridge, Mass: MIT Press, 2011.

Bechtel, Robert B.; Churchman, Arza. Handbook of environmental psychology, New York: Wiley Inc., 2002.

Bonta, Juan Pablo. Architecture and its Interpretation: A Study of Expressive Systems in Architecture, London: Lund Humphries, 1979.

Brillembourg, Alfredo; Klumpner, Hubert. Torre David: Informal Vertical Communities, Zurich: Lars Muller Publishers, 2012.

Canadian Cohousing Network

http://www.cohousing.ca

Canada Mortgage and Housing Corporation

http://www.cmhc-schl.gc.ca/en/

City of Toronto

http://www1.toronto.ca/

Cohousing Development Consulting

http://www.cohousingconsulting.ca/

Chiodelli, Francesco; Baglione, Valeria. "Living Together Privately: for a Cautious Reading of Cohousing”, Urban Research \& Practice, vol. 7, no. 1, pp. 20-34, 2014. 
Chodikoff, Ian. "Viewpoint", Canadian Architect, 2007.

Cohen, Sheldon. "Social Relationships and Health", American Psychologist, vol. 59, no. 8, pp. 676-684, 2004.

"Co-housing in the Centre of Ottawa", CBC Radio, February 08, 2014.

http://www.cbc.ca/player/Radio/Local+Shows/Ontario/ID/2435627310/

Coley, Rebekah Levine; Sullivan, William C.; Kuo, Frances E. "Where Does Community Grow? The Social Context Created by Nature in Urban Public Housing", Environment and Behavior, vol. 29, no. 4, pp. 468-494, 1997.

Crouch, Christopher. Modernism in Art, Design and Architecture, New York: St. Martin's Press, 1999.

Debord, Guy. Society of the Spectacle, Detroit: Black \& Red, 1977.

Doyle Street Cohousing

http://www.emeryville-cohousing.org

Dwell

http://www.dwell.com/

Fromm, Dorit. "Seeding Community: Collaborative Housing as a Strategy for Social and Neighborhood Repair", Built Environment, vol. 38, no. 3, pp. 364-394, 2012.

Fromm, Dorit. Collaborative Communities: Cohousing, Central Living, and Other New Forms of Housing with Shared Facilities, New York: Van Nostrand Reinhold, 1991.

Harries, Karsten. "The Need for Architecture", Environmental and Architectural Phenomenology, vol. 20, no. 3, pp. 11-18, 2009.

Harries, Karsten. "Thoughts on a Non-Arbitrary Architecture", Perspecta, vol. 20, pp. 9-20, 1983.

Harries, Karsten. The Ethical Function of Architecture, Cambridge, Mass: MIT Press, 1997.

Hartoonian, Gevork. Architecture and Spectacle: A Critique, Farnham, Surrey, UK, England; Burlington, VT: Ashgate, 2012.

Helamaa, Anna. "The Extended Home: On Design Solutions for Community Oriented Housing", Social Sciences Directory, vol. 2, no. 4, pp. 70-84, 2013. 
Horelli, Liisa. "The Role of Shared Space for the Building and Maintenance of Community from the Gender Perspective - A Longitudinal Case Study In A Neighborhood Of Helsinki", Social Sciences Directory, vol. 2, no. 5, pp. 47-63, 2013.

Hume, Christopher. "Condo Critic: Hope Sails into the Suburbs", The Toronto Star, September 16, 2014.

http://www.thestar.com/life/homes/2010/10/22/condo_critic_hope_sails_into_the_suburbs.ht $\mathrm{ml}$

Jencks, Charles. The Iconic Building, $1^{\text {st }}$ ed., New York: Rizzoli, 2005.

Jencks, Charles. The New Paradigm in Architecture: The Language of Postmodernism, $7^{\text {th }}$ ed., London: Yale University Press, 2002.

Quayside Village Cohousing

https://sites.google.com/site/quaysidevillage/home

Kaiser, Florian G.; Fuhrer Urs. "Dwelling: Speaking of an Unnoticed Universal Language", New Ideas in Psychology, 14(3), 225-236, 1996.

Kaiser, Florian G.; Fuhrer, Urs. "Dwelling: Speaking of an Unnoticed Universal Language", New Ideas in Psychology, vol. 14, no. 3, pp. 225-236, 1996.

King. Peter. Private Dwelling: Contemplating the Use of Housing, London; New York: Routledge, 2004.

Korpela, Salla. "Casa Malta: A Case Study of a Contemporary Co-Housing Project in Helsinki”, Built Environment, vol. 38, no. 3, pp. 336-344, 2012.

Krokfors, Karin. "Co-Housing in the Making", Built Environment, vol. 38, no. 2, pp. 309$314,2012$.

la Rocca, di Greta; Del Nero, Chloe. "Bernard Tschumi: An Architect Has to Be Violent", House Living and Business, April 9, 2010.

Landry, Charles. The Creative City: A Toolkit for Urban Innovators, London: Earthscan Publications, 2000.

Le Corbusier. Towards a New Architecture, New York: Dover Publications, 1986.

Lietaert, Matthieu. "Cohousing's Relevance to Degrowth Theories", Journal of Cleaner Production, vol. 18, no. 6, pp. 576-580, 2010. 
McCamant \& Durrett Architects

http://www.cohousingco.com/

McCamant, Kathryn; Durrett, Charles. Cohousing: A Contemporary Approach to Housing Ourselves, $2^{\text {nd }}$ ed., Berkeley: Ten Speed Press, 1994.

McCamant, Kathryn; Durrett, Charles. Creating Cohousing: Building Sustainable Communities, Gabriola, BC: New Society Publishers, 2011.

McCamant, Kathryn. "Cohousing Communities: A Model for Reinvigorating Urban Neighborhoods", New Village Journal 1: Community Revitalization, no. 1, 1999.

http://www.newvillage.net/Journal/Issue1/1urbaninfill.html

McCamant, Kathryn. "Design Leader: Kathryn McCamant”, Dwell

http://www.dwell.com/video/design-leader-kathryn-mccamant

Meesters, Janine. The Meaning of Activities in the Dwelling and Residential Environment: a Structural Approach in People-Environment Relations, Amsterdam: IOS Press; Delft: Delft University Press, c2009.

Meltzer, Graham. "Cohousing: Verifying the Importance of Community in the Application of Environmentalism", Journal of Architectural and Planning, vol. 17, no. 2, pp. 110-132, 2000 .

Meltzer, Graham. "How Does Cohousing Create Sustainability?", The Cohousing Association of the United States

http://www.cohousing.org/How\%20Does\%20Cohousing\%20Create\%20Sustainability\%3F

Meltzer, Graham. Sustainable Community: Learning from the Cohousing Model, Victoria, BC: Trafford, 2005.

Middleton, D. Scott; Abrahams, Kay. "Cohousing Development: Creating Genuine Communities", Urban Land, vol. 56, no. 9, pp. 32-90, 1997.

Novac, Sylvia; Lapointe, Linda. Analysis of Evictions in the City of Toronto: Co-operative Housing Sector, for the Shelter, Housing, and Support Division, Community and Neighborhood Services Department, City of Toronto, 2004.

Pollio, Vitruvius. Vitruvius: Ten Books on Architecture, New York: Cambridge University Press, 1999.

Ponzini, David; Nastasi, Michele. STARCHITECTURE: Scenes, Actors and Spectacles in Contemporary Cities, Turin; New York: Umberto Allemandi \& C., 2011. 
Pyatok \& Assoc.

http://www.pyatok.com

RealNet

http://www.realnet.ca/

Richins, Marsha L. "Valuing Things: the Public and Private Meanings of Possessions", Journal of Consumer Research, vol. 21, no. 3, pp. 504-521, 1994.

Scarry, Elaine. "On Vivacity: The Difference between Daydreaming and Imagining-UnderAuthorial-Instruction”, Representations, no. 52, pp. 1-26, 1995.

Scotthanson, Chris; Scotthanson, Kelly. The Cohousing Handbook: Building a Palace for Community, Gabriola, B.C.: New Society Publishers, 2004.

Swan's Market Cohousing

http://www.swansway.com/

The Cohousing Association of the United States

http://www.cohousing.org

The Cohousing Company - McCamant \& Durrett Architects

http://www.cohousingco.com/

The Co-operative Housing Federation of Canada

http://www.chfcanada.coop/eng/pages2007/home.asp

The Co-operative Housing Federation of Toronto

http://www.coophousing.com/index.asp

The Sea-to-Sky Green Guide

http://www.seatoskygreenguide.ca/

Thompson, Claire. "Cohousing: the Secret to Sustainable Urban Living?", Grist, July 11, 2012.

http://grist.org/cities/cohousing-the-secret-to-sustainable-urban-living/

Tschumi, Bernard. Architecture and Disjunction, Cambridge, Mass: MIT Press, 1994.

Tschumi, Bernard. Event-cities 3: Concept vs. Context vs. Content, Cambridge, Mass: MIT Press, 2004. 
Vesely, Dalibor. Architecture in the Age of Divided Representation, Cambridge, Mass: MIT Press, 2004.

Vidler, Anthony. Architecture Between Spectacle and Use, Williamstown, Mass: Sterling and Francine Clark Art Institute; New Haven: Distributed by Yale University Press, 2008.

Williams, Jo. "Designing Neighborhood for Social Interaction: The Case of Cohousing", Journal of Urban Design, vol. 10, no. 2, pp. 195-227, 2005.

Williams, Jo. "Predicting an American Future for Cohousing", Futures, vol. 40, no. 3, pp. 268-286, 2008.

WindSong Cohousing Community

http://windsong.bc.ca/homes_environs/index.php

Wong, Tony. "Condo Sales Booming", The Toronto Star, November 15, 2007.

http://www.thestar.com/news/gta/2007/11/15/condo_sales_booming.html 